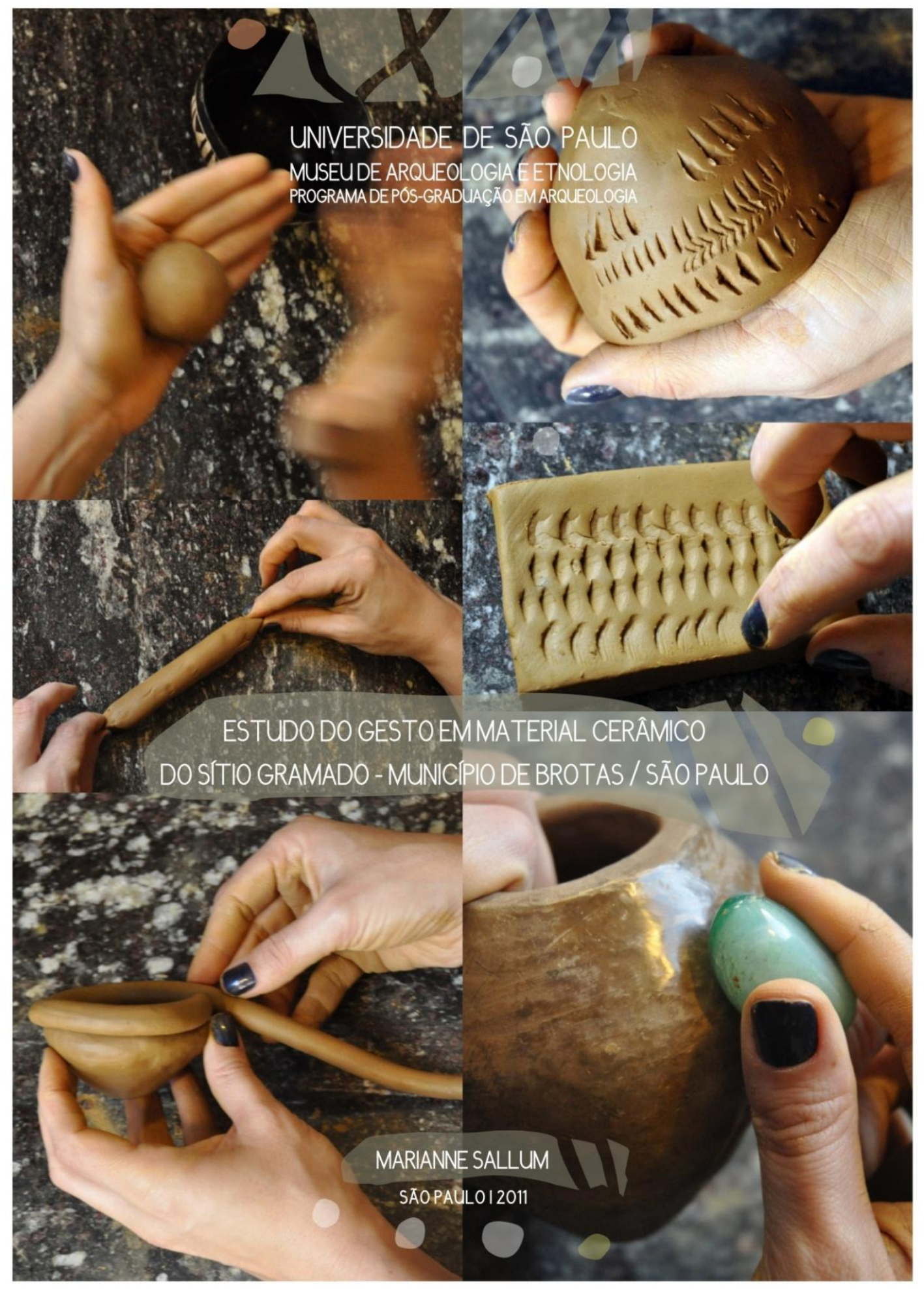




\author{
Universidade de São Paulo \\ Museu de Arqueologia e EtNologia \\ Programa de Pós-Graduação em Arqueologia
}

\title{
Estudo do Gesto em Material Cerâmico do Sítio Gramado - Município de Brotas / São Paulo
}

\section{Marianne Sallum}

Dissertação apresentada ao Programa de Pósgraduação em Arqueologia, do Museu de Arqueologia e Etnologia da Universidade de São Paulo, para obtenção do título de mestre em Arqueologia.

Orientadora: Profa. Dra. Marisa Coutinho Afonso

Linha de pesquisa: Artefato e cultura material: significados e potencialidades

SÃO PAULO

2011 
Marianne Sallum, 2011 Estudo do Gesto em Cerâmicas do Sítio Gramado

Dedico esse trabalho aos meus pais

Estela e Antonio (in memoriam)

e aos tios Carminha e Luiz. 


\section{SUMÁRIO}

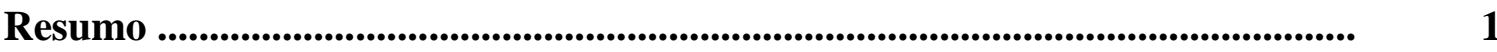

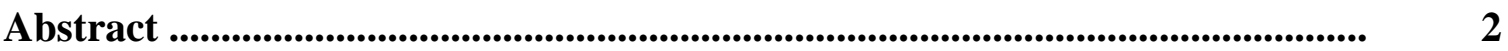

Apresentação ................................................................................................................................. $\quad 3$

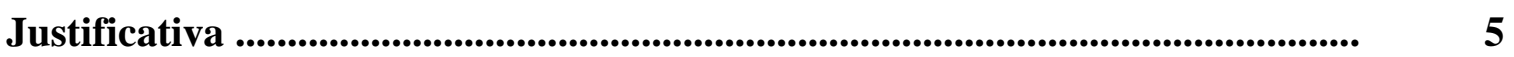

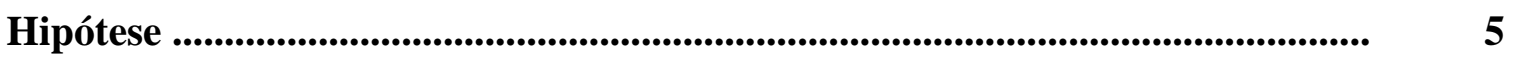

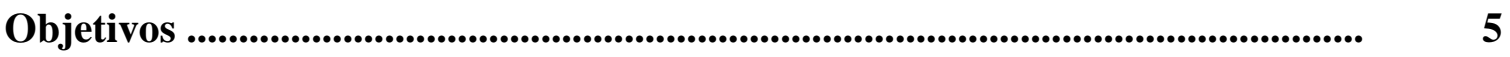

Capítulo 1 - Estudo da região - Município de Brotas, São Paulo - Brasil .......... 7

Capítulo 2 - A metodologia de análise de atributos cerâmicos e a cerâmica do sítio Gramado ............................................................ 26

Capítulo 3 - Cadeia operatória e Experimentação ............................................. $\quad 50$

Capítulo 4 - Análise de vestígios químicos e fluorescência .................................. $\quad 77$

Considerações finais ..................................................................................................... 104

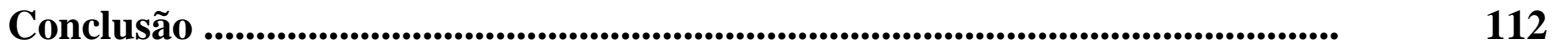

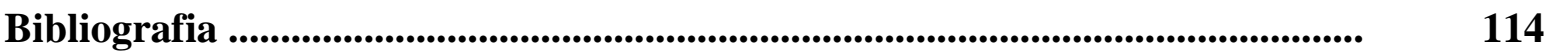




\section{AGRADECIMENTOS}

- À FAPESP, pela bolsa de mestrado concedida;

- À Profa. Dra. Marisa Coutinho Afonso, pela orientação nesses três anos;

- Ao Prof. Dr. José Luis de Morais, por me abrir as portas do MAE-USP;

- Ao Prof. Dr. Grégorio Ceccantini (IB-USP), pela participação na análise e em campo, pelas leituras, revisões e discussões;

- À Dra. Camila Azevedo de Moraes pela confiança no meu trabalho e pelas conversas sobre cerâmica;

- Ao José Paulo Jacob e Dária Elânia Fernandes Barreto (MAE-USP) por auxílios diversos, conversas e informações técnicas;

- À ceramista Máyy Koffler, pela amizade e inúmeros auxílios e consultas de grande expertise em cerâmica;

- À ceramista Suely Massuda, pelos auxílios e conversas sobre cerâmica;

- À Profa. Dra. Águeda Vilhena Vialou e Prof. Dr. Denis Vialou (MNHN-Paris), ensinaram os princípios sobre campo em arqueologia;

- Ao Prof. Dr. Carlos Roberto Appoloni (UEL), pelas conversas e análises de fluorescência de raios-X;

- À Profa. Sonia Hatsue Tatumi (FATEC), pelos ensinamentos e apoio para as datações;

- À Profa. Dra. Teresa Cabrero (UNAM), por me receber em estágio no México e me abrir às portas a diversos pesquisadores;

- Ao Prof. Agustín Ortiz Butrón (UNAM), pelos ensinamentos sobre vestígios de análises químicas e discussões;

- Ao Prof. Dr. Carlos Lazcano Arce (UNAM), pela amizade, conversas sobre arqueologia mexicana, além de experiência de campo em arqueologia em Tlaxcala - México;

- Ao Prof. Dr. Rodrigo Liendo Stuardo (UNAM), pela oportunidade de escavar em Chinikihá - Palenque, México;

- Ao Prof. Dr. Fernando A. Carrizona Monfort, do Museo del Templo Mayor - INAH (México) pelo acesso irrestrito aos materiais cerâmicos dos Astecas;

- Ao Prof. Eládio Terreros Espinosa do Museo del Templo Mayor - INAH (México), pelas conversas sobre cerâmica; 
- Ao SESC-SP, pelo afastamento do trabalho que viabilizou esta pesquisa;

- À Rede Macrouniversidades e Banco Santander, pela bolsa que permitiu meu estágio na UNAM e visitas a inúmeros sítios arqueológicos do México;

- À Zanettini Arqueologia, pela oportunidade de pesquisa com réplica de cerâmica arqueológica;

- À A3 Comunicação pelo apoio em design da capa;

- À Andréa Pedro, pela amizade, por inúmeros auxílios e socorros gráficos e computacionais;

- À Andréa Catropa, pela amizade e discussões;

- À Dna. Emília, pela amizade;

- À minha família Estela, Patrícia, Suzanne e Beatriz, por tudo...;

- Ao Greg, pelo carinho, apoio, incentivo incondicionais, sem os quais essa dissertação não teria sido possível. 
"Jarra de vidro, cesta de vime, huipil de algodão, caçarola de madeira: coisas bonitas, não a despeito de, mas graças a sua utilidade. A beleza lhes vem por acréscimo, como o perfume e a cor das flores. Sua beleza é inseparável de sua função: são bonitas porque são úteis. Os objetos de artesanato pertencem a um mundo anterior à separação entre o útil e o belo. No artesanato há um contínuo vaivém entre utilidade e beleza; esse vaivém tem um nome: prazer. As coisas dão prazer porque são úteis e belas".

Paz, Octavio. Ensaio Ver e usar: arte e artesanato, In: Convergências - ensaios sobre arte e literatura. São Paulo: Ed. Rocco, 1991. 


\section{Resumo}

Esta dissertação apresenta um estudo aprofundado do material cerâmico do sítio Gramado situado no município de Brotas, Vale Médio do Rio Tietê, SP, acondicionado no Museu de Arqueologia da USP desde 1994, associado à tradição Tupiguarani. A pesquisa envolveu diversas abordagens metodológicas e técnicas: análise da distribuição das peças cerâmicas no sítio, mapeamento de densidade; análise de atributos cerâmicos pautada na metodologia de pesquisa de literatura pretérita; análise de vestígios químicos e fluorescência de raios-X, com o intuito de compreender aspectos relacionados aos pigmentos químicos, pasta cerâmica e possíveis atribuições de uso dos fragmentos cerâmicos; reconstituição da cadeia operatória, desde a escolha de materiais até a definição de formas e traços, identificação de pigmentos, aplicação de engobo, processo de secagem e tempo/temperatura de queima de uma peça. Todas as análises tiveram como eixo norteador a Experimentação como forma de compreender atitudes corporais impressas na argila, partindo de escolhas tecnológicas e artísticas do grupo estudado. A análise de distribuição mostrou que ao redor de onde foi encontrada a urna funerária que levou à descoberta do sítio, há grandes concentrações de fragmentos (centenas por $\mathrm{m}^{2}$ ) que demonstram que o sítio é promissor para novas escavações. A análise de tributos cerâmicos mostrou grande diversidade de formas, decorações, espessuras, que serviram de base para a abordagem da experimentação. A dominância foi de decorações plásticas, mas com pinturas claramente associadas à tradição tupiguarani. A análise de pinturas reproduziu padrões geométricos, ricos em fundos brancos, faixas transversais vermelhas e rica ornamentação em preto. As pesquisas com fluorescência de raios-X indicaram que as pastas são relativamente homogêneas e que as pinturas são de natureza mineral. O conjunto de análises mostrou que as pinturas foram aplicadas pela técnica do engobo, ou seja, pigmentação mineral antes da queima, quando as peças atingem o ponto de couro. A análise de atributos e a experimentação permitiram também reconstruir os passos da cadeia operatória e esclarecer que as pinturas eram aplicadas antes da queima e que as decorações corrugadas também estão associadas a gestos naturais para a união de roletes e não são, necessariamente, intenções decorativas. A experimentação mostrou que a cerâmica necessita de um tempo preciso para a aplicação de pinturas e que a preparação das peças exige grande domínio da técnica, bem como condições sociais adequadas para a produção de peças, sua secagem e queima. Assim a experimentação corroborou a hipótese de que a cerâmica expressa também características culturais e sociais. Este trabalho demonstrou que o estudo do gestual reflete, não somente questões individuais pertinentes ao artesão, mas também as relações sociais e organizacionais de uma sociedade marcadas no material cerâmico.

Palavras-chave: CERÂMICA TUPIGUARANI, EXPERIMENTAÇÃO, GESTO, ARQUEOLOGIA PAULISTA, BROTAS, SÍTIO GRAMADO, VALE DO TIETÊ, CADEIA OPERATÓRIA. 


\begin{abstract}
This dissertation presents a deep study on pottery material related to tupiguarani tradition from Gramado archeological site, located at Brotas county, middle Tietê valley, São Paulo State, Brasil. These materials were deposited in University of São Paulo Museum of Archeology and Ethnology (MAE-USP), since 1994. This research used several approaches and techniques, including distribution analysis, density mapping, ceramic attribute analysis, chemical vestiges analysis, X-ray fluorescence, experimentation approach and research in previous literature, all them aiming to understand features related to pottery, possible uses, reconstitution of "chaine operatoire" (operating chain). The analysis begins at material choice, reaching pigment identification, engobe application, drying process, temperature and time burning process. All analysis had as leading axis the "experimentation" approach, as a way for comprehension of body attitude printed in clay. This analysis started from artistic and technological choices from the studied population. The spatial distribution analysis showed that, where the funerary vessel it was found (that lead to the discovery of the archeological site). There were some interesting ceramic fragment concentrations (hundreds per square meter) that demonstrate that this site is very rich and promising for new excavations. The ceramic attribute analysis showed a broad diversity of forms, decorations, thicknesses and served as basis for experimentation research. It was found the domination of plastic decorations, but many paintings, clearly related to "tupiguarani" tradition. The painting analysis reproduced geometric patterns, rich in white backgrounds, red transversal rows, and rich in black drawings. The $\mathrm{x}$-ray fluorescence analysis showed that ceramic paste was relatively homogeneous and that paintings had mineral nature. The analysis showed that paintings were set by the engobe technique, what means that mineral stains were applied before burning, when ceramics was reaching a certain humidity level called "ponto de couro" (literally leather point). That point is the humidity that the piece is suitable to receive engobe and fix it so after drying is suitable to go to oven. The attribute analysis and experimentation approach allowed reconstructing steps of a plausible operating chain, clarifying that painting were applied before burning and corrugate decoration was associated to natural gests used when connecting clay rolls, not necessary related to decorative motivation. The experimentation approach showed that the ceramic pieces need a precise time for painting application (engobe) and that the piece fabrication demands a deep domination of pottery techniques, as well as particular social conditions, suitable for pottery production, correct dying and proper controlled burning. So the experimentation approach has corroborated the idea that the pottery also express cultural and social features, expressed in clay. This work demonstrated that the gesture study reflects, not only, individual aspects, but as well social relations, organizational aspects of a society, printed in burned clay.
\end{abstract}

Key-words: TUPIGUARANI CERAMICs, EXPERIMENTATION, GESTURE STUDY, ARCHAEOLOGY OF SÃO PAULO STATE, BROTAS, GRAMADO ARCHEOLOGICAL SITE, TIETÊ VALLEY, OPERATING CHAIN. 


\section{Apresentação}

Este trabalho consiste na análise de atributos, experimentação de etapas da cadeia operatória e análise de vestígios químicos de 5.000 fragmentos cerâmicos associados à tradição Tupiguarani do sítio Gramado na Fazenda Aparecida do Gramado, município de Brotas - São Paulo. A coleta de material ocorreu em 1994 sob coordenação da Prof ${ }^{a}$. Dra. Marisa Coutinho Afonso do Museu de Arqueologia e Etnologia da Universidade de São Paulo e com apoio financeiro da Prefeitura de Brotas.

O enfoque da pesquisa foi o estudo do gesto do artesão, compreendido como reflexo de atitudes que refletem normas sociais. Para tanto, foram realizadas atividades sistemáticas de experimentação com material cerâmico, desde a escolha de materiais (argila adequada, instrumentos, antiplástico), técnica de confecção, secagem até o processo de queima e pósqueima (uso, quebra e descarte).

Este trabalho teve como base teórica as noções de técnicas corporais de Mauss (1974), bem como os trabalhos de Coles (1973), Skibo (1992, 2008), Skibo e Schiffer (2008) e LeroiGourhan (1990). Vale ressaltar a grande contribuição tanto de Mauss, como Leroi-Gourhan no que diz respeito ao entendimento dos atos individuais (comportamento maquinal) como conseqüências de processos sociais de aprendizagem.

A dissertação apresenta-se dividida em quatro capítulos seguida de considerações finais e conclusão, relacionando as análises dos capítulos anteriores. Os capítulos foram planejados como artigos independentes, por esse motivo cada um deles tem sua própria introdução e a dissertação não tem uma introdução central.

O capítulo 1 apresenta a caracterização da área de estudo e um histórico das pesquisas de campo e laboratório realizadas no sítio Gramado desde 1994, bem como um mapa de densidade e ocorrência de material cerâmico no sítio, evidenciando a grande quantidade de material em superfície e em sub-superfície. Além disso, apresenta uma cronologia dos estudos sobre os sítios cerâmicos no Estado de São Paulo

O capítulo 2 mostra o resultado da análise sistemática de atributos cerâmicos de 4.332 fragmentos. A classificação enfocou aspectos quantitativos e qualitativos e foi baseada nas metodologias de Rye (1981), La Salvia \& Brochado (1989), Skibo (1992), Moraes (2007) e 
Gomes (2002). Foram realizados estudos de desenho dos fragmentos com decoração plástica, além de relevés das pinturas e estudos dos padrões estilísticos.

No capítulo 3 é apresentada uma análise detalhada do processo de confecção de um pote cerâmico, desde a escolha de materiais até o processo de queima, tendo como eixo norteador o estudo do gestual para compreender aspectos de escolhas tecnológicas. A teoria de estudo baseou-se um Mauss (1974), Skibo e Schiffer (2008).

No capítulo 4 são apresentados os resultados provenientes da análise de vestígios químicos realizada no Laboratório de Prospecção Arqueológica da Universidad Nacional Autónoma de México, além de análise de pasta cerâmica e pigmento realizadas no Laboratório de Conservação do Museu de Arqueologia e Etnologia da Universidade de São Paulo (MAE-USP), utilizando os métodos do Laboratório de Física Nuclear Aplicada do Departamento de Física da Universidade Estadual de Londrina.

Para finalizar, os dados apresentados nos quatro capítulos iniciais são retomados, relacionando-os entre si e construindo conclusões lógicas e dedutivas a partir das discussões de cada um deles. 


\section{JUSTIFICATIVA}

A cerâmica do sítio Gramado é uma coleção relevante do acervo do Museu de Arqueologia e Etnologia da Universidade de São Paulo e que ainda não havia sido estudada. O grande número de fragmentos coletados e a grande diversidade de tipos decorativos demonstram tratar-se de uma amostra rica para estudos com experimentação. Além disso, existem poucas pesquisas sistemáticas de experimentação com material cerâmico no Brasil. Considerando o exposto acima: a relevância da coleção, diversidade do material e as poucas pesquisas com experimentação, decidiu-se testar a seguinte hipótese e alcançar os seguintes objetivos.

\section{HIPÓTESE}

A hipótese de trabalho foi elaborada considerando as afirmações de dois autores:

"Noções de técnicas corporais - esses atos expressos pelo individuo no objeto não somente por suas escolhas pessoais, mas como reflexo da sua educação, da sociedade da qual ele faz parte, e do lugar que ele nela ocupa." (Mauss, 1974).

“A experimentação como forma de entender os hábitos de uma sociedade a partir de atitudes corporais impressas na argila, e a fim de apontar o entendimento e as relações entre a cultura material, o comportamento humano e o ambiente (Skibo, 1992).

A partir das considerações acima, foi possível formular a seguinte hipótese:

O estudo sistemático do gesto, a partir da experimentação, permite identificar aspectos comportamentais de uma sociedade.

\section{OBJETIVOS}

\section{Objetivos Gerais:}

- Analisar cerca de 5.000 fragmentos cerâmicos coletados no sítio Gramado, utilizando a experimentação como base de trabalho, com o intuito de remontar a cadeia operatória, desde a escolha de materiais, forma, traços, queima e por fim, a utilidade a que se destinava o pote. 
- Entender a partir de fragmentos cerâmicos, atitudes corporais impressas na argila que revelem hábitos sociais.

- Estabelecer o entendimento e as relações entre a cultura material e o comportamento humano.

- Compreender as etapas da cadeia operatória.

\section{Objetivos específicos:}

- Estabelecer protocolo de análise com parâmetros objetivos e planilha padronizada de atributos cerâmicos.

- Estudar estilos de decoração e técnicas de construção de um pote.

- Analisar aspectos relacionados à secagem e queima da cerâmica.

- Analisar substâncias químicas das cerâmicas - a pintura e pasta cerâmica por fluorescência de raios-X, bem como análise de vestígios.

- Remontar as peças, quando possível.

- Construir réplicas de cerâmica arqueológica para atividades de educação em museus.

- Registrar com fotografia o processo de experimentação. 


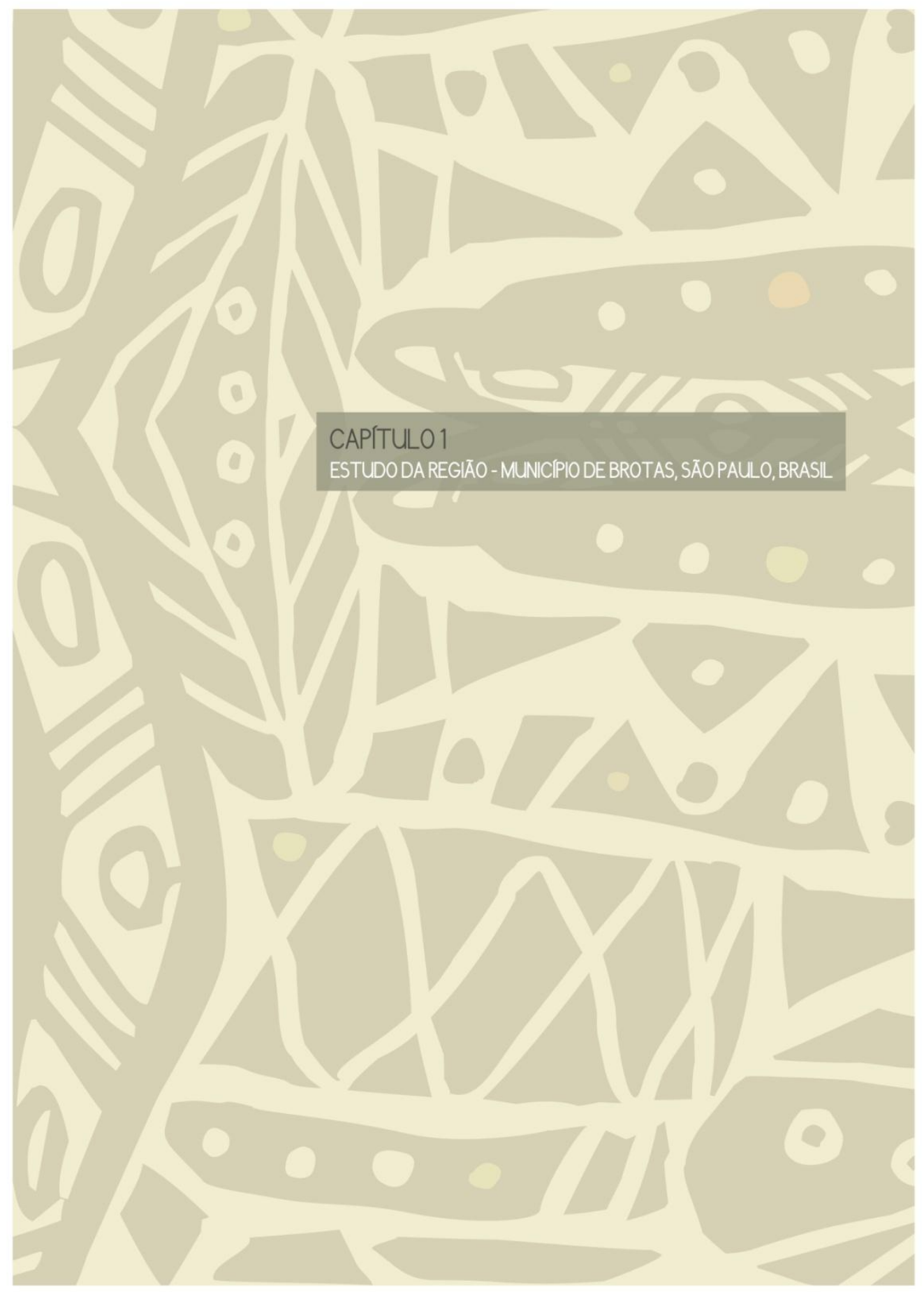




\section{SUMÁRIO}

\section{CAPÍTULO 1 - Estudo da região - Município de Brotas, São Paulo - Brasil.}

1.1 Região de Estudo

1.2 Histórico de Brotas

1.3 Cronologias dos estudos sobre sítios cerâmicos no Estado de São Paulo

1.4 Etapas de pesquisa

1.5 Distribuição da cerâmica no sítio Gramado

1.6 Conclusão

\section{Figuras}

1.1 Localização do município de Brotas no Estado de São Paulo

1.2 Imagem de satélite da região de Brotas

1.3 Imagem de satélite do sítio Gramado

1.4 Rio Jacaré Pepira no século XX

1.5 Trabalho de escavação I

1.6 Trabalho de escavação II

1.7 Trabalho de escavação III e laboratório

1.8 Diagrama de distribuição geral dos fragmentos cerâmicos

1.9 Diagrama de distribuição dos fragmentos cerâmicos em superfície

1.10 Sítio Gramado em visita de 2009 (1)

1.11 Sítio Gramado em visita de 2009 (2)

\section{Tabelas}

1.1 Histórico das pesquisas no sítio Gramado

1.2 Coordenadas geográficas 


\subsection{Região de Estudo}

O município de Brotas está localizado na Região Sudeste do Brasil, na área central do Estado de São Paulo e a noroeste da capital (Figura 1.1). Atualmente o município possui uma área de 1.101,39 km² e conforme o primeiro resultado do Censo 2010 possui uma população de 21.580 habitantes (IBGE, 2010).

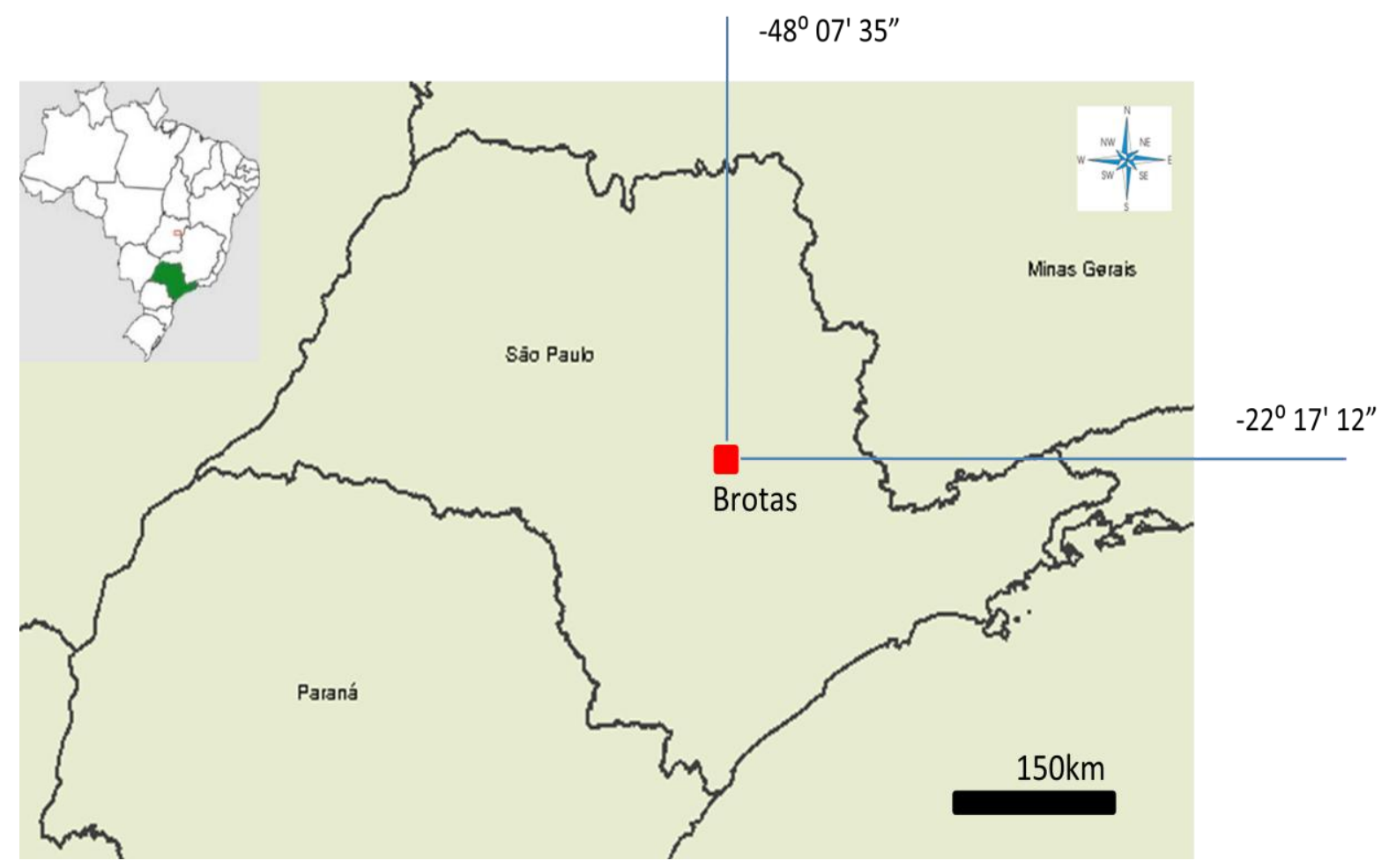

Figura 1.1 - Localização do município de Brotas no Estado de São Paulo.

Na figura 1.2 observa-se a posição relativa da Fazenda Aparecida do Gramado com o Rio Jacaré Pepira e a distância do centro urbano do município. 


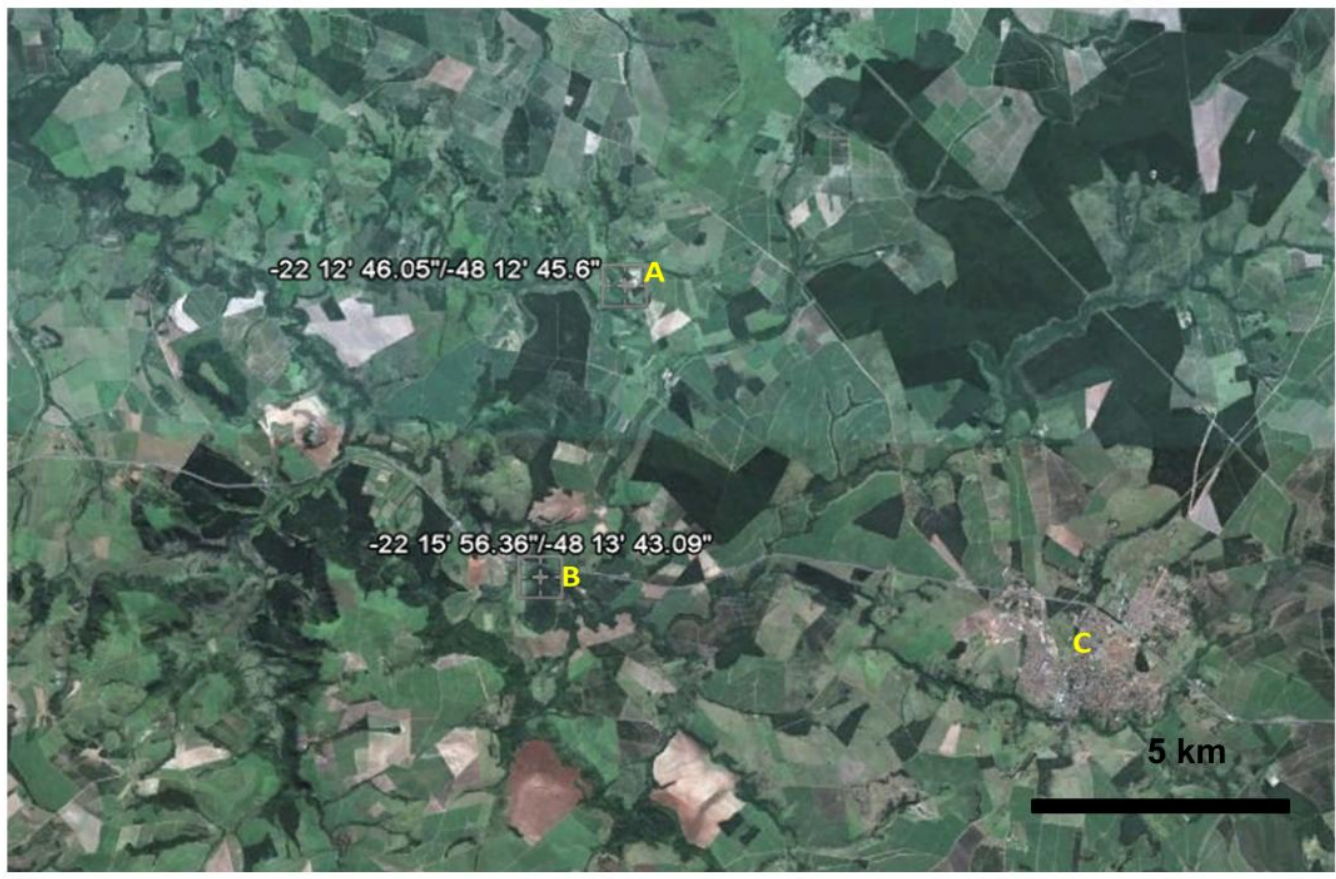

Figura 1.2 - Imagem de satélite da região de Brotas. A - sítio Gramado; B - Rio Jacaré Pepira, C - Área urbana. Imagem obtida pelo sistema Google Earth (Maplink Tele Atlas, 2010).

Na figura 1.3 observa-se a distância relativa entre a sede da Fazenda Aparecida do Gramado e o local exato onde se encontrou material arqueológico.

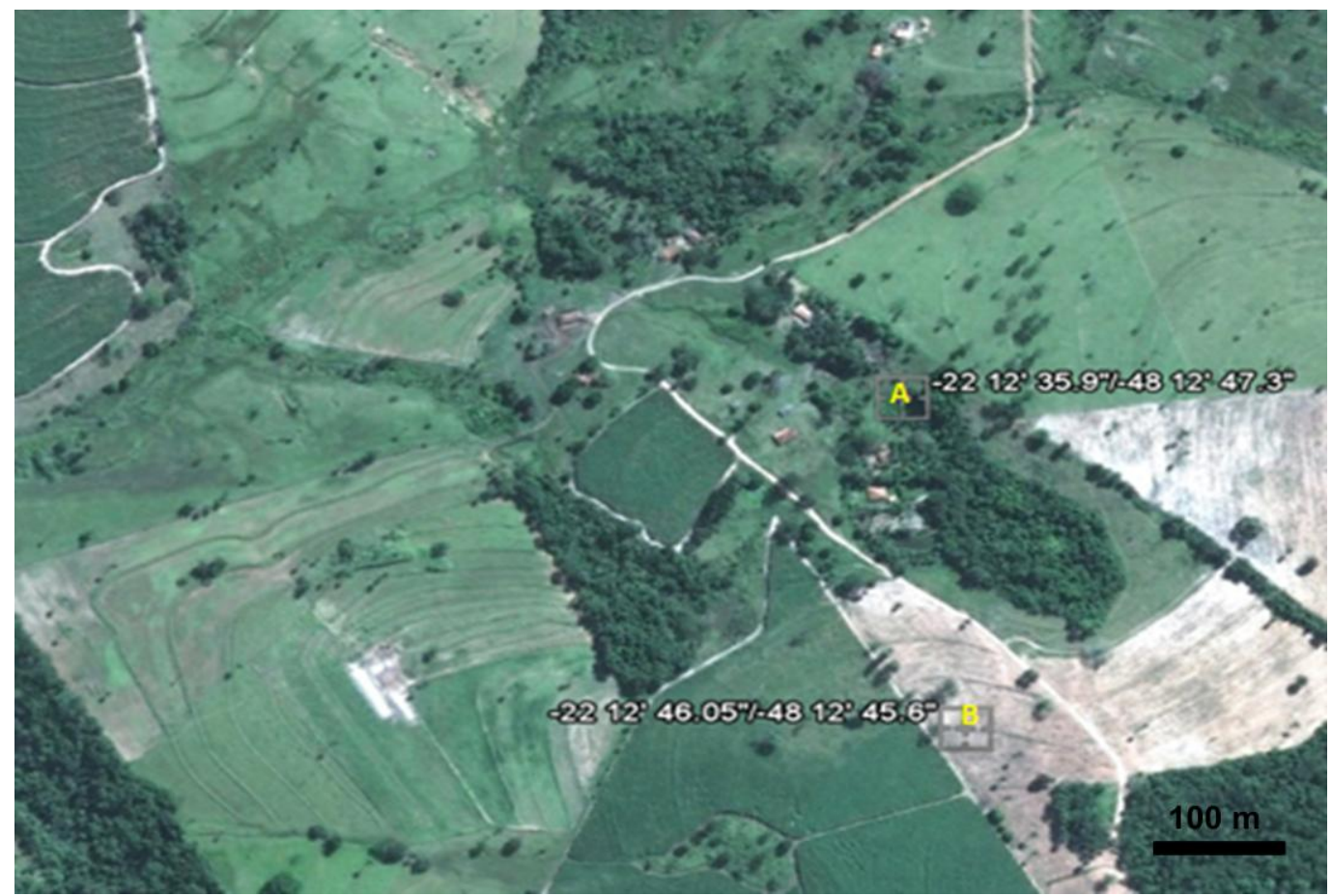

Figura 1.3 - Imagem de satélite do sítio Gramado. A - Fazenda Aparecida do Gramado; B - Sítio Gramado. Imagem obtida pelo sistema Google Earth (Maplink Tele Atlas, 2010). 


\subsection{Histórico de Brotas}

O começo do povoamento de "Aracoara" (hoje município de Brotas) deu-se com a vinda de José Ribeiro da Silva Reis, ao final do século XVIII. Reis mudou-se de São Paulo para o sertão, tornando-se proprietário de sesmarias da região. Na época, Brotas era um distrito, fazia parte de Araraquara e, somente em 1859, se tornaria uma vila. O povoado que se formou às margens do rio Jacaré Pepira (afluente do rio Tietê) era conhecido como Fazenda Velha - nome da antiga propriedade de Reis. Em 1840, seus herdeiros construíram uma capela para Nossa Senhora das Dores de Brotas e vem deste fato à hipótese mais provável sobre a origem da denominação do município (IBGE, 2010). Ao longo da história Brotas recebeu vários outros nomes, como: Brotas de Olho/Brotas d’água, Brotas de broto de capim/mato; Bolota (bolos característicos da região).

No século XIX, viveu um período de grande prosperidade econômica graças à expansão do café e à construção de ferrovias, recebendo imigrantes, principalmente italianos, que vieram em busca de trabalho. Porém, o início da I Guerra Mundial (1914) causou importante declínio dos preços do café e a decadência das plantações da região. Com isso o município de Brotas viuse obrigado a investir em agropecuária e, por consequiência, iniciou-se uma saída em massa de trabalhadores para os grandes centros urbanos (Castro, 2011).

Na figura 1.4 observa-se uma foto do Rio Jacaré Pepira nos anos de 1940 do século XX.

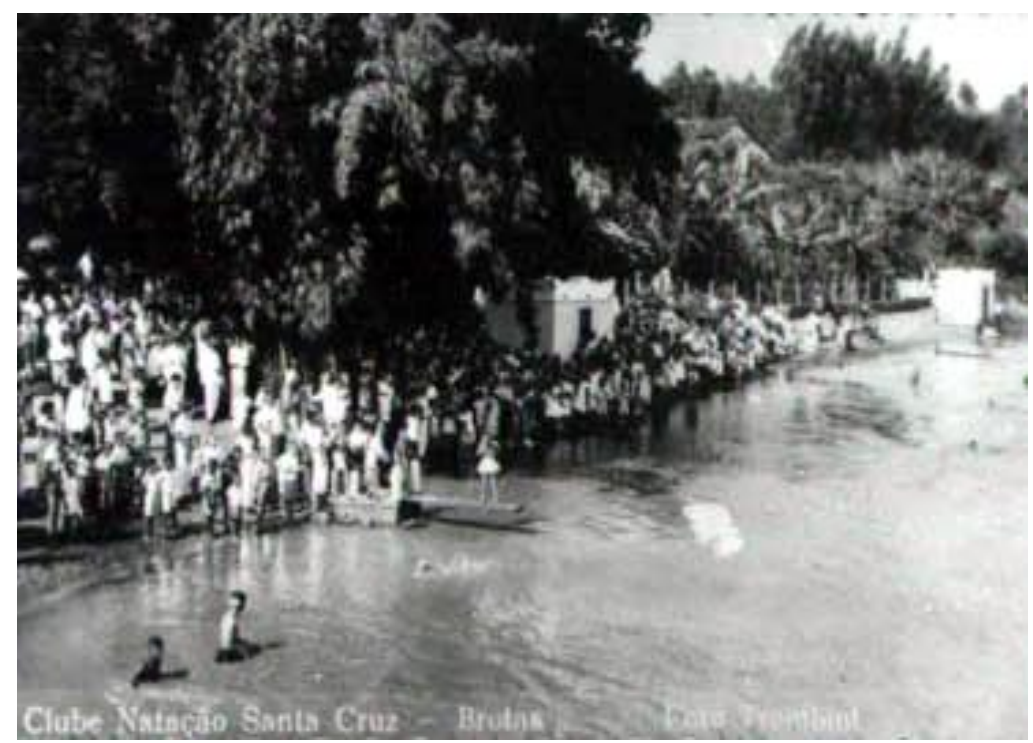

Figura 1.4. Atividades do clube de natação Santa Cruz no Rio Jacaré Pepira, em meados dos anos 40 do século XX (Castro, 2011). 
Atualmente, a economia local baseia-se na plantação de cana de açúcar e laranja, bem como em atrativos de ecoturismo e hotelaria.

No que diz respeito à vegetação, divide-se entre Mata Atlântica, Cerrado em várias fisionomias como cerradões, além de matas de galerias, que seguem os cursos d’água. Atualmente, grande parte da vegetação nativa encontra-se substituída pela agropecuária, porém ainda restam pequenas áreas preservadas.

\subsection{Cronologias dos estudos sobre sítios cerâmicos no Estado de São Paulo}

Os primeiros estudos sistemáticos em São Paulo foram realizados por Luciana Pallestrini na década de 60 do século XX, cujas primeiras pesquisas foram sobre os sítios: Fonseca (Itapeva), Jango Luís e Barreiro dos Italianos (Angatuba). Destaca-se a incorporação por Pallestrini da interdisciplinaridade no estudo arqueológico (Afonso, 2005).

Segundo pesquisas de Maranca et al. (1994), Miller (1972) e Afonso (2005) na Bacia do Rio Tietê foram encontrados, desde a década de 1960, sítios cerâmicos associados à tradição Tupiguarani.

Na década de 80 do século XX, mais precisamente na região da Bacia do Rio Mogi Guaçu, a Universidade de São Paulo realizou pesquisa em três momentos distintos. Num deles foi no sítio cerâmico Franco de Godoy por Pallestrini (1979-81). Já Caldarelli e Neves (1982) pesquisaram quatro aldeias ceramistas da Bacia do rio Mogi Guaçu, dentro do Projeto "Programa de Pesquisas Arqueológicas no vale médio do Rio Pardo, São Paulo”. Enquanto Morais (1985), com o realizaram pesquisa nos municípios de Mogi Guaçu, Mogi Mirim e Itapira.

Nos anos de 1998 e 1999, a Universidade de São Paulo executou o projeto “Arqueologia da Paisagem: Cenas do Paranapanema Paulista (da pré-história ao ciclo do café)", no qual foram identificados vários sítios, entre eles: Campina e Roque e Branco, conforme artigo de Morais (1999).

Robrahn-González (1996) realizou um trabalho de classificação de sítios cerâmicos no Estado de São Paulo encontrados até o ano de 1997, dividindo por tradições cerâmicas. São elas:

- Tradição Tupiguarani: considerada a mais antiga e com vestígios por todo o Estado de São Paulo. A região sul do Estado como zona de fronteira entre os grupos Guarani, ao sul e Tupinambá, ao norte.

- Tradição Itararé: sítios na porção sul. O Estado de São Paulo seria o limite setentrional desta tradição. 
- Tradição Aratu-Sapucaí: sítios na região norte e centro-oeste e nordeste do Brasil.

Afonso (2002) a partir do projeto "Resgate Arqueológico dos Sítios Água Branca, Lambari I e Lambari II, Municípios de Casa Branca e Mococa - SP”, investigou os sítios cerâmicos Água Branca e Lambari II, norte do Estado de São Paulo. O resultado da pesquisa encontra-se no artigo de Afonso \& Moraes (2006).

Zanettini (2005) classificou vários sítios cerâmicos pré-coloniais na cidade de São Paulo: Perus, Itapevi, Jardim Princesa e Jaraguá e urnas funerárias no Brás, Penha, Brooklin e Mooca.

Segundo Afonso (2005) com relação aos sítios associados à tradição Aratu, destacam-se as pesquisas de Alves \& Cheuiche-Machado; Alves \& Calleffo e Fernandes no sítio Água Limpa; Maranca et al. (1994) no sítio Maranata; Robrahn-González, (1998) no sítio Água Vermelha II e Gomes (2002) no sítio Caçapava I.

Apesar dos inúmeros estudos de sítios arqueológicos de São Paulo, observam-se ainda lacunas no que diz respeito às áreas de interação e zonas de fronteirais culturais dentro do Estado.

\subsection{Etapas da pesquisa}

As pesquisas no sítio Gramado iniciaram em 1994 com uma prospecção arqueológica na Fazenda Aparecida do Gramado - município de Brotas. O material coletado nessa etapa está acondicionado na reserva técnica do Museu de Arqueologia e Etnologia da Universidade de São Paulo. A pesquisa foi dividida por etapas conforme tabela 1.1. 
Tabela 1.1 - Histórico das pesquisas sobre o sítio Gramado.

\begin{tabular}{|c|c|c|}
\hline ETAPAS & ATIVIDADES & Pesquisador/Equipe \\
\hline $1^{\mathrm{a}}$ campo & $\begin{array}{l}1994-\text { Prospecção e coleta de } \\
\text { material arqueológico. }\end{array}$ & $\begin{array}{ll}\text { Equipe do } & \text { Museu de } \\
\text { Arqueologia e } & \text { Etnologia }\end{array}$ \\
\hline $\begin{array}{l}1^{\mathrm{a}} \\
\text { laboratório }\end{array}$ & $\begin{array}{l}\text { - Ficha de atributos cerâmicos. } \\
1996 \text { a } 1998\end{array}$ & $\begin{array}{l}\text { Goulart - bolsista de iniciação } \\
\text { científica do CNPq, sob a } \\
\text { coordenação da Profa. Dra. } \\
\text { Marisa Coutinho Afonso } \\
\text { (MAE/USP). }\end{array}$ \\
\hline $\begin{array}{l}2^{\mathrm{a}} \\
\text { laboratório }\end{array}$ & $\begin{array}{l}2006 \text { - análise de atributos cerâmicos } \\
\text { com base em planilha elaborada por } \\
\text { Moraes (2007), além da confecção de } \\
\text { relevés da cerâmica pintada. }\end{array}$ & $\begin{array}{l}\text { Marianne Sallum e Daniela } \\
\text { Maria Alves (MAE/USP). }\end{array}$ \\
\hline 2008 & $\begin{array}{l}\text { Mestrado no Museu de Arqueologia } \\
\text { e Etnologia - MAE. }\end{array}$ & $\begin{array}{l}\text { Marianne Sallum sob a } \\
\text { orientação da Profa. Dra. } \\
\text { Marisa Coutinho Afonso } \\
\text { (MAE/USP). }\end{array}$ \\
\hline $2^{\mathrm{a}}$ campo & $\begin{array}{l}2009 \text { - Visita ao sítio Gramado a fim } \\
\text { de entrevistar os moradores e } \\
\text { verificar a situação do sítio. }\end{array}$ & $\begin{array}{l}\text { Marianne Sallum e Prof. Dr. } \\
\text { Gregório Ceccantini. }\end{array}$ \\
\hline
\end{tabular}

\section{Campo- 1994}

Em 1993, a pedido da Prefeitura Municipal de Brotas, foi realizada uma visita da equipe do Museu de Arqueologia e Etnologia (MAE) da Universidade de São Paulo à Fazenda Aparecida do Gramado. A visita tinha por objetivo constatar a possibilidade da ocorrência de um sítio arqueológico, tendo em vista que em 1988, durante a realização de trabalhos agrícolas, foi encontrada uma urna cerâmica com restos esqueletais. A urna foi retirada e depois recolocada no mesmo lugar pelo proprietário. 
A existência do sítio arqueológico foi confirmada pela equipe do MAE após vistoria em 26 de novembro de 1993. O trabalho de campo patrocinado pela Prefeitura Municipal de Brotas aconteceu no período de 19 de setembro a 02 de outubro de 1994, quase um ano após a confirmação do sítio. Neste período, houve um acordo com proprietário para não plantar no local até a finalização da pesquisa arqueológica e a Prefeitura o ressarciu dos prejuízos financeiros.

Em 1994, o trabalho de campo aconteceu sob a coordenação da Prof ${ }^{a}$. Dra. Marisa Coutinho Afonso e uma equipe do MAE composta por: Prof. Eduardo G. Neves (arqueólogo MAE), Prof. Levy Figuti (arqueólogo - MAE), Silvia Cristina M. Piedade (técnica em arqueologia), José Paulo Jacob (técnico em arqueologia), Ghislaine Lamounier (geógrafa MAE), Daniela Magalhães Klokler (aluna - MAE), Luciane Kamase (estagiária - MAE), Marcelo Afonso (estagiário - MAE), Robson Santiago (estagiário - MAE), Tamima Mourad (estagiária - MAE), Severino L. de Pontes (motorista - MAE), além de dois trabalhadores braçais.

A cerâmica do sítio Gramado foi datada por termoluminescência em $190 \pm 20$ anos BP (FATEC, número LVD 592).

O projeto desde o seu início se propunha a estabelecer - do ponto de vista científico e educacional - um diálogo constante com a comunidade local. Promovendo o envolvimento de alunos/estagiários do município em várias etapas do processo de pesquisa. Foram organizadas aulas pela coordenadora cultural da prefeitura, diretora e professores que foram ministrados pela Profa. Dra. Marisa Coutinho Afonso (MAE). O público alvo era de alunos de $1^{\circ}$ e $2^{\circ}$ graus de várias escolas da região, tendo a complementação de visitas monitoradas ao sítio arqueológico. As atividades ocorreram de 23 a 27 de outubro de 1995. Além disso, outras aulas/palestras foram realizadas para a comunidade em geral, com o intuito de tornar públicos os achados arqueológicos e mostrar a importância do patrimônio cultural do município. Ressalta-se, também que houve a divulgação dada pela mídia local - TV Globo e o jornal "Notícias do Interior".

\section{Área de atividade}

Para o trabalho de prospecção arqueológica, estabeleceram-se alguns critérios para coleta de material, uma vez que se evidenciou muita cerâmica em superfície e conhecia-se o local exato onde foi encontrada uma urna funerária (informação oral). Estabeleceram-se sete pontos de sondagem perto da urna, com a finalidade de conhecer a profundidade da camada arqueológica e a delimitação do sítio em sub-superfície. A sondagem atingiu uma profundidade de $80 \mathrm{~cm}$, 
evidenciando muita cerâmica arqueológica. Foram delimitadas áreas de coleta superficial sistemática, divididas por quadras de A - U e numeração de 1 - 22, sem precisar o local exato de cada fragmento dentro da quadra. Estabeleceu-se, também, uma área somente para coleta seletiva de bordas e cerâmica com decoração. Dessa investigação não havia informações disponíveis sobre georeferenciamento.

Nas figuras 1.5, 1.6 e 1.7 temos diversas etapas do trabalho de prospecção, escavação e laboratório realizados no ano de 1994.
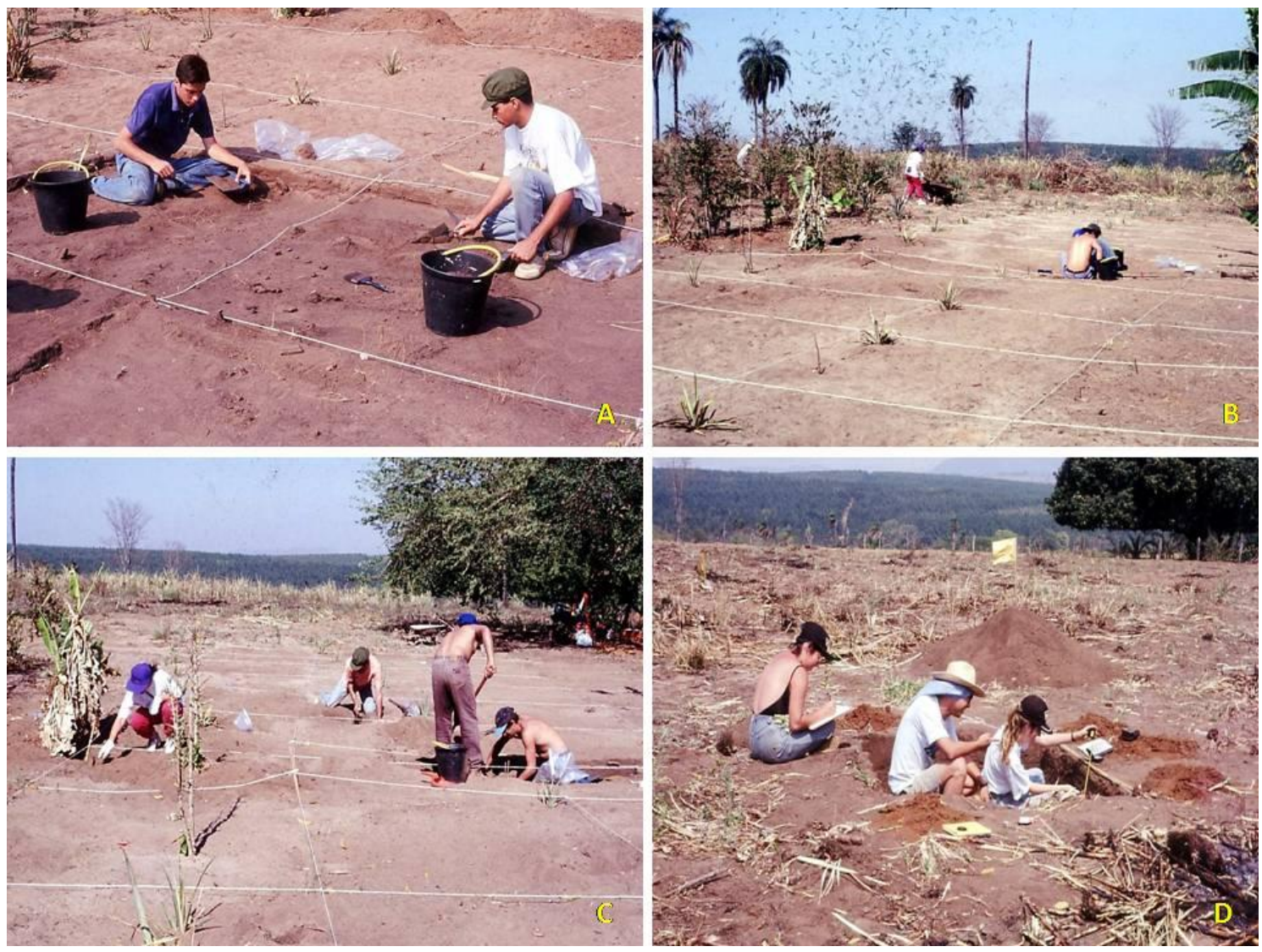

Figura 1.5 - Trabalho de escavação I. A - D - Divisão por quadras. 
Marianne Sallum, 2011

Estudo do Gesto em Cerâmicas do Sítio Gramado

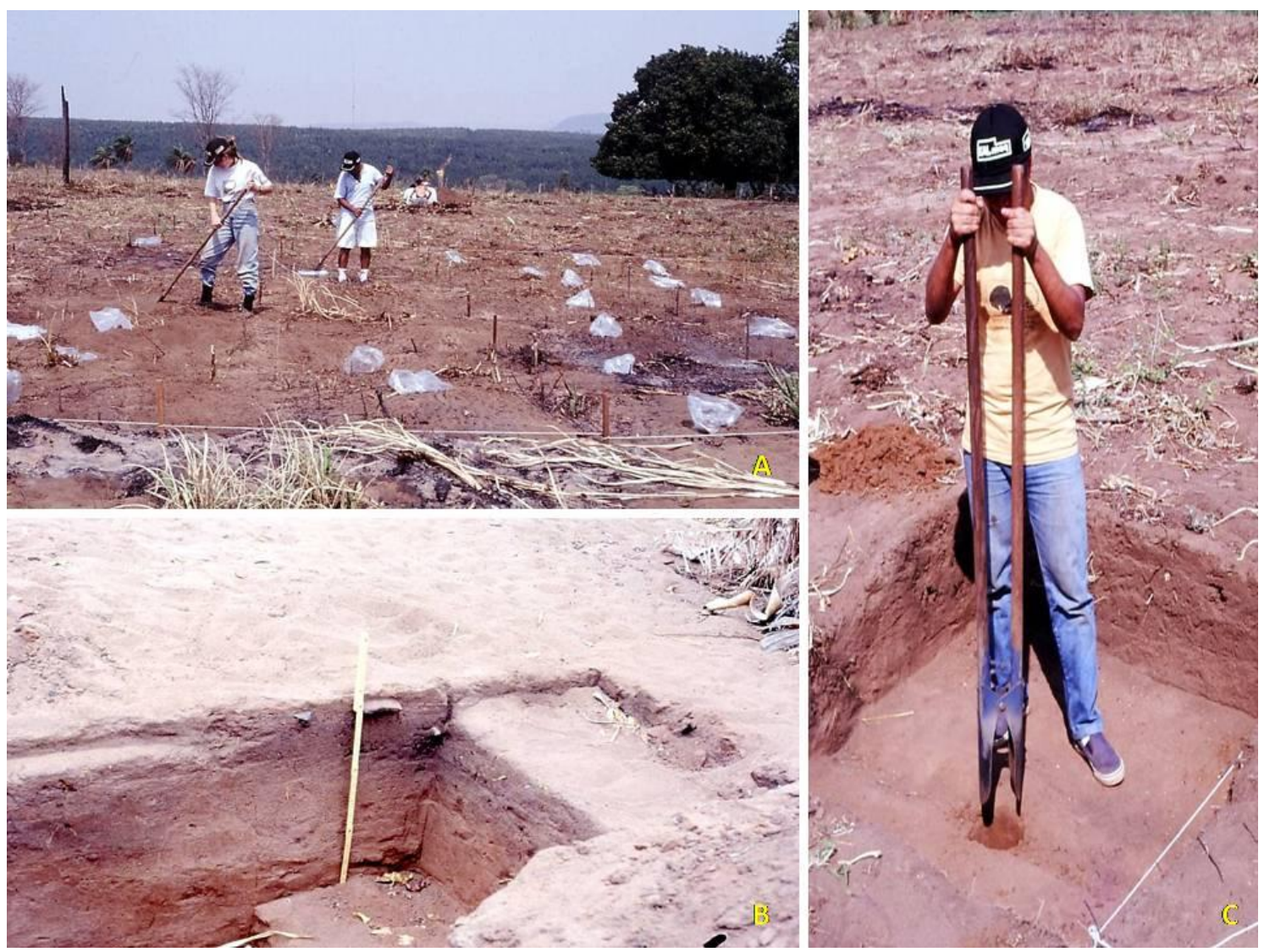

Figura 1.6 - Trabalho de escavação II. A - Daniele Klokler e Paulo Jacob; B - Perfil onde foi encontrada a urna; C - Poço-teste - Paulo Jacob. 

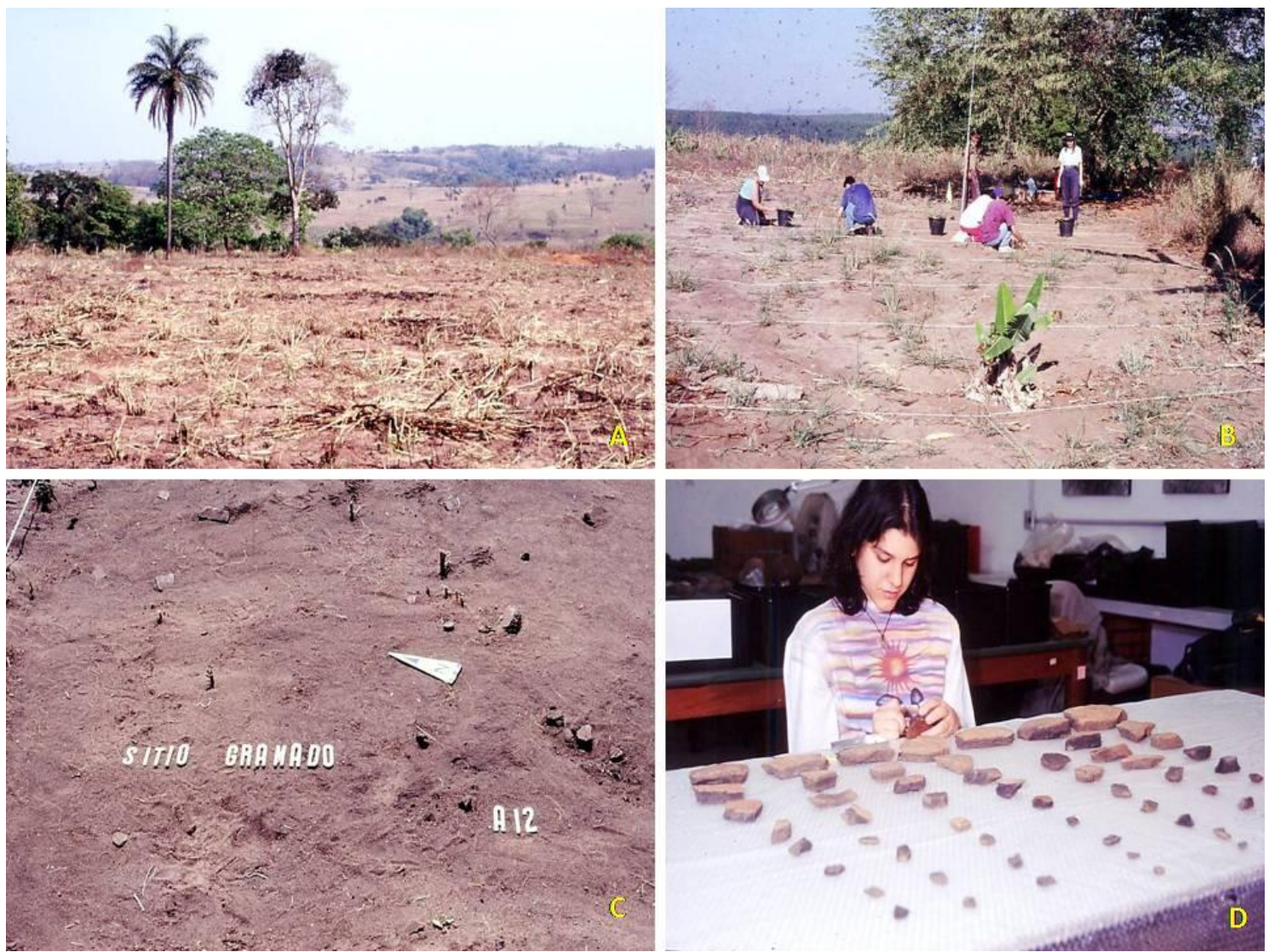

Figura 1.7 - Trabalho de escavação III e laboratório. A - Vista geral do sítio; B - Coleta de superfície; C - Mancha preta - sondagem A-12; D - Trabalho de laboratório com Mônica Goulart - bolsista de iniciação. .

\subsection{Distribuição da cerâmica no sítio Gramado}

O material coletado durante o trabalho de prospecção consiste em 5038 fragmentos cerâmicos, poucos fragmentos líticos lascados, alguns fragmentos ósseos de mamíferos, fragmentos ósseos humanos e uma urna funerária fragmentada.

Nas figuras 1.8 e 1.9 observam-se a distribuição dos fragmentos cerâmicos pelas quadras do Sítio Gramado. 
Marianne Sallum, 2011

Estudo do Gesto em Cerâmicas do Sítio Gramado

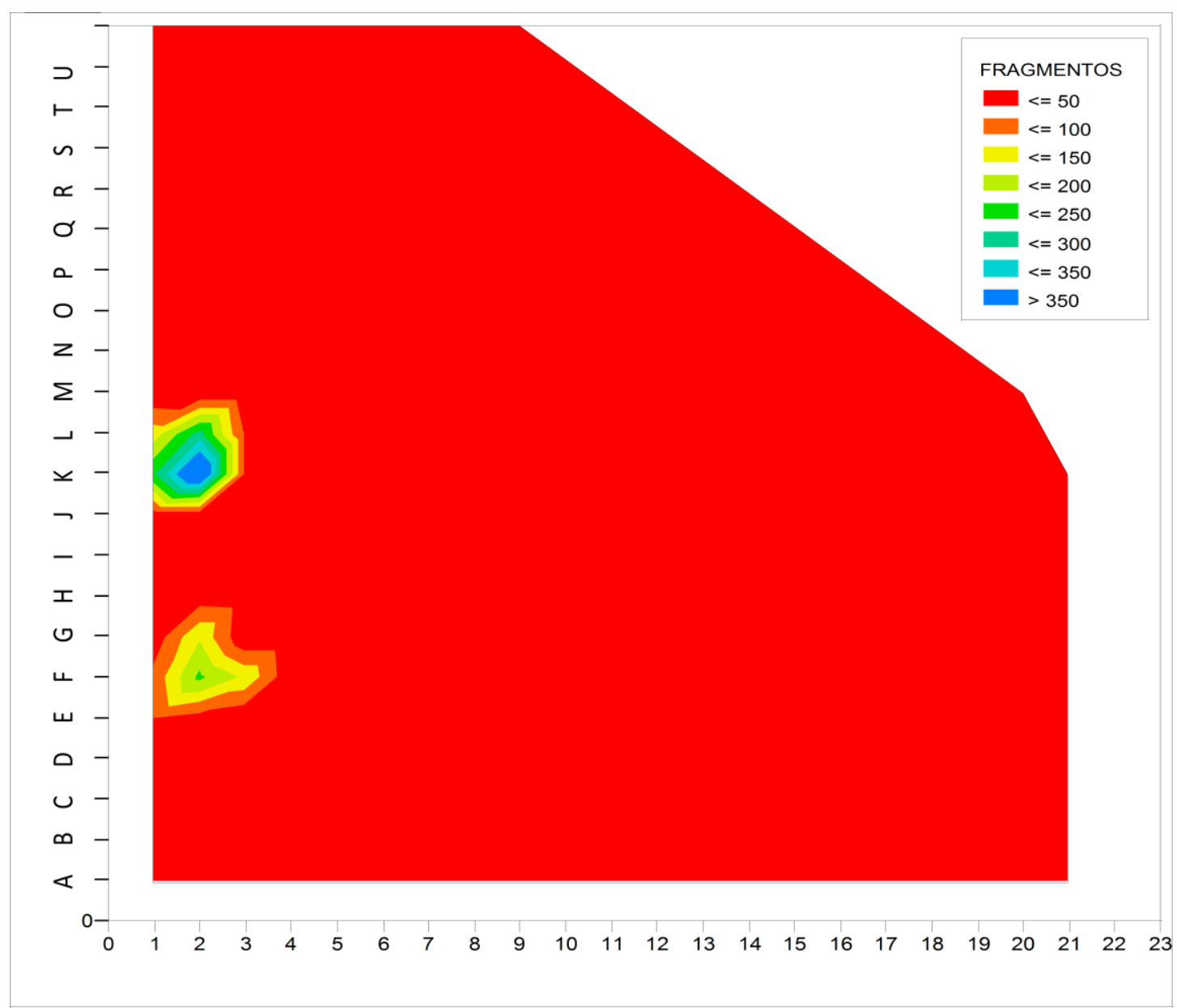

Figura 1.8 -. Diagrama de densidade de distribuição geral dos fragmentos cerâmicos, com interpolação de valores. Os valores indicam número de fragmentos e cores indicam intervalos de quantidades. 
Marianne Sallum, 2011

Estudo do Gesto em Cerâmicas do Sítio Gramado

\begin{tabular}{|c|c|c|c|c|c|c|c|c|c|c|c|c|c|c|c|c|c|c|c|c|c|c|}
\hline & $A$ & D & 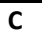 & D & 5 & $r$ & G & $\mathrm{H}$ & 1 & J & K & L & $M$ & $\mathbf{N}$ & 0 & $\mathbf{P}$ & $\mathbf{Q}$ & $R$ & $S$ & T & U. & \\
\hline 1 & $?$ & 3 & 7 & 9 & 3 & 0 & 4 & 9 & 14 & 5 & 7 & 10 & 10 & 5 & 10 & 3 & 7 & 3 & 0 & 0 & 1 & \begin{tabular}{|l|}
1 \\
\end{tabular} \\
\hline 2 & 0 & 0 & 0 & 0 & 4 & 1 & 3 & 2 & 2 & 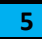 & 11 & 12 & 17 & 2 & 7 & 3 & 11 & 6 & 3 & & 5 & 2 \\
\hline 3 & 4 & 1 & 3 & 5 & 3 & - & 3 & & & & 20 & 7 & & $\epsilon$ & 5 & 3 & & 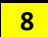 & 3 & & 2 & 3 \\
\hline 4 & 7 & 1 & 2 & 3 & 0 & 1 & 0 & & & - & & 8 & 3 & & 4 & 0 & & 3 & 3 & 0 & 3 & 4 \\
\hline 5 & 49 & 25 & 2 & 3 & 0 & 2 & C & & 5 & 3 & 11 & \begin{tabular}{|l}
10 \\
\end{tabular} & 21 & $\varepsilon$ & 0 & 0 & & & 3 & 0 & 3 & 5 \\
\hline 6 & 63 & 127 & 25 & 10 & 0 & 0 & 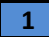 & & 1 & 2 & 0 & 4 & 4 & 4 & 0 & 0 & 3 & & 2 & 0 & 0 & 6 \\
\hline 7 & 20 & 87 & 8 & 3 & 0 & 0 & 3 & 3 & 3 & c & 4 & 0 & 0 & 2 & 11 & 0 & 0 & 0 & 1 & 0 & 1 & 7 \\
\hline 8 & 17 & 22 & 17 & 5 & 0 & 2 & 3 & 1 & 1 & 5 & 0 & 0 & 0 & 2 & 2 & 0 & c & 0 & 0 & 0 & 1 & 8 \\
\hline 9 & 8 & 20 & 16 & 10 & 3 & 0 & 4 & 1 & 3 & 1 & 8 & 0 & 0 & 2 & 0 & 0 & 0 & 0 & 1 & 2 & 6 & 9 \\
\hline 10 & 21 & 14 & 1 & 9 & 0 & 0 & 1 & 1 & 4 & 3 & 0 & 0 & $\underline{5}$ & 0 & 0 & 0 & 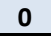 & 3 & 0 & 0 & 4 & 10 \\
\hline 11 & 81 & 209 & 3 & 8 & 2 & 2 & 3 & 4 & 4 & $\epsilon$ & 2 & 0 & 1 & 3 & 0 & 0 & 0 & 1 & 1 & 3 & 1 & 11 \\
\hline 12 & 102 & 123 & 42 & 3 & 1 & 0 & 0 & 1 & 2 & 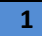 & 0 & 7 & 0 & 2 & 0 & 0 & 0 & 1 & 0 & 2 & 0 & 12 \\
\hline 13 & 4 & 1 & 1 & 6 & 1 & 0 & 3 & 2 & 0 & 1 & 1 & 0 & 0 & 2 & 2 & 3 & 0 & 2 & 0 & 1 & 0 & 13 \\
\hline 14 & 0 & 2 & 0 & 1 & 0 & 0 & 0 & 0 & 0 & c & 0 & 0 & 0 & 0 & 0 & 0 & 0 & 0 & 0 & 0 & 0 & 14 \\
\hline 15 & 6 & 0 & 14 & 0 & 0 & 0 & 0 & 0 & 0 & c & 0 & 0 & 0 & 0 & 0 & 0 & 0 & 0 & 0 & 0 & 0 & 15 \\
\hline 16 & 4 & 3 & 2 & 1 & 0 & 14 & 4 & 6 & 4 & 0 & 0 & 0 & 0 & 0 & 0 & 0 & 0 & 0 & 0 & 0 & 0 & 16 \\
\hline 17 & 1 & 1 & 2 & 1 & 0 & 14 & 1 & 3 & 1 & 0 & 0 & 0 & 0 & 0 & 0 & 0 & 0 & 0 & 0 & 0 & 0 & 17 \\
\hline 18 & 2 & 2 & 2 & 4 & 0 & 4 & 0 & 3 & $\sqrt{1}$ & 0 & 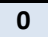 & 0 & 0 & 0 & 0 & 0 & 0 & 0 & 0 & 0 & 0 & 18 \\
\hline 19 & 0 & 0 & 2 & 4 & 1 & 5 & - & $=$ & 7 & 0 & 0 & 0 & 0 & 0 & 0 & 0 & 0 & 0 & 0 & 0 & 0 & 19 \\
\hline 20 & 1 & 3 & 6 & 9 & 10 & 6 & 0 & 3 & 1 & c & 0 & 0 & 0 & 0 & 0 & 0 & 0 & 0 & 0 & 0 & 0 & 20 \\
\hline 21 & 12 & 3 & 2 & 13 & 5 & 10 & 0 & 12 & 1 & 0 & 0 & 0 & 0 & 0 & 0 & 0 & 0 & 0 & 0 & 0 & 0 & 21 \\
\hline \multirow[t]{2}{*}{22} & 6 & 2 & 5 & 2 & 5 & 2 & 0 & 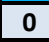 & 1 & 0 & 0 & 0 & 0 & 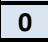 & 0 & 0 & 0 & 0 & 0 & 0 & \begin{tabular}{|l|} 
\\
\end{tabular} & 22 \\
\hline & A & B & C & D & $E$ & $F$ & G & $\mathrm{H}$ & 1 & J & $\pi$ & $\mathbf{L}$ & $M$ & N. & 0 & $\mathbf{P}$ & $\mathbf{Q}$ & $\mathbf{R}$ & S & $T$ & U & \\
\hline
\end{tabular}

A

\begin{tabular}{|r|r|r|r|r|r|r|r|r|r|r|r|r|r|r|r|r|r|r|r|r|r|r|}
\hline & A & B & C & D & E & F & G & H & I & J & K & L & M & N & O & P & Q & R & S & T & U & \\
\hline 1 & & & & & & & & & & & & & & & & & & & & & & 1 \\
\hline 2 & & & & & & & & & & & & & & & & & & & & & & 2 \\
\hline 3 & & & & & & & & & & & & & & & & & & & & & & 3 \\
\hline 4 & & & & & & & & & & & & & & & & & & & & & & 4 \\
\hline 5 & & & & & & & & & & & & & & & & & & & & & & 5 \\
\hline 6 & & 12 & 63 & & & & & & & & & & & & & & & & & & & 6 \\
\hline 7 & & 57 & & & & & & & & & & & & & & & & & & & & 7 \\
\hline 8 & & & & & & & & & & & & & & & & & & & & & & 8 \\
\hline 9 & & & & & & & & & & & & & & & & & & & & & & 9 \\
\hline 10 & & & & & & & & & & & & & & & & & & & & & & 10 \\
\hline 11 & 161 & 299 & & & & & & & & & & & & & & & & & & & & 11 \\
\hline 12 & 24 & & & & & & & & & & & & & & & & & & & & & 12 \\
\hline 13 & & & & & & & & & & & & & & & & & & & & & & 13 \\
\hline 14 & & & & & & & & & & & & & & & & & & & & & & 14 \\
\hline 15 & & & & & & & & & & & & & & & & & & & & & & 15 \\
\hline 16 & & & & & & & & & & & & & & & & & & & & & & 16 \\
\hline 17 & & & & & & & & & & & & & & & & & & & & & & 17 \\
\hline 18 & & & & & & & & & & & & & & & & & & & & & & 18 \\
\hline 19 & & & & & & & & & & & & & & & & & & & & & & 19 \\
\hline 20 & & & & & & & & & & & & & & & & & & & & & & 20 \\
\hline 21 & & & & & & & & & & & & & & & & & & & & & & 21 \\
\hline 22 & & & & & & & & & & & & & & & & & & & & & & 22 \\
\hline & A & B & C & D & E & F & G & H & I & J & K & L & M & N & O & P & Q & R & S & T & U & \\
\hline
\end{tabular}

B

\begin{tabular}{|c|c|c|c|}
\hline 0 & $2-5$ & $11-20$ & $51-100$ \\
\hline 1 & $6-10$ & $20-50$ & $>100$ \\
\hline
\end{tabular}

Figura 1.9 A e B -. Diagrama de densidade de distribuição geral dos fragmentos cerâmicos. A - Profundidade de 0 $\mathrm{cm}$ (superfície), B - Profundidade de 10 a $80 \mathrm{~cm}$. 
Na figura 1.9 A observa-se uma concentração de material cerâmico em superfície nas áreas onde posteriormente foram realizadas sondagens - próximas ao local da urna funerária quadras: 4 A, 5 A e B, 6 A-D, 7 A-C, 8 A-C, 9 A-D, 10 A-D, 11 A-D e 12 A-C. Nas outras quadras observa-se pouca presença de material de superfície, exceto por duas áreas isoladas de concentração, especificamente nas quadras: 1 H-Q, 2 K-R, 3 K-N, 4 K-L e 5 K-N; 20 C-F, 21 AF e 22 A. No entanto, a figura 1.9 B mostra que o local onde encontrou-se maior quantidade de material em superfície, também apresentou grande quantidade em profundidade.

\section{Campo - 2009}

Foi realizada uma expedição de reconhecimento, entre os dias 20 e 23 de novembro com o objetivo de determinar as coordenadas geográficas do sítio e de seu entorno com o uso do sistema de localização global (GPS) e verificar a situação atual do sítio. O sítio Gramado foi localizado e as coordenadas obtidas estão na tabela 1.2.

Tabela 1.2 - Coordenadas geográficas- (Datum: WGS 84)

\begin{tabular}{cccc} 
Local & Latitude & Longitude & Altitude (m) \\
\hline Sítio Gramado - eucalipto & $-22^{\circ} 12^{\prime} 46.3^{\prime \prime}$ & $-48^{\circ} 12^{\prime} 46.7^{\prime \prime}$ & 552 \\
Sítio Gramado - árvore abaixo & $-22^{\circ} 12^{\prime} 46,05$ & $-48^{\circ} 12^{\prime} 45.6^{\prime}$ & 550 \\
Argila 1 & $-22^{\circ} 12^{\prime} 35.9^{\prime \prime}$ & $-48^{\circ} 12^{\prime} 47.3^{\prime \prime}$ & \\
Argila 2 & $-22^{\circ} 12^{\prime} 35.8^{\prime \prime}$ & $-48^{\circ} 12^{\prime} 47.3^{\prime \prime}$ & 508 \\
Argila 3 & $-22^{\circ} 12^{\prime} 46.3^{\prime \prime}$ & $-48^{\circ} 12^{\prime} 46.7^{\prime \prime}$ & \\
Local onde se encontrou núcleo & $-22^{\circ} 15^{\prime} 56.36^{\prime \prime}$ & $-4813^{\prime} 43.09^{\prime \prime}$ & \\
com retiradas - rio Jacaré Pepira & & & \\
\hline
\end{tabular}

O início da visita consistiu em encontrar o local exato da fazenda seguindo indicações da equipe que participou do trabalho em 1994. Chegando à zona rural de Brotas, os moradores de outras fazendas indicaram como chegar à fazenda, pois conheciam a história de "um índio encontrado dentro de um vaso" anos atrás.

O Sr. Mário Gastaldi (proprietário da fazenda) havia falecido e a esposa e filhos cuidavam da fazenda naquele momento. Realizou-se uma entrevista com a Dona Marina Gastalti (viúva do 
proprietário) (figura 1.7). Da entrevista, destaca-se o relato de como encontraram a urna funerária e o que fizeram com ela depois. Segundo relator, durante o trabalho de arado do solo, o maquinário agrícola trouxe à superfície parte da urna. A família retirou o objeto já com rachaduras e levou para dentro de casa como decoração. Alguns dentes foram levados por amigos e vizinhos que utilizaram como colares (adornos). Porém, sob o pretexto de trazer mau agouro, a família Gastaldi decidiu enterrar novamente o objeto, levando em conta o lugar onde foi encontrado inicialmente.

Verificou-se que a zona onde ocorreu em 1994 o trabalho de escavação e sondagem encontrava-se uma plantação de cana de açúcar e muita cerâmica na superfície. Como a cana era jovem, o solo estava exposto e foi possível observar à distância a exposição de muitos fragmentos e reconhecer a cerâmica, como tipos de borda, espessura, pintura, engobo e decoração plástica. A cerâmica encontrada na superfície era bem parecida com a cerâmica analisada em laboratório, como resultado da primeira coleta.

Dentro da fazenda encontrou-se uma área que poderia ter sido utilizada como fonte de argila (Figura 1.8 A). O local consiste em uma grota com talude de cerca de $4 \mathrm{~m}$ de altura, com vertente orientada de SE para NO, com afloramento de camadas inferiores de solo e mina d água. De jusante nasce um regato, que alaga parcialmente um baixio, onde se localiza argila úmida na base dos taludes. A argila encontrada é de coloração escura, muito plástica e sem grãos de areia. Foram coletadas três amostras de barro, porém não foi realizada análise para entender se havia relação com a cerâmica do sítio arqueológico (figura 1.8 B).

Para compreender a área indireta do sítio Gramado, realizou-se um percurso de barco pelo rio Jacaré Pepira, com o intuito inicial de coletar alguns seixos a serem utilizados no alisamento e acabamento da argila durante a atividade de experimentação. Percebeu-se que a distância entre o Rio Jacaré Pepira e a Fazenda Aparecida do Gramado era de apenas cinco quilômetros, além disso, na base da colina perto da fazenda encontra-se um afluente do rio Jacaré-Pepira. Pode-se, com isso, deduzir que talvez existisse uma relação entre os dois lugares. Durante o percurso de barco aconteceu uma parada em uma pequena ilha do rio onde se encontrou um núcleo lítico com marcas de percussão (figura $1.8 \mathrm{C}$ ).

Nas figuras 1.10 e 1.11 observam-se imagens do sítio Gramado em visita realizada em 2009. 
Marianne Sallum, 2011

Estudo do Gesto em Cerâmicas do Sítio Gramado
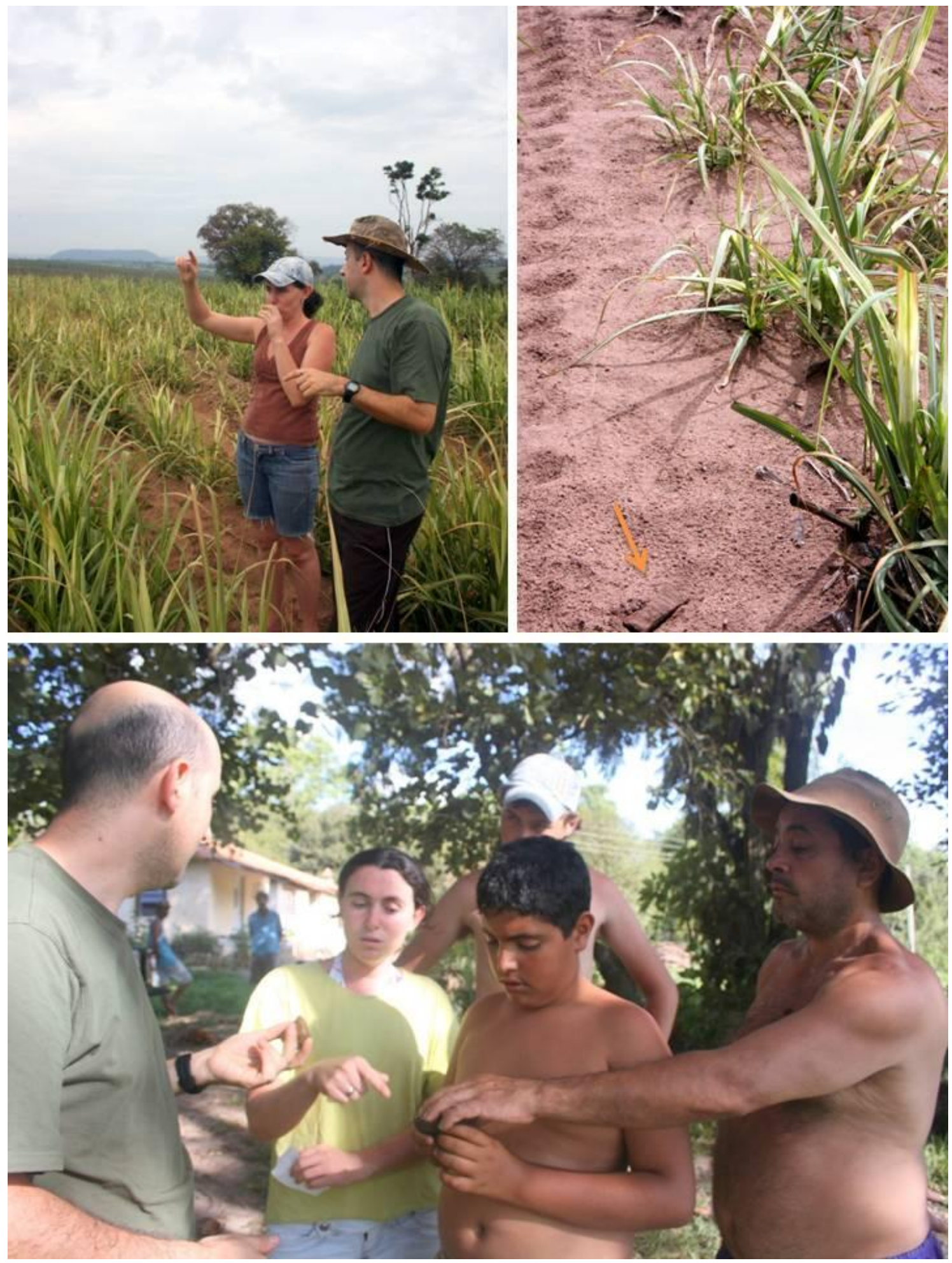

Figura 1.10 - sítio Gramado em visita de 2009 (1) A - Filha de Dona Marina Gastaldi mostrando a área do sítio; B - Cerâmica na superfície. C - Moradores da fazenda. 
Marianne Sallum, 2011

Estudo do Gesto em Cerâmicas do Sítio Gramado
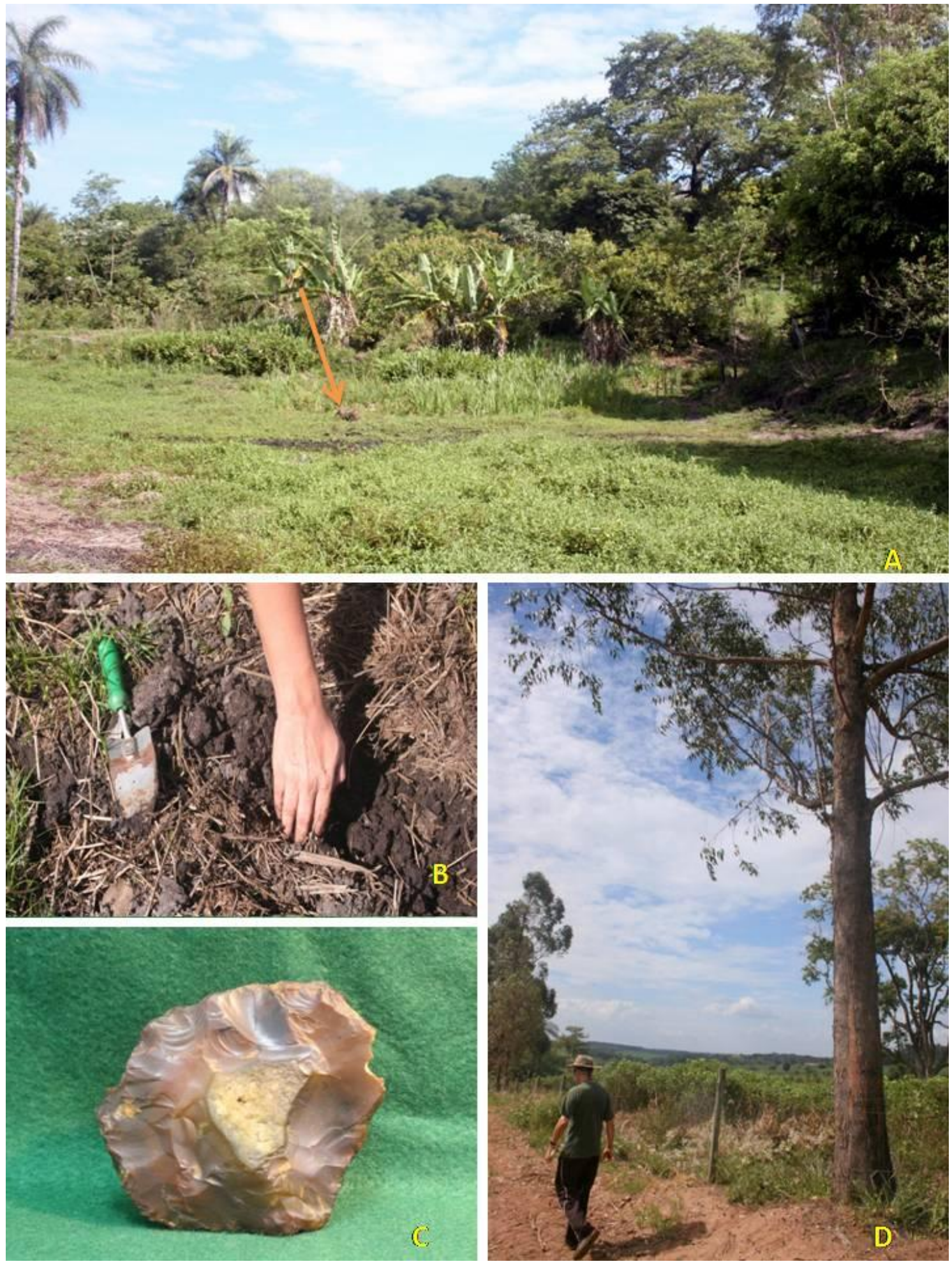

Figura 1.11 - sítio Gramado em visita de 2009 (2) - A - Local da possível fonte de barro; B - Barro; C Lítico encontrado no rio Jacaré Pepira; D - sítio Gamado.

\subsection{Conclusão:}

A partir da apresentação dos diagramas de distribuição de material cerâmico no sítio Gramado, observou-se que apesar de período curto de prospecção e coleta de material (15 dias), 
encontrou-se grande quantidade de cerâmica arqueológica em superfície e em profundidade de até $80 \mathrm{~cm}$, além de mostrar a presença de duas outras áreas de concentração de material (figura 1.9 A). Ficou claro que o sítio Gramado tem um grande potencial para novas escavações e evidencia a importância de realizar pesquisas sistemáticas na região, fato confirmado pela visita realizada em 2009, no qual se constatou, depois de 15 anos da primeira etapa de campo, a presença de muito material arqueológico em superfície. 


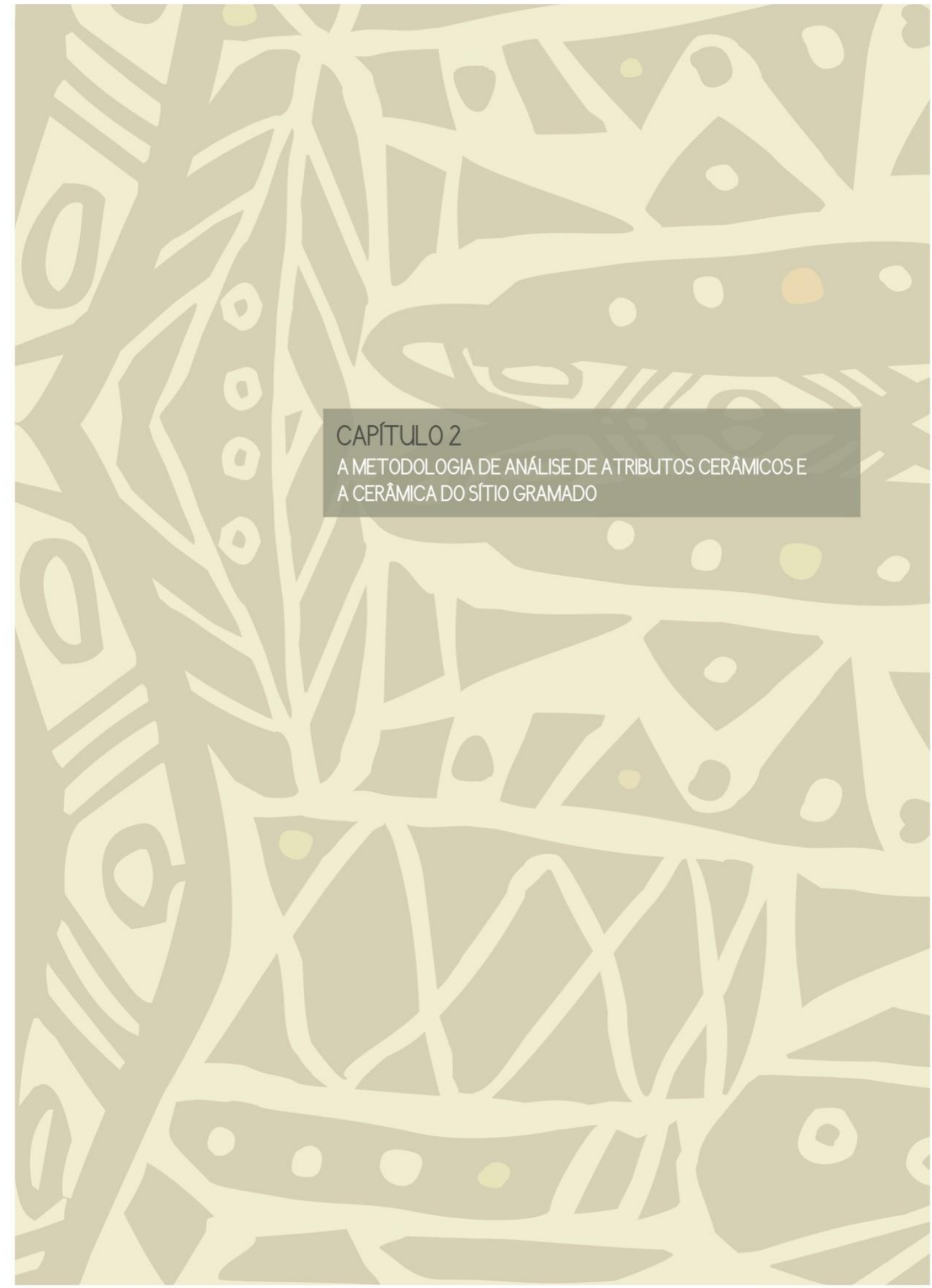




\section{SUMÁRIO}

Capítulo 2 - A metodologia de análise de atributos cerâmicos e a cerâmica do sítio

\section{Gramado}

2.1 Introdução

2.2 O sítio Gramado

2.3 Material e Métodos

2.4 Resultados e discussão

2.5 Conclusão

\section{Figuras}

2.1 Mapa do Estado de São Paulo e localização do sítio Gramado

2.2 Estudos de decoração plástica

2.3 Estudos de pintura

2.4 Classificação de queima

2.5 Tipos de base

2.6 Proporção entre classe e espessura

2.7 Decoração plástica I

2.8 Decoração plástica II

2.9 Decoração plástica III

2.10 Decoração plástica IV

2.11 Proporções entre decoração plástica e espessura

2.12 Cerâmica do sítio Gramado I

2.13 Cerâmica com decoração pintada

2.14 Bordas com pintura

2.15 Padrões estilísticos da cerâmica do sítio Gramado

2.16 Proporção entre decoração pintada e espessura 


\section{Tabelas}

2.1 Atributos cerâmicos

2.2 Decoração plástica

2.3 Padrões de pintura

2.4 Números de peças por tipo: parede, borda e base

2.5 Distribuição entre classe e espessura

2.6 Distribuição de decoração plástica

2.7 Distribuição entre decoração plástica e espessura

2.8 Distribuição de decoração pintada

2.9 Distribuição entre decoração pintada e espessura 


\begin{abstract}
"Desde cedo os indivíduos se habituam a ver e a desenhar padrões convencionais, a produzir artefatos peculiares a cada tribo, familiarizando-se com essas imagens que passam a ser a forma de exprimirem seu modo de ser, sua personalidade cultural. (Ribeiro, B. G.: 1989, Arte Indígena - Linguagem Visual)
\end{abstract}

\title{
2.1 Introdução
}

No decorrer da história, a confecção da cerâmica atendeu a uma necessidade basicamente utilitária, seja no preparo de alimentos ou mesmo em seu armazenamento, posteriormente foramlhe imbuídas funções ritualísticas e decorativas. Ao observar como cada sociedade constrói seus objetos, percebe-se que cada uma tem sua "personalidade cultural", visível nos elementos construtivos e decorativos de um pote, ou seja, quando se identifica uma técnica, encontra-se indissociável estilo étnico. (Balfet, 1991).

Assim, por meio da construção manual de uma peça cerâmica, encontram-se idéias e formas de organizações sociais, nos quais o entendimento requer um profundo conhecimento da cosmologia e de outros aspectos da cultura (Ribeiro, 1989).

As características de uma sociedade são percebidas através de costumes e condutas marcadas no indivíduo desde a sua infância. Segundo Mauss (1974) "Adestram-se as crianças... a dominar reflexos... inibem-se medos... selecionam-se pausas e movimentos." Para o autor, nenhum movimento é fútil ou supérfluo, pois são nas sutilezas dos gestos que se encontram comportamentos sociais profundos.

Para Boas (1955), o processo de criação de um objeto exige o domínio de sua matéria prima e principalmente a aceitação dele pelo grupo.

No Brasil, os estudos tecnológicos da cerâmica, tiveram inicio na década de 60 do século XX, com os arqueólogos do Programa Nacional de Pesquisas Arqueológicas (PRONAPA) e com os trabalhos de com o trabalho de Meggers e Evans (1970), que influenciados pela corrente norte-americana, formularam o conceito de "tradição" para os achados arqueológicos daquele momento.

Com relação às tradições, destaca-se a classificação realizada por Robrahn-González (1996) para o estado de São Paulo: tradição Tupiguarani com vestígios por todo o Estado; tradição Itararé na porção sul e tradição Aratu-Sapucaí no norte, centro-oeste e nordeste. Bem 
como, os trabalhos de mestrado e doutorado de Scatamacchia (1981, 1984), no qual a autora apresenta sínteses, tanto dos dados arqueológicos e etno-históricos, como bibliográficos para as classificações terminológicas de material cerâmico.

Com as pesquisas desenvolvidas pelo PRONAPA, definiram-se características comuns observadas nas cerâmicas consideradas de tradição Tupiguarani, como: cerâmicas pintadas com traços vermelhos ou pretos sobre fundo branco, bem como decorações unguladas e corrugadas (Prous, 2007).

Brochado (1981) formulou tese sobre a existência de um padrão cultural entre os Guarani e Tupinambá, criando uma metodologia de análise cerâmica baseada em aspectos morfológicos (Noelli, 2008). Para ele, a cerâmica Tupiguarani possuía um "Estilo Geométrico Gráfico" caracterizado, principalmente, pela singularidade de sua pintura: decoração policromatica e cores fortes. Em algumas peças encontrava-se somente engobo vermelho nas paredes como forma de acabamento (figura 2.12).

Quanto à confecção da cerâmica Tupiguarani e suas possíveis utilizações, Prous (2006) afirmou que essa cerâmica esteve desde o período pré-histórico associada à atividade basicamente feminina. Apesar de existirem poucas análises sobre a utilização das cerâmicas em unidades habitacionais, sabe-se que cada família possuía poucos recipientes, entre eles, grandes vasilhas de quase 1m de diâmetro que eram utilizadas para guardar água ou cauim (bebida feita por mulheres com mandioca ou milho mastigado). Esses recipientes, muitas vezes, eram reutilizados posteriormente em sepultamento de adultos. Entre os Guarani, as vasilhas grandes recebiam o nome de cambuchi e, entre os Tupi, igaçaba. Recipientes médios para cozinhar e pequenos (20 a $30 \mathrm{~cm}$ de diâmetro) para servir a comida e bebida também eram encontrados.

\subsection{Sítio Gramado}

O sítio encontra-se na Fazenda Aparecida do Gramado, município de Brotas, Região central do Estado de São Paulo (Figura 2.1). Em 1994, após trabalho de prospecção na fazenda, foram coletados cerca de 5.000 fragmentos cerâmicos, que atualmente estão acondicionados na reserva técnica do Museu de Arqueologia e Etnologia da Universidade de São Paulo. O sítio Gramado, devido às características estilísticas de sua cerâmica, associa-se a tradição Tupiguarani. 


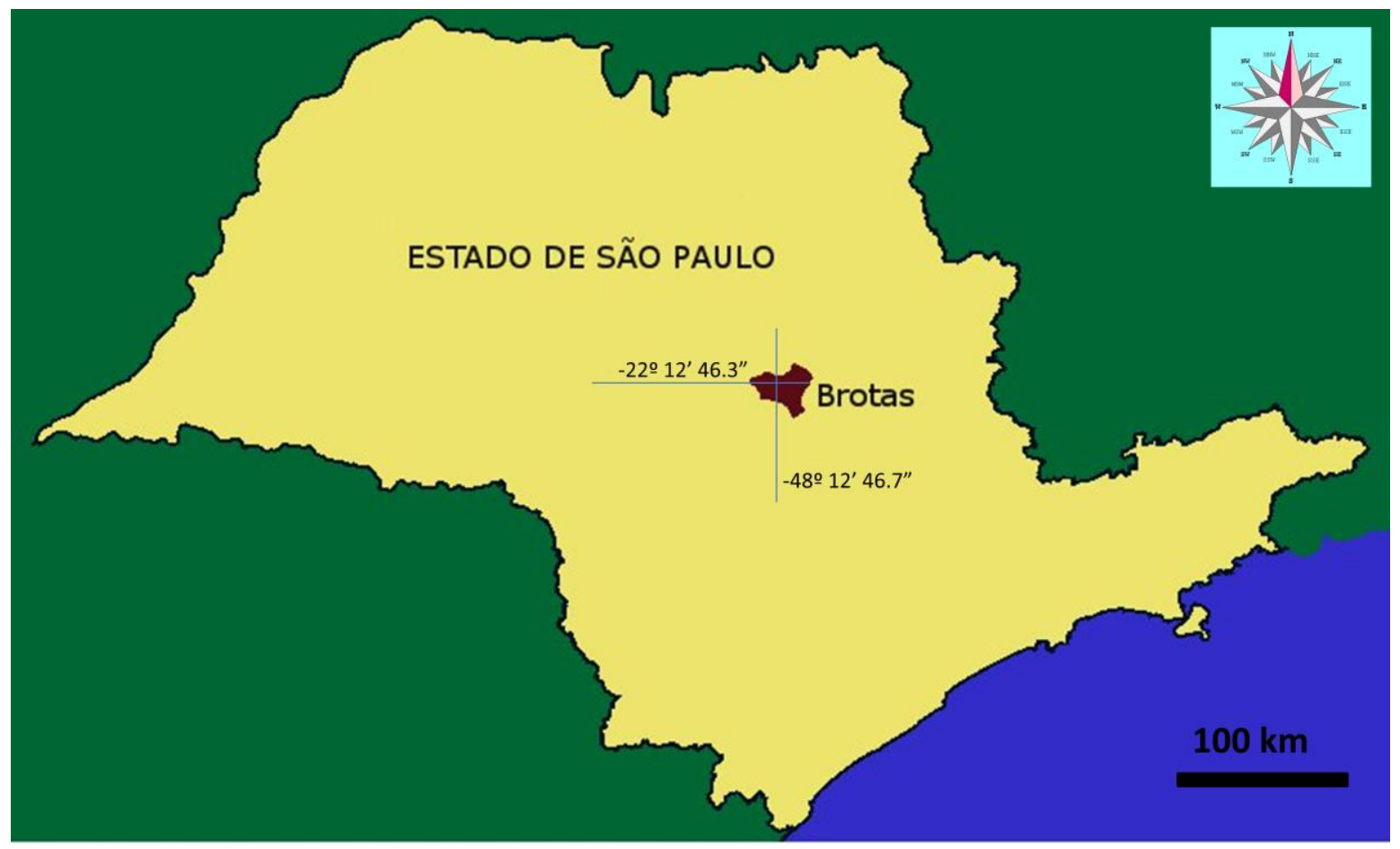

Figura 2.1 - Mapa do Estado de São Paulo e localização do sítio Gramado no município de Brotas

No Estado de São Paulo destacam-se trabalhos importantes para compreender a ocupação humana na região. São alguns deles: as pesquisas em Monte-Mor e Campinas (Aytai 1991); no nordeste do Estado (Caldarelli 1983, Morais 2007); no Vale do Paranapanema (Pallestrini 197981; Morais 1999; Araújo 2001); no Alto Taquari (Araújo 1995).

Apesar das várias pesquisas realizadas, ainda existe uma lacuna de estudos de sítios arqueológicos na região central do Estado. Considerando esse aspecto e a disponibilidade de grande volume e aparente diversidade de material cerâmico do sítio Gramado, o objetivo desse capítulo é apresentar e discutir o método de análise de atributos, bem como identificar quais os tipos mais freqüentes de decoração e sua relação com tratamento de superfície e espessura.

\subsection{Material e Métodos}

O material examinado consiste em 4.332 fragmentos cerâmicos do sítio Gramado, região do Vale médio do Rio Tietê, São Paulo.

Para análise das características cerâmicas utilizou-se uma planilha de atributos cerâmicos criada por Moraes (2007) adequando-a conforme as peculiaridades da cerâmica do sítio Gramado. A planilha enfatizou os tipos de decoração plástica. Além disso, analisaram-se as decorações pintadas, espessura de fragmento, queima e tratamento de superfície (tabela 2.1). 
Tabela 2.1 - Atributos cerâmicos selecionados, suas categorias ou estados de caráter.

\begin{tabular}{|c|c|c|c|c|}
\hline Unidade & Níve & Classe & $\begin{array}{l}\text { Espessura } \\
\text { em mm }\end{array}$ & $\begin{array}{l}\text { Tipo de decoração } \\
\text { Plástica }\end{array}$ \\
\hline $\begin{array}{l}\text { S1.sondagem1 } \\
\text { S123.sondagem1,2,3 } \\
\text { S3.sondagem3 } \\
\text { S4.sondagem4 } \\
\text { S5.sondagem5 } \\
\text { S6.sondagem6 } \\
\text { S7.sondagem7 } \\
\text { Q.sondagem Q } \\
\text { CSB.coleta seletiva de } \\
\text { bordas } \\
\text { CSBP. Coleta seletiva de } \\
\text { bordas pintadas }\end{array}$ & $\begin{array}{l}\text { CS - Coleta seletiva } \\
\text { D1 - 0 a } 10 \mathrm{~cm} \\
\text { D2 - } 10 \text { a } 20 \mathrm{~cm} \\
\text { D3 - } 20 \text { a } 30 \mathrm{~cm} \\
\text { D4 - } 30 \text { a } 40 \mathrm{~cm} \\
\text { D5 - } 40 \text { a } 50 \mathrm{~cm} \\
\text { D6 - } 50 \text { a } 60 \mathrm{~cm} \\
\text { D7 - 60 a } 70 \mathrm{~cm} \\
\text { D8 - } 70 \text { a } 80 \mathrm{~cm} \\
\text { MP - material peneirado } \\
\text { CAN - área de canavial } \\
\text { S/E - sem etiqueta }\end{array}$ & $\begin{array}{l}\mathrm{P} \text { - parede } \\
\mathrm{B} \text { - borda } \\
\mathrm{BS} \text { - base } \\
\mathrm{BC} \text { - borda carenada } \\
\mathrm{O} \text { - ombro } \\
\mathrm{BO} \text { - bolota } \\
\mathrm{BP} \text { - borda e parede } \\
\mathrm{SL} \text { - sem leitura }\end{array}$ & $\begin{array}{l}\text { A }-4 \text { a } 8.99 \\
\text { B }-9 \text { a } 14.99 \\
\text { C }-15 \text { a } 20.99 \\
D-21 \text { a } 26.99 \\
\text { E - 27 a } 32\end{array}$ & $\begin{array}{l}\text { I, II, III, IV, V, VI, VII, } \\
\text { VIII, IX, X, XI, XII, } \\
\text { XIII, XIV, XV, XVI, } \\
\text { XVII e XVIII. } \\
\text { Classificação: de La } \\
\text { Salvia } \\
\text { \& Brochado (1989). } \\
\text { Tabela } 2.2\end{array}$ \\
\hline Decoração pintada & Queima & Tipo de base & Técnica & Trat. de superfície \\
\hline $\begin{array}{l}0 \text { - ausência } \\
1 \text { - presença }\end{array}$ & $\begin{array}{l}1,2,3,4,5,6,7, \text { e } 8 . \\
\text { Classificação de Rye (1981). } \\
\text { Figura } 2.4\end{array}$ & $\begin{array}{l}\text { CV - convexa } \\
\text { CO - côncava } \\
\text { PL - plana } \\
\text { PE - pedestal } \\
\text { Classificação de Chmyz } \\
\text { (1976). Figura } 2.5\end{array}$ & $\begin{array}{l}\mathbf{A} \text { - acordelado } \\
\mathbf{M} \text { - modelado } \\
\mathbf{A M} \text { - acordelada } \\
\text { e modelada } \\
\mathbf{T} \text { - torneada } \\
\text { Classificação: La } \\
\text { Salvia \& Brochado } \\
\text { (1989). }\end{array}$ & $\begin{array}{l}\text { AB - alisado bom } \\
\text { ARE - alisado regular } \\
\text { ARU - alisado ruim } \\
\text { BA - barbotina } \\
\text { BR - brunidura }\end{array}$ \\
\hline
\end{tabular}

Decoração plástica:

Para entender a decoração plástica utilizou-se a classificação modificada de La Salvia \& Brochado (1989) (tabela 2.2), bem como desenhos com grafite de tipos decorativos. 
Tabela 2.2 - Decoração plástica modificada de La Salvia e Brochado (1989).

\begin{tabular}{|c|c|}
\hline Tipo de decoração & Descrição \\
\hline I - Corrugado Clássico & Dobras produzidas pela lateral do dedo para junção dos roletes. \\
\hline II - Corrugado perpendicular & Dobras escalonadas no sentido longitudinal. \\
\hline III - Corrugado oblíquo & Dobras cuja terminação forma uma linha contínua e oblíqua a borda. \\
\hline IV - Corrugado assimétrico & Junção dos roletes não possui simetria \\
\hline V - Corrugado ungulado & Corrugado com a presença da decoração ungulada. \\
\hline VI - Corrugado grosseiro & As dobras são feitas desordenadamente, sem ritmo e sobrepostas. \\
\hline VII - Digito-ungulado clássico & Polpa do dedo armado com a unha perpendicularmente a superfície da parede. \\
\hline VIII - Ungulado clássico & Pressão na superfície de objeto que forma ungulações (unha, madeira e etc). \\
\hline IX - Ungulado oblíquo & $\begin{array}{l}\text { Ungulações dispostas de forma alternada formando, na seqüência, uma linha oblíqua em } \\
\text { relação à borda da vasilha. }\end{array}$ \\
\hline $\mathrm{X}$ - Ungulado secante & $\begin{array}{l}\text { Quando as ungulações dispostas transversalmente à borda da vasilha se cruzam em seu ponto } \\
\text { terminal. }\end{array}$ \\
\hline $\mathrm{XI}$ - Ungulado arrastado & $\begin{array}{l}\text { O artesão ao produzir a ungulação arrasta uma parte da argila aumentando a expressão } \\
\text { decorativa e aumentando a argila no sentido contrário }\end{array}$ \\
\hline XII - Ungulado tangente & Quando as ungulações dispostas perpendicularmente tocam-se em seus pontos terminais. \\
\hline XIII - Roletado plano & $\begin{array}{l}\text { Quando os roletes, após sua aplicação, são aplanados na superfície dando a impressão de um } \\
\text { acordelamento por placas e não roletes. }\end{array}$ \\
\hline $\begin{array}{l}\text { XIV - Ungulado em linha } \\
\text { simétrica perpendicular }\end{array}$ & $\begin{array}{l}\text { Ungulações perpendiculares, interligadas em linhas simétricas, também perpendiculares, } \\
\text { formando conjuntos intercalados com espaços lisos. }\end{array}$ \\
\hline XV - Ungulado assimétrico & Ungulações perpendiculares sem simetria. \\
\hline XVI - Corrugado simples & $\begin{array}{l}\text { A junção dos roletes fica marcada por ondas simétricas no sentido longitudinal e } \\
\text { individualizada no perfil transversal. }\end{array}$ \\
\hline XVII - Nodulado aplicado & Aplicação de nódulos de argila preparados e colados à superfície da vasilha. \\
\hline XVIII - Ponteado clássico & Utilização de instrumento que deixa como marca um ponto. \\
\hline XIV - Corrugado-espatulado & Corrugado utilizando instrumento com forma de espátula. \\
\hline
\end{tabular}

De forma a documentar as formas e padrões realizaram-se uma série de desenhos de estudo com lápis das decorações plásticas do sítio Gramado que serviram para identificar detalhes da confecção das peças (figura 2.2).

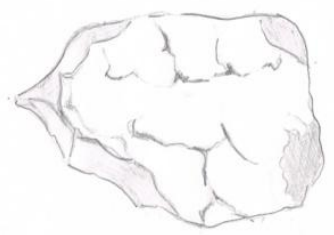

A

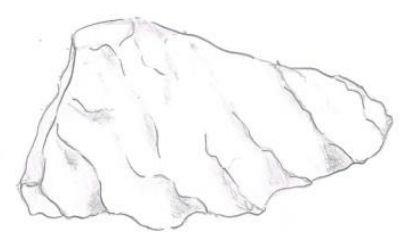

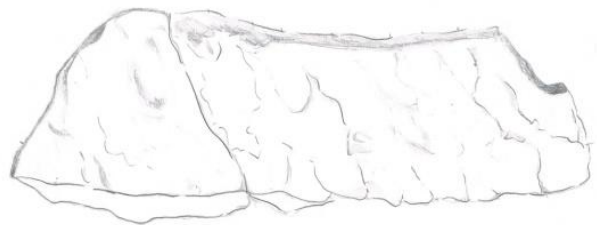

B

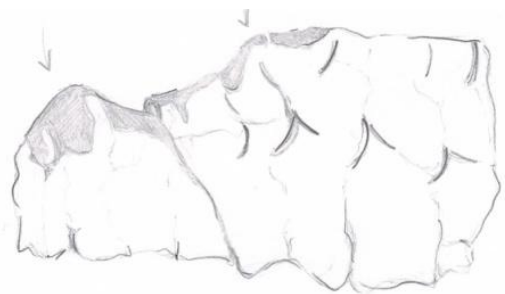

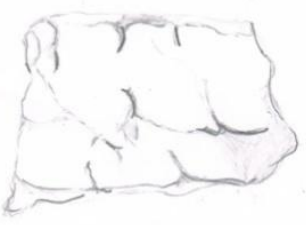

$\mathrm{C}$

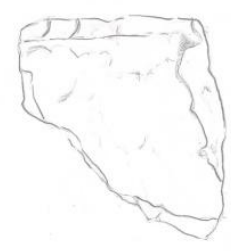

F

$\mathrm{D}$

$\mathrm{E}$

Figura 2.2 - Estudos de decoração plástica. A- corrugado clássico; B - corrugado perpendicular; C - corrugadoungulado; D - corrugado oblíquo, E - corrugado-ungulado e F corrugado na parede e ungulado na borda. 


\section{Decoração pintada}

A pintura consiste na técnica de aplicar pigmentos minerais ou vegetais no corpo da peça cerâmica, podendo ser na forma de engobo (antes da queima) ou não. Engobo é uma camada de argila com pigmentação diferente da pasta base (adição de carvão, minerais coloridos como: filito, caulinita e mica) aplicada à superfície da parede da peça antes de queimada.

Com relação à cerâmica do sítio Gramado, foram encontrados poucos fragmentos com tamanho suficiente que puderam ser classificados por tipos de pintura, por isso optou-se por definir (0) ausência e (1) presença. Para os fragmentos em que a pintura estava mais bem conservada realizaram-se desenhos e relevés para entender alguns padrões decorativos de pintura, como definido pela tabela 2.3 .

Tabela 2.3 - Padrões de pintura. Modificada de La Salvia \& Brochado (1989).

\begin{tabular}{llll} 
Local da pintura & Tipos de linha & Orientação da linha & \multicolumn{1}{c}{ Espessura da faixa } \\
\hline Lábio & Retas & Transversal & Fina 5 a $9,9 \mathrm{~mm}$ \\
Borda & Curvas & Longitudinal & Estreita 10 a $29,9 \mathrm{~mm}$ \\
Inflexões & Tracejados & Oblíqua & Média 30 a $49,9 \mathrm{~mm}$ \\
Parede & Retas e curvas & Sinuosa & Larga $>50 \mathrm{~mm}$ \\
\hline
\end{tabular}

Na figura 2.3 são apresentadas imagens dos estudos de desenho. Para realização da cópia foram utilizados, fotografia do fragmento, papel transparente (vegetal), grafite $0.7 \mathrm{~mm}$, tinta aquarela e giz pastel oleoso.

\section{Queima}

Para interpretação da qualidade da queima utilizou-se a classificação de Rye (1981), conforme figura 2.4, modificada de Moraes (2007). 

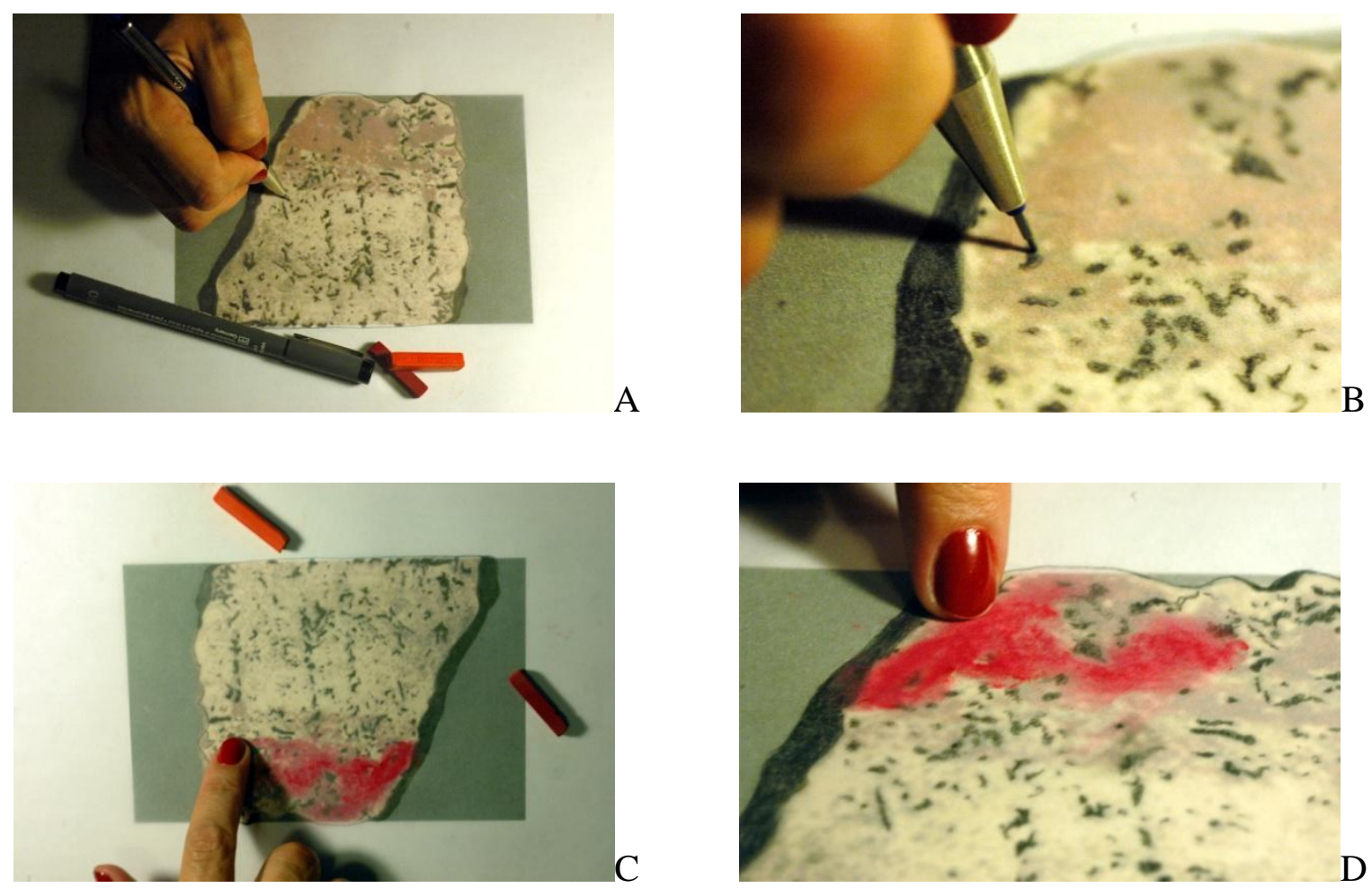

Figura 2.3 - Estudos de pintura. A e B - Contorno com grafite das áreas com linha preta; C e D - Pintura das faixas vermelhas com giz pastel.
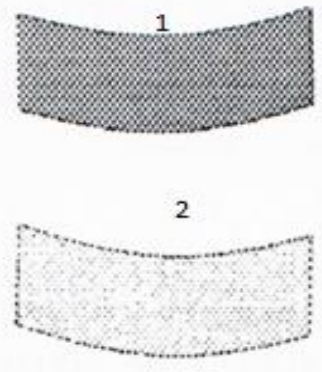

3

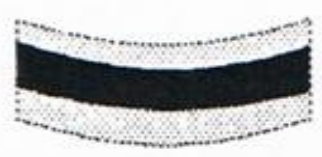

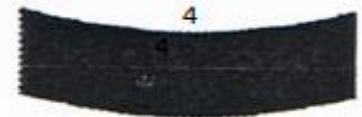

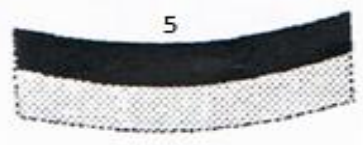

6

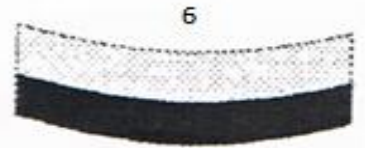

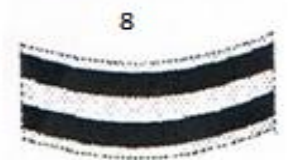

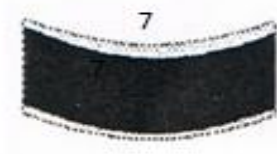

8

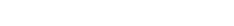

Figura 2.4 - Classificação de queima. 1 - Sem núcleo definido com cor do laranja tijolo ao amarelo, 2 Sem núcleo definido com cor uniforme do cinza claro ao pardo, 3 - Presença de núcleo escuro e camadas claras nas extremidades, 4 - Sem núcleo com cor do cinza ao preto, 5 - Camada clara na parte externa e escura na parte interna, 6 - Camada escura na parte externa e clara na parte interna, 7 - Núcleo central espesso e camadas oxidadas finas e 8 - Seções reduzidas e oxidadas de modo alternado. Rye (1981), desenho modificado de Moraes (2007). 
Tipo de base

Para interpretação do tipo de base, foi utilizada a classificação de Chmyz (1976) (figura 2.5).

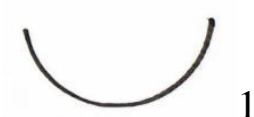

1. Convexa

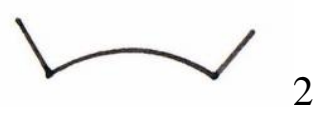

2. Côncava

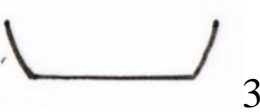

3. Plana

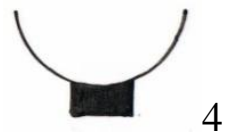

4. Pedestal

Figura 2.5 - Tipos de Base. Desenho original baseado na tipologia de Chmyz (1976).

\section{Técnica}

As técnicas de construção da peça foram classificadas em: acordelada-superposição de roletes de argila; modelada -construção de formas a partir de uma massa de argila; moldada utilização de um molde para construção de uma peça e torneada - uso de aparato composto por uma base redonda, muitas vezes de madeira ou rocha, no qual o ceramista gira a peça para sua confecção. (La Salvia \& Brochado, 1989).

\section{Engobo}

Caracteriza-se pela argila decantada que se aplica na superfície da cerâmica crua. Para os ceramistas atuais, toda a pintura realizada antes da queima é definida como engobo. A escolha do barro para o engobo é de grande importância, uma vez que a plasticidade deve ser idêntico ao da pasta cerâmica, caso contrário se desprenderá ou se escamará ao secar-se (Mattison, 2004).

Essa posição é diferente de alguns dos trabalhos arqueológicos, para quem o engobo e a pintura são elementos decorativos diferentes, mesmo que os dois tenham sido realizados antes da queima.

Por isso, faz-se necessário uma clara distinção e esclarecimento de qual posição foi adotada neste trabalho. Assim foram considerados como engobo toda a pintura realizada antes da queima (Mattison, 2004).

\subsection{Resultados e Discussão}

A partir da análise de atributos cerâmicos e de estudos de desenho e pintura foi possível inferir sobre aspectos da cerâmica decorada do sítio Gramado.

Com relação à quantidade de fragmentos de cada classe, analisou-se um total de 4.332 peças de cerâmica, porém como parte da prospecção consistiu em coleta seletiva de bordas, não 
foi possível estabelecer uma análise matemática entre freqüência de tipos (borda ou não) e número de fragmentos, de forma a estimar o número total de vasilhames originais.

Na tabela 2.4 são apresentadas as proporções de peças entre paredes (P), bordas (B) e bases (BS). Observa-se que apesar da coleta seletiva de bordas e cerâmicas decoradas, as maiorias dos fragmentos são constituídas de parede. Ressalta-se, também, a existência de apenas seis fragmentos de base, enquanto bordas constituem $9,4 \%$.

Tabela 2.4 - Número de peças por tipo: parede, borda e base

\begin{tabular}{ccc} 
Parte do fragmento & Quantidade & \% \\
\hline B - borda & 409 & 9,4 \\
BS - Base & 6 & 0,01 \\
P - Parede & 3917 & 90,4 \\
Total & 4332 & 100 \\
\hline
\end{tabular}

$\mathrm{Na}$ figura 2.6 temos a proporção de classe (borda, parede e base) e suas respectivas espessuras. Verifica-se que o maior número de ocorrências, tanto de parede, como de base, encontram-se com espessura entre 9 a $14.99 \mathrm{~mm}$. Vale ressaltar que os fragmentos de parede possuem espessuras significativas também entre 4 a 8.99 mm e 15 a 20.99 mm.

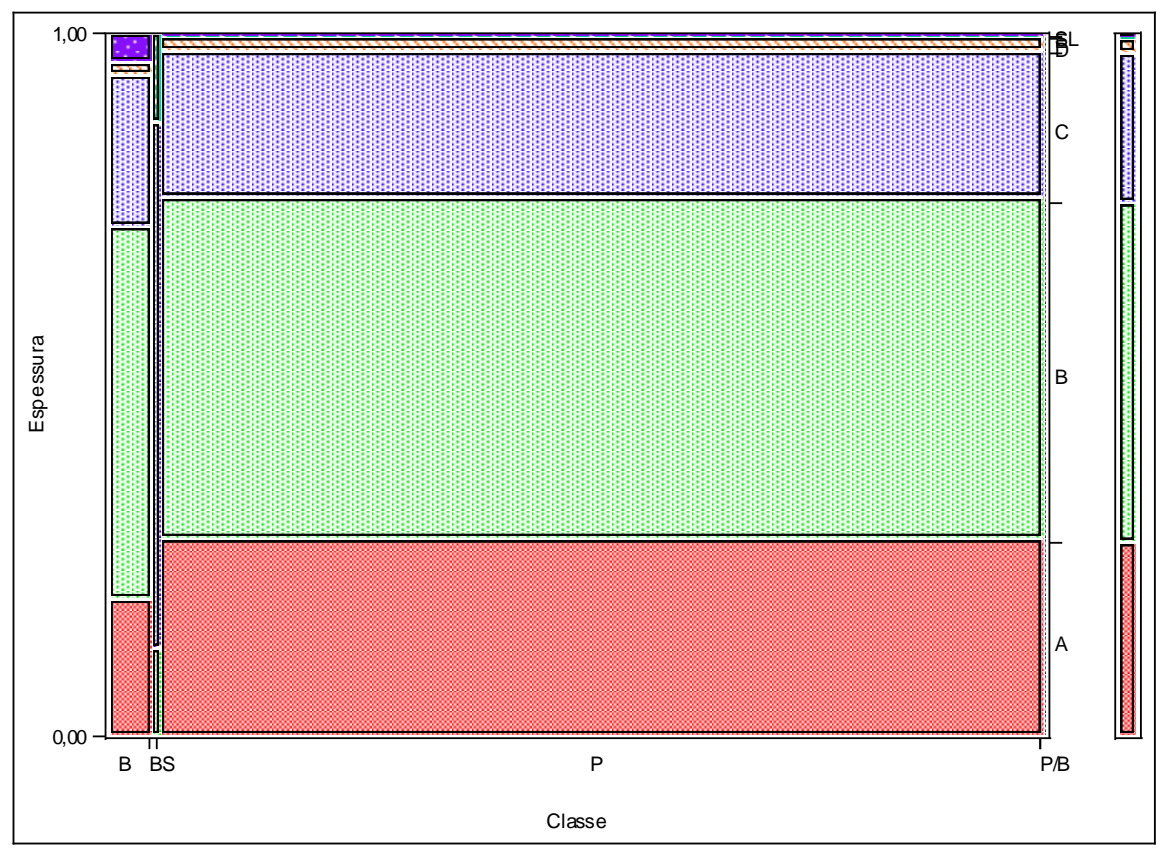

Figura 2.6 - Proporção entre classe e espessura. A - 4 a 8.99 mm, B - 9 a 14.99 mm, C - 15 a 20.99 mm, D - 21 a $26.99 \mathrm{~mm}, \mathrm{E}-27$ a $32 \mathrm{~mm}$ e SL - sem leitura. 
Tabela 2.5 - Distribuição entre classe e espessura

\begin{tabular}{|c|c|c|c|c|c|c|c|}
\hline Classe & $\begin{array}{c}\text { A- } 4 \text { a } \\
8.99 \mathrm{~mm}\end{array}$ & $\begin{array}{c}\text { B - 9 a } \\
14.99 \mathrm{~mm}\end{array}$ & $\begin{array}{r}\mathrm{C}-15 \mathrm{a} \\
20.99 \mathrm{~mm}\end{array}$ & $\begin{array}{r}\text { D - } 21 \text { a } \\
26.99 \mathrm{~mm}\end{array}$ & $\begin{array}{l}\text { E - 27 a } \\
32 \mathrm{~mm}\end{array}$ & $\begin{array}{l}\text { SL (sem } \\
\text { leitura) }\end{array}$ & Total \\
\hline B - borda & 10 & 27 & 11 & 1 & 0 & 2 & 51 \\
\hline BS - base & 0 & 1 & 6 & 0 & 1 & 0 & 8 \\
\hline$P$ - parede & 286 & 493 & 212 & 21 & 1 & 2 & 1015 \\
\hline $\begin{array}{l}\mathrm{P} / \mathrm{B} \text { - parede } \mathrm{e} \\
\text { borda }\end{array}$ & 0 & 0 & 1 & 0 & 0 & 0 & 1 \\
\hline $\begin{array}{l}\text { Total de } \\
\text { fragmentos }\end{array}$ & 296 & 521 & 230 & 22 & 2 & 4 & 1075 \\
\hline
\end{tabular}

A tabela 2.5 aponta a distribuição de espessura por tipo de peça.

Com relação à proporção entre o número geral de fragmentos e quantidade de ocorrências com decoração plástica verifica-se que apenas $16,5 \%$ possuíam esse tipo decorativo (tabela 2.6).

Tabela 2.6 - Distribuição de decoração plástica

\begin{tabular}{ccc} 
Decoração plástica & Quantidade & \% \\
\hline 0 & 3618 & 83,4 \\
1 & 714 & 16,5 \\
Total & 4332 & 100 \\
\hline
\end{tabular}

Segundo Prous (2006), existem características comuns no que diz respeito aos tipos de decoração da cerâmica Tupiguarani. Comumente encontra-se a decoração ungulada em recipientes pequenos, respeitando padrões de movimentos geométricos.

Na figura 2.7 observa-se uma amostra da decoração ungulada do sítio Gramado e, concordando com Prous (2006), a maioria dos fragmentos é de potes pequenos. Além disso, também se observa a variedade desse tipo decorativo, algumas decorações estão somente na borda (figura 2.7 - D e G), enquanto outras se apresentam em todo o fragmento (figura 2.7 - A, B, C, E e F). É possível perceber a simetria das ungulações em quase todos os fragmentos, exceto na figura 2.7 - E, onde a decoração apresenta-se de forma desordenada, tanto no corpo, como na borda. 

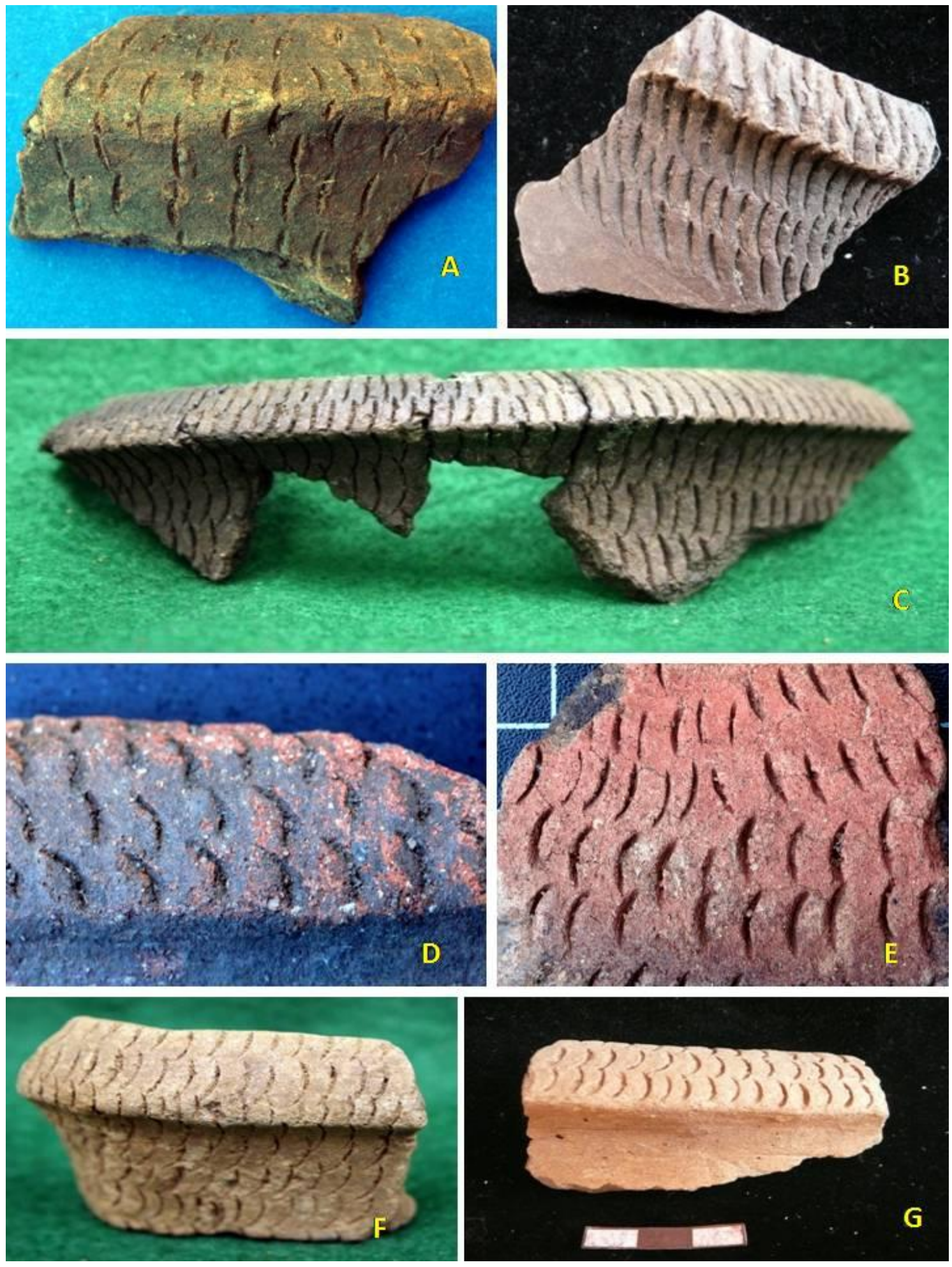

Figura 2.7 - Decoração plástica I. A - Ungulado em linha simétrica perpendicular, B - Ungulado secante, C - Ungulado secante, D - Ungulado tradicional, E - Ungulado assimétrico, F - Ungulado secante e G - Ungulado tradicional. Classificação de La Salvia \& Brochado (1989). 


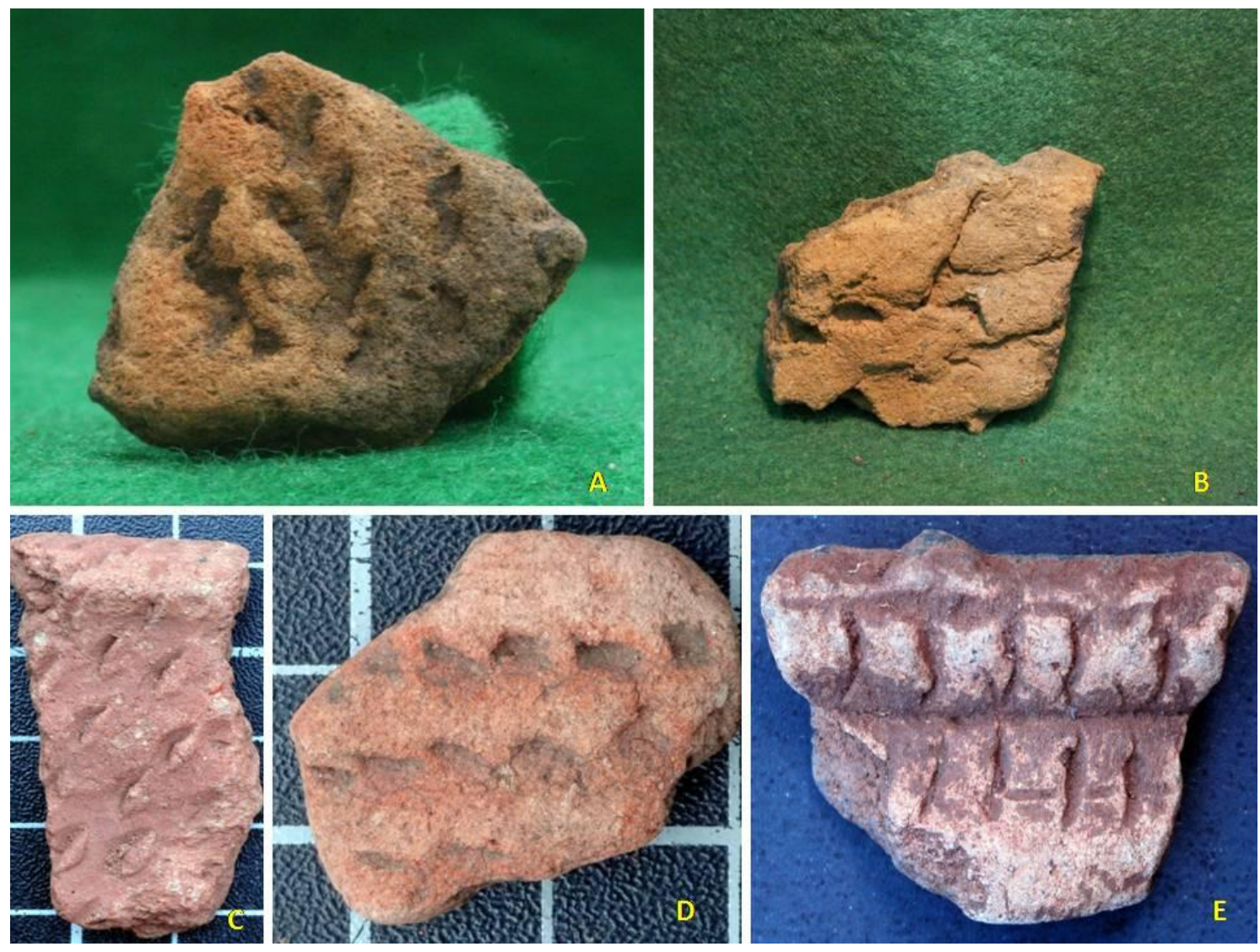

Figura 2.8 - Decoração plástica II. A - Serrungulado; B - Roletado clássico com marcas de corrugado; C - Ungulado perpendicular; D - Ponteado e E - Ungulado associado ao roletado. Classificação de La Salvia \& Brochado (1989).

O corrugado do sítio Gramado, também apresentou muitas variantes, como se vê na figura 2.9. Observou-se a presença de corrugado clássico e perpendicular (figura 2.9 - A, C e D), além da presença de decoração corrugada-ungulada (figura 2.10). Com relação às exceções, verificouse a presença de um fragmento serrungulado (figura $2.8-\mathrm{A}$ ) e outro nodulado aplicado (figura $2.9-\mathrm{E})$.

Segundo Prous (2007), as panelas Tupiguarani recebiam a decoração corrugada, enquanto as igaçabas poderiam apresentar decoração corrugada ou pintada, porém com motivos pouco elaborados. 

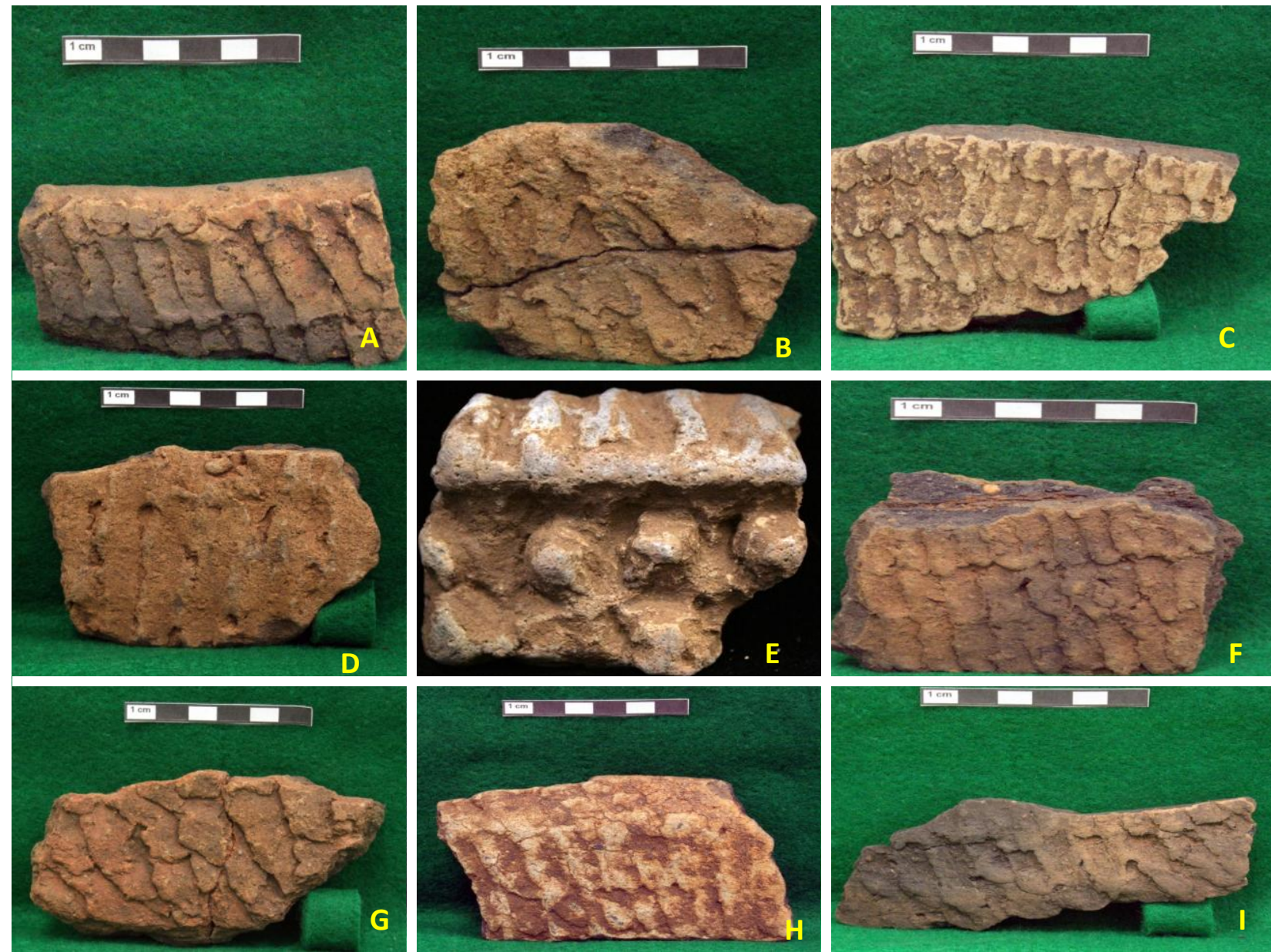

Figura 2.9 - Decoração plástica III. A - Corrugado clássico, B - Corrugado assimétrico, C - Corrugado perpendicular, D Corrugado grosseiro, E - Nodulado aplicado, F - Corrugado perpendicular, G - Corrugado assimétrico, H Corrugado perpendicular e I - Corrugado oblíquo. Classificação de La Salvia \& Brochado (1989).

Na figura 2.10 são apresentados exemplos de cerâmica com decoração corrugadaungulada encontradas no sítio Gramado. Verifica-se que o fragmento A da mesma figura possui decoração corrugada-espatulada (Moraes, 2007). 

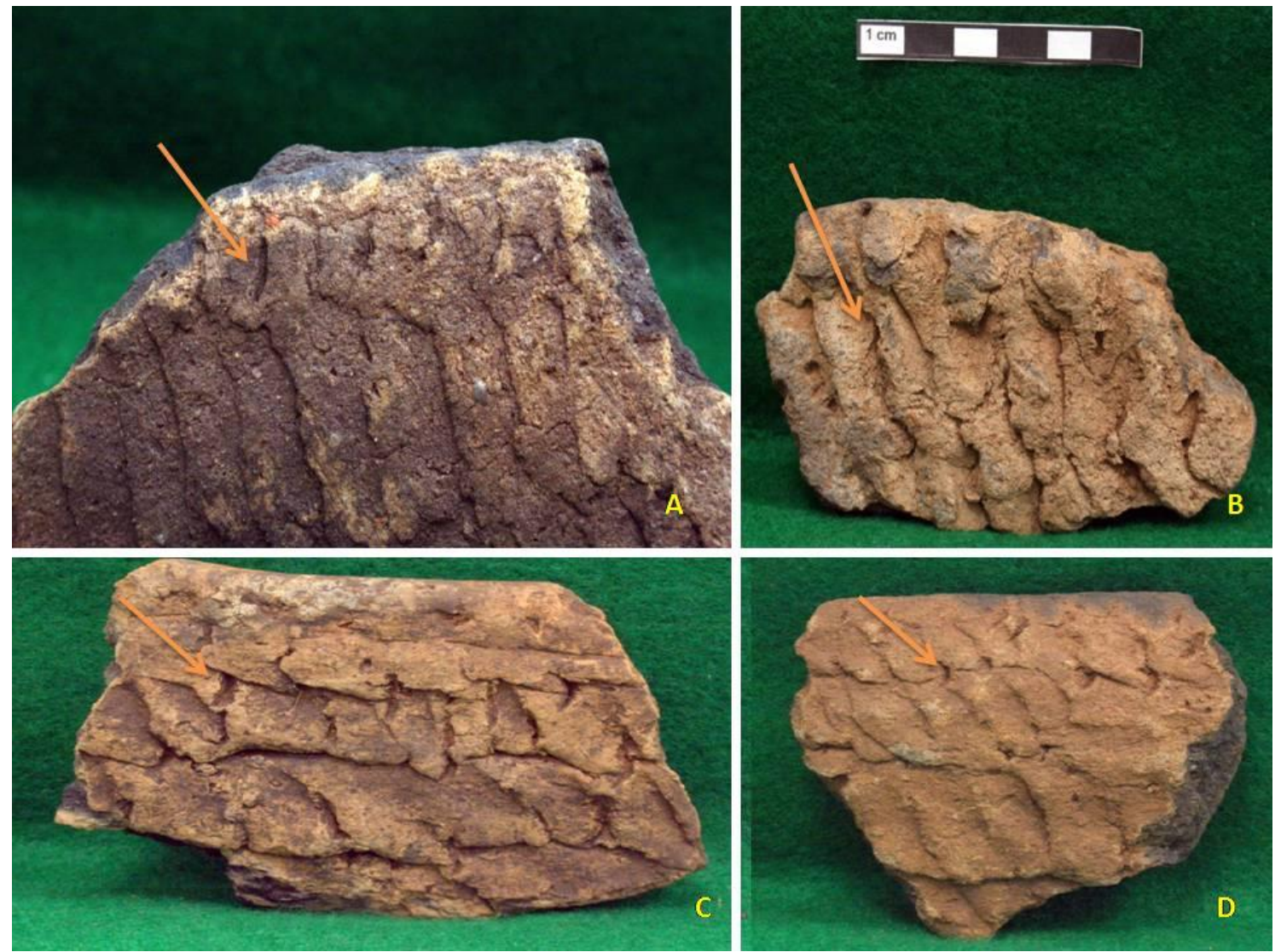

Figura 2.10 - Decoração plástica IV. A - Ungulações entre o corrugado espatulado, B - Ungulações em cima do corrugado clássico, C - Ungulações na parte superior do fragmento com corrugado perpendicular e D - Ungulações sobre o corrugado oblíquo. La Salvia \& Brochado (1989).

Na figura 2.11 observa-se que a maioria dos fragmentos com decoração plástica analisados (141) possuíam espessura entre 9 e $14.99 \mathrm{~mm}$, enquanto apenas um (1) fragmento apresentou espessura entre 27 e $33 \mathrm{~mm}$. Esses resultados aparecem de forma mais detalhada na tabela 2.7 . 


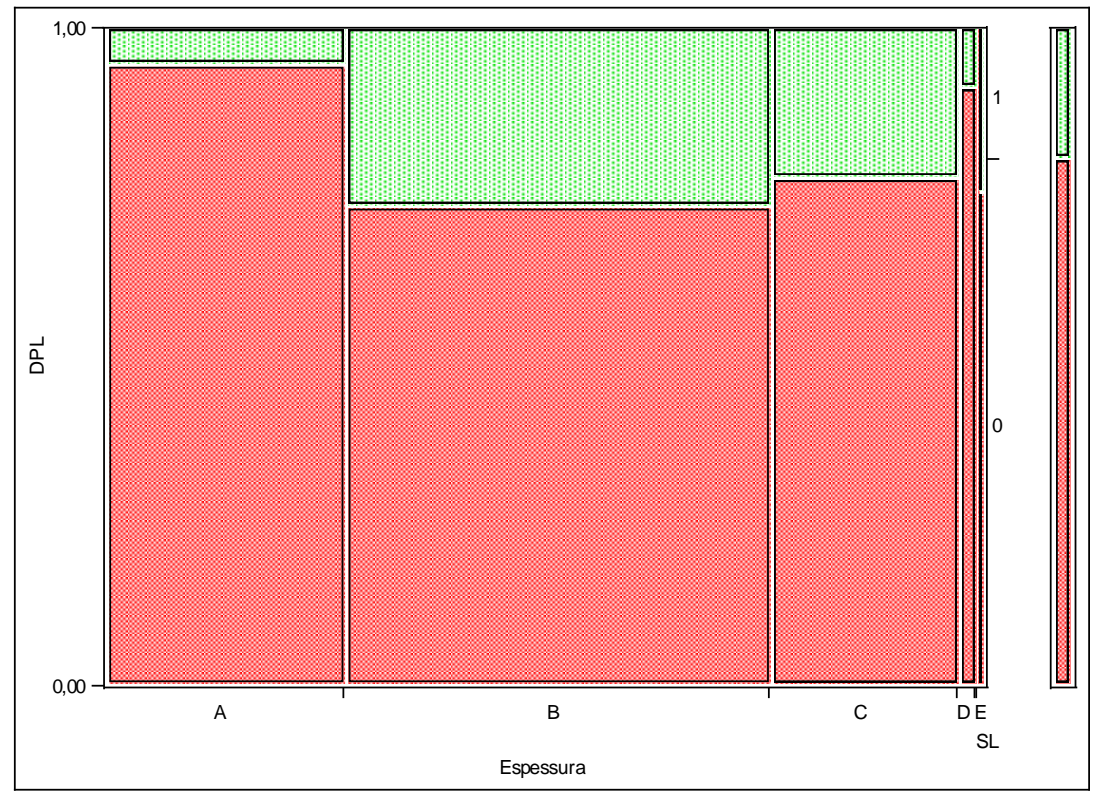

Figura 2.11 - Proporção entre decoração plástica (DPL) e espessura. Vermelho (0) - sem decoração plástica; verde (1) - com decoração plástica. A - 4 a 8.99 mm, B - 9 a 14.99 mm, C - 15 a 20.99 mm, D - 21 a $26.99 \mathrm{~mm}, \mathrm{E}-27$ a $32 \mathrm{~mm}$ e SL - sem leitura.

Tabela 2.7 - Distribuição entre decoração plástica e espessura

\begin{tabular}{lccc}
\multicolumn{1}{c}{ Espessura } & $\begin{array}{c}\text { Sem decoração } \\
\text { plástica }\end{array}$ & Com decoração plástica & Total \\
\hline A - 4 a 8.99mm & 279 & 16 & 295 \\
B - 9 a 14.99mm & 380 & 141 & 521 \\
C - 15 a 20.99mm & 177 & 52 & 229 \\
D - 21 a 26.99mm & 20 & 2 & 22 \\
E - 27 a 32 mm & 2 & 0 & 2 \\
SL (sem leitura) & 3 & 1 & 4 \\
Total de & 861 & 212 & 1073 \\
fragmentos & & & \\
\hline
\end{tabular}

Com relação às cerâmicas com decoração pintada do sítio Gramado, são apresentadas na tabela 2.8 as proporções de peças com decoração pintada e sem essa decoração. Verificou-se que do número total de fragmentos, apenas 277 possuíam pintura.

Tabela 2.8 - Distribuição de decoração pintada

\begin{tabular}{ccc} 
Decoração pintada & Quantidade & $\%$ \\
\hline 0 & 4055 & 93,6 \\
1 & 277 & 6,4 \\
Total & 4332 & 100 \\
\hline
\end{tabular}


Segundo Prous (2007), as grandes vasilhas Tupiguarani possuem quase sempre, além de reforço na borda e fundo redondo, pintura com decoração linear de cor escura, aplicada sobre um fundo branco.

As linhas pintadas da cerâmica Tupiguarani apresentam-se, na maioria das vezes, com linhas duplas e paralelas ou interconectadas com linhas transversais mais curtas (figura 2.14) (Brochado 1981; Prous 1992). Quanto às cerâmicas com decoração exclusivamente pintada, observa-se que a borda costuma apresentar-se reforçada do lado de fora e presença de uma base plana decorada - linhas pretas verticais ou obliquas compondo triângulos.

Na figura 2.12 observa-se um exemplo de fragmento de cerâmica do sítio Gramado com presença de engobo vermelho na face externa.

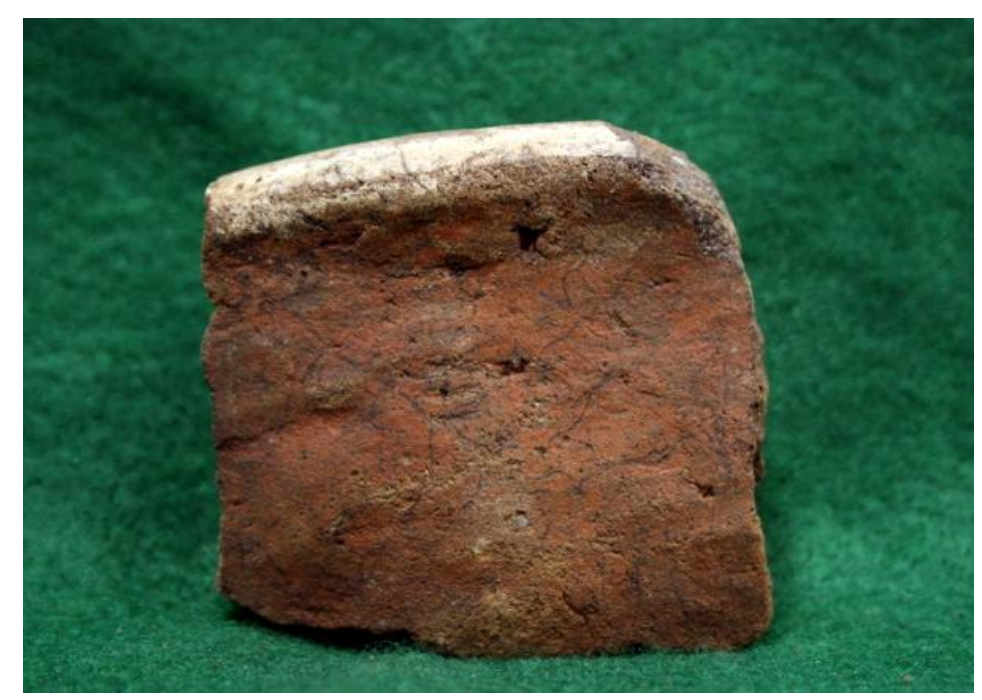

Figura 2.12 - Cerâmica do sítio Gramado (1).

Durante análise de laboratório foi possível remontar seis fragmentos de cerâmica pintada e observou-se com clareza uma extensão maior dos elementos decorativos na face interna: faixa vermelha próxima à borda, desenho em preto com linhas curvilíneas (formando círculos e figuras circulares) sobre fundo branco (figura 2.13). 

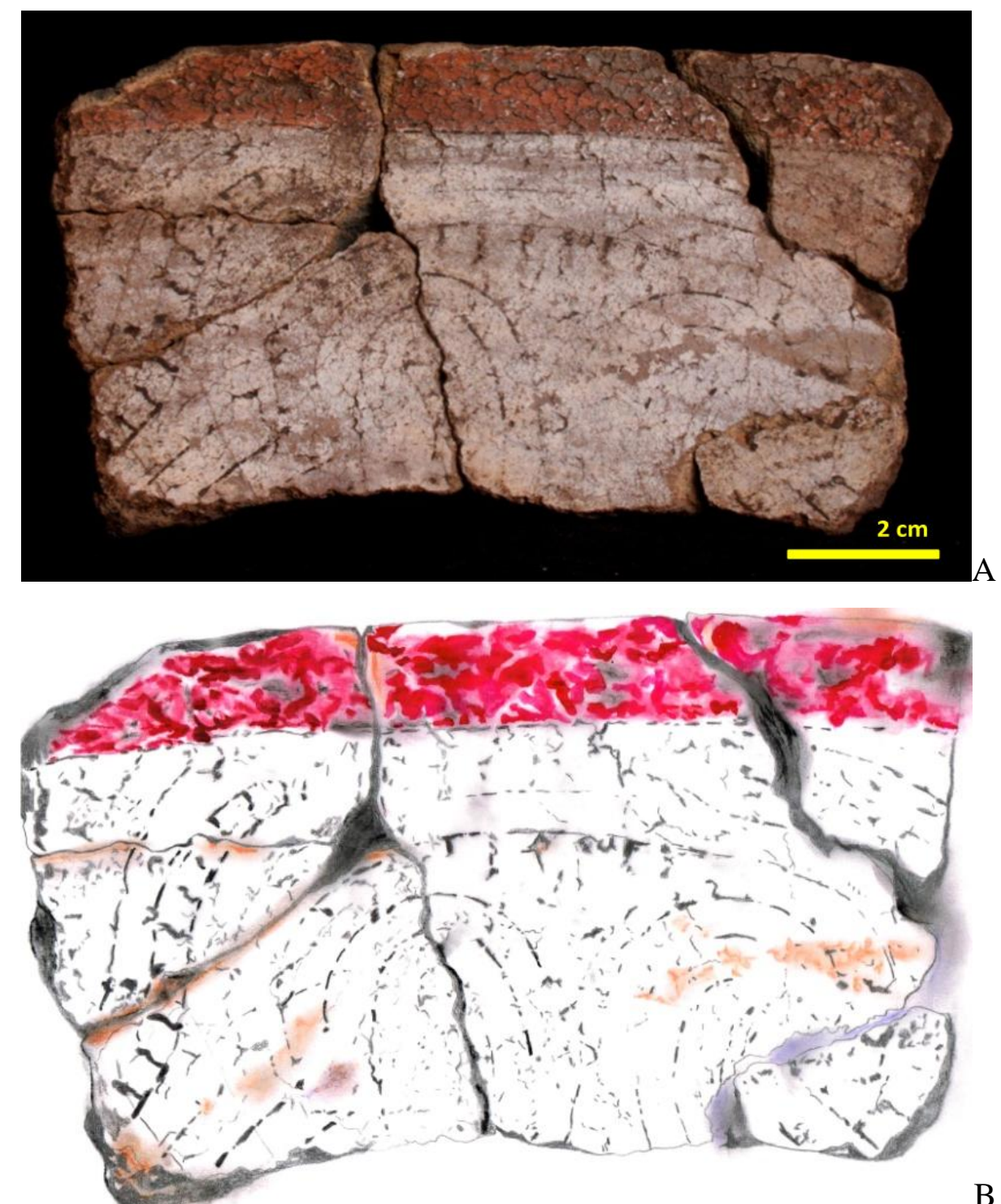

B

Número: GR 3683, 4036, 4039, 4063, 4097 e 4090.

Classe: parede e parte da borda. - Local da pintura: parede e borda. Tipo de linha: retas e curvas. - Orientação da linha: longitudinal. Espessura da faixa: estreita. - Obs.: Apresenta quebra no rolete onde iniciaria a borda.

Figura 2.13 - Cerâmica com decoração pintada. A - Cerâmica pintada, B - Desenho da cerâmica técnica mixta: grafite, aquarela e pastel oleoso. Acervo Museu de Arqueologia e Etnologia da USP. Foto: Marianne Sallum. Desenho: Marianne Sallum.

Na figura 2.14 temos uma amostra de bordas com decoração pintada. Todos os fragmentos apresentam as mesmas características estilísticas: pintura branca no fundo, faixas vermelhas e linhas pretas (algumas retas e outras oblíquas). Segundo Brochado (1981), a presença de faixas vermelhas serve como elemento delimitador ou de acabamento, porém nunca como formador do motivo. 
Marianne Sallum, 2011

Estudo do Gesto em Cerâmicas do Sítio Gramado

\section{Foto}
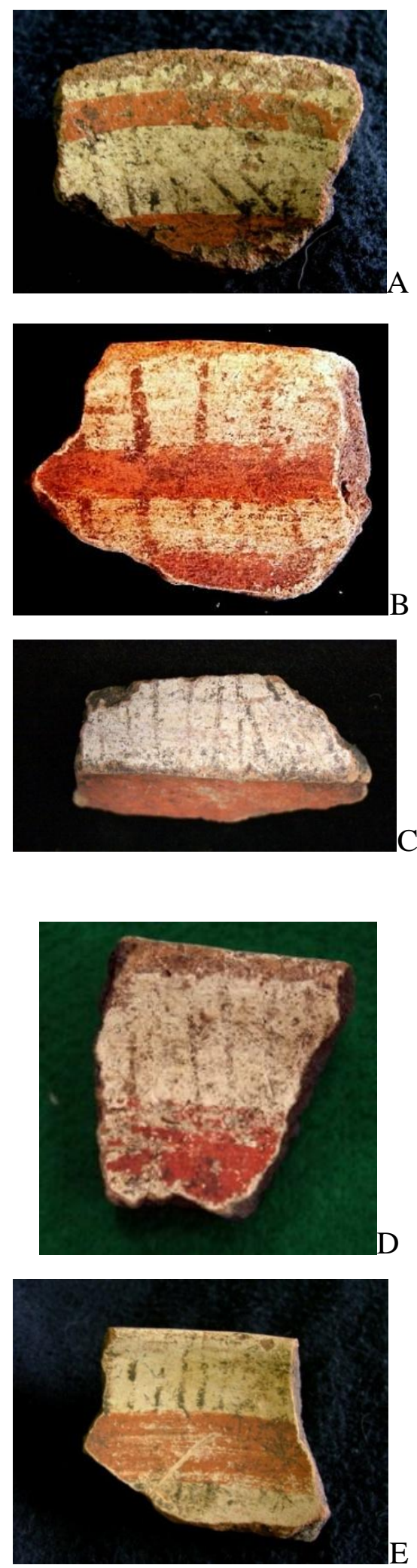

Desenho
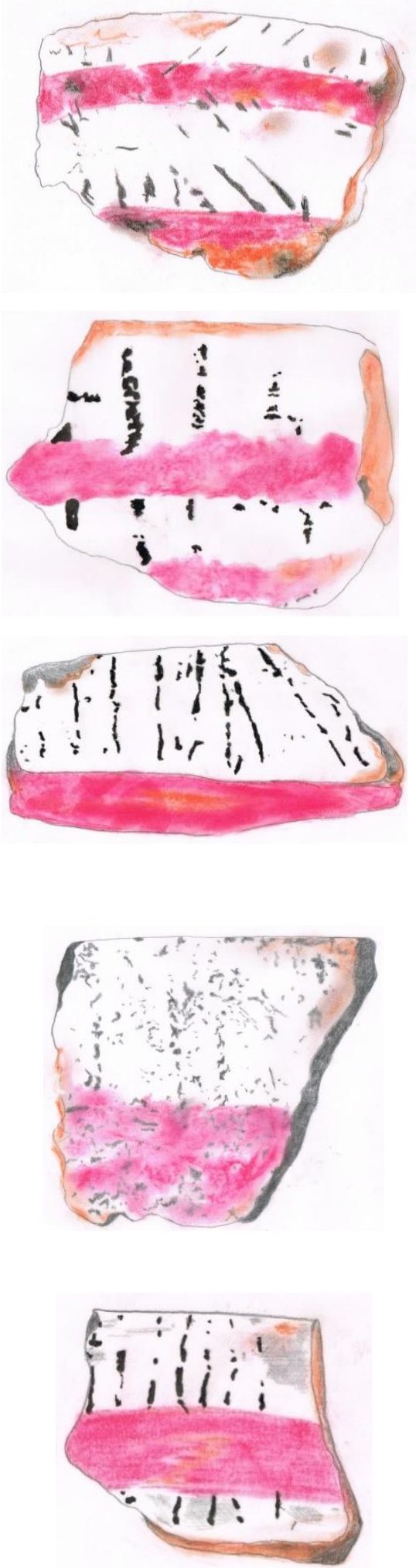

\section{Descrição de atributos}

Local da pintura: parede e borda e lábio.

Tipos de linha: retas.

Orientação da linha: transversal e oblíqua.

Espessura da faixa: fina.

Local da pintura: borda.

Tipos de linha: retas.

Orientação da linha: transversal.

Espessura da faixa: estreita.

Local da pintura: borda.

Tipos de linha: retas e obliquas.

Orientação da linha: transversal com relação à parede.

Local da pintura: borda.

Tipos de linha: retas.

Orientação da linha: transversal.

Espessura da faixa: sem leitura.

Local da pintura: borda.

Tipos de linha: retas.

Orientação da linha:

transversal.

Espessura da faixa: estreita.

Figura 2.14 - Bordas com pintura. Acervo Museu de Arqueologia e Etnologia da USP. Foto: Marianne Sallum. Desenho: Marianne Sallum. 
Na figura 2.15 observa-se o desenho de alguns padrões estilísticos encontrados na cerâmica do sítio Gramado. A maioria dos padrões consiste em linhas retas e faixas vermelhas delimitando as linhas, exceto a figura $2.15-\mathrm{F}$ e $\mathrm{G}$.

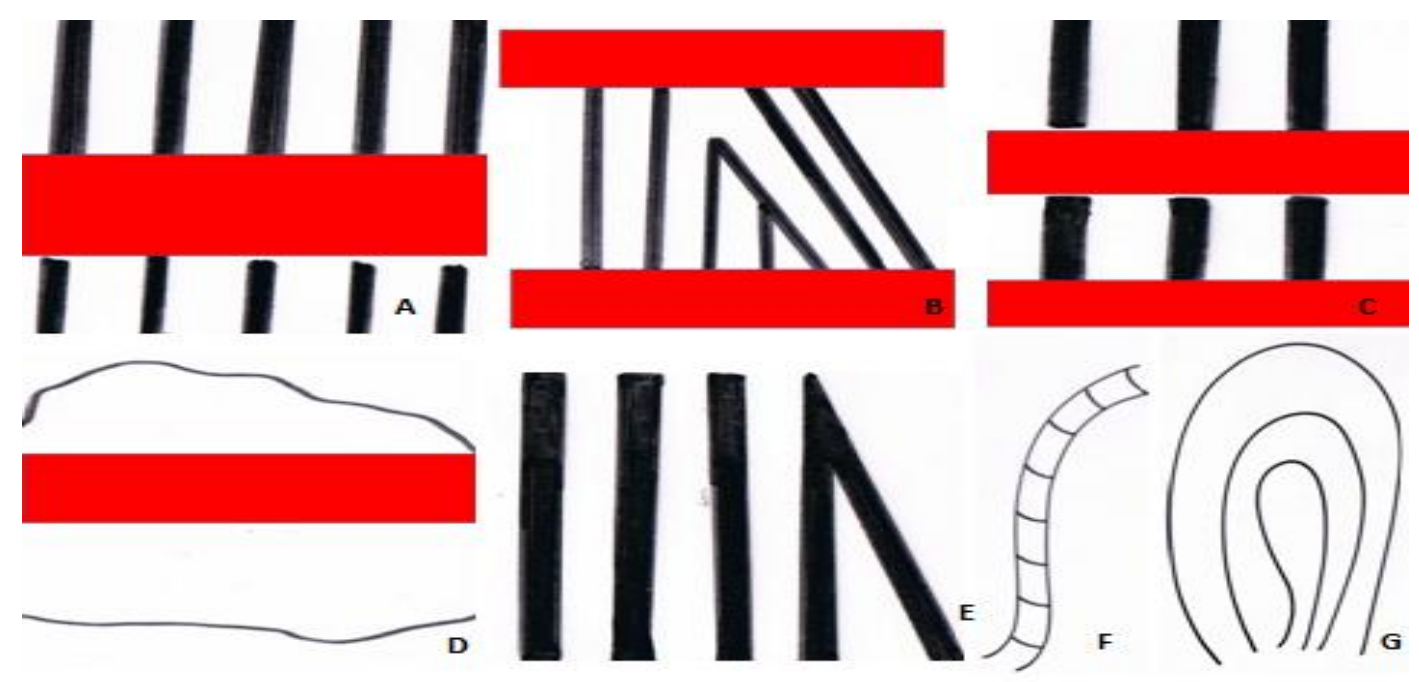

Figura 2.15 - Padrões estilísticos da cerâmica do sítio Gramado. A e C - Linhas pretas e retas, faixa vermelha; B - Linhas pretas retas e oblíquas, faixas vermelhas; D - Faixa vermelha; E - Linhas pretas retas e oblíquas; F e G- Linhas curvas.

Com relação à proporção entre decoração pintada e espessura (Figura 2.9), verifica-se que o número maior de fragmentos encontra-se entre os valores de 9 e 14.99 mm e 15 a 20.99 $\mathrm{mm}$. Vale ressaltar a quase inexistência de fragmentos muito finos ou muito espessos.

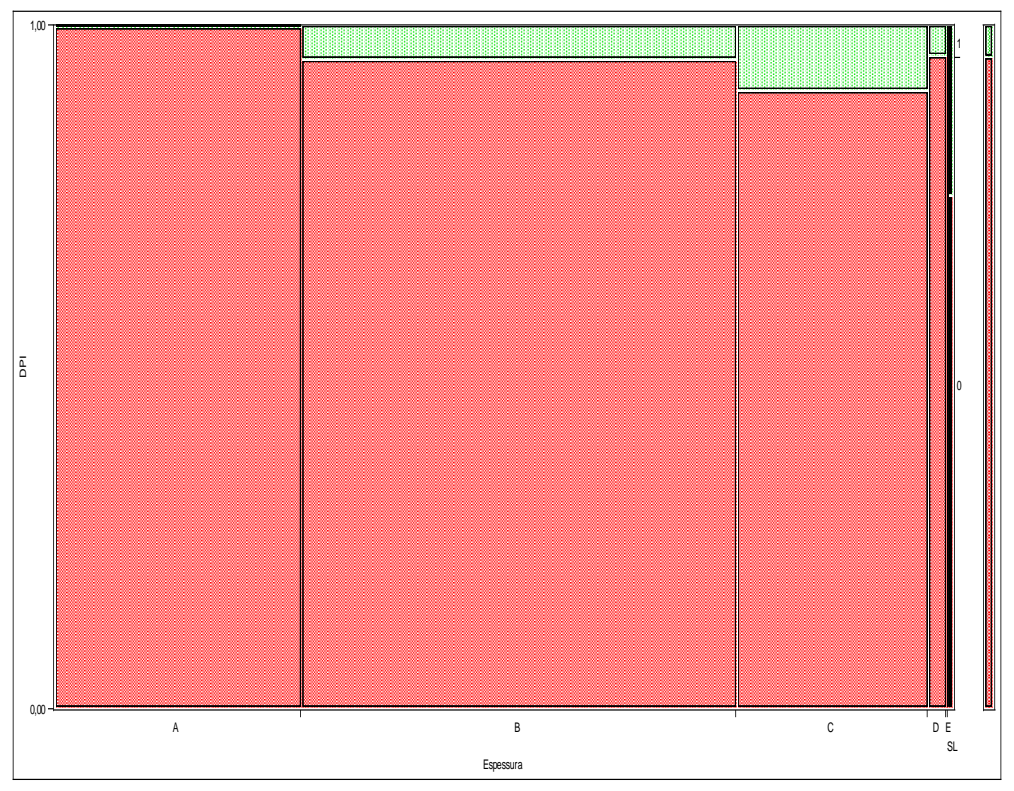

Figura 2.16 - Proporção entre decoração pintada (DPI) e espessura. Vermelho (0) - sem decoração pintada; verde (1) - com decoração pintada. A - 4 a 8.99 mm, B - 9 a $14.99 \mathrm{~mm}$, C - 15 a $20.99 \mathrm{~mm}, \mathrm{D}$ - 21 a 26.99 $\mathrm{mm}, \mathrm{E}-27$ a $32 \mathrm{~mm}$ e SL - sem leitura. 
Tabela 2.9 - Distribuição entre decoração pintada e espessura

\begin{tabular}{lccc} 
Espessura & $\begin{array}{c}\text { Sem decoração } \\
\text { pintada }\end{array}$ & Com decoração pintada & Total \\
\hline A 4 a 8.99mm & 295 & 1 & 296 \\
B 9 a 14.99mm & 495 & 26 & 521 \\
C 15 a 20.99mm & 208 & 22 & 230 \\
D 21 a 26.99mm & 21 & 1 & 22 \\
E 27 a 32 mm & 2 & 0 & 2 \\
SL (sem leitura) & 3 & 1 & 4 \\
Total de & 1024 & 51 & 1075 \\
fragmentos & & & \\
\hline
\end{tabular}

\subsection{Conclusão}

A partir dos dados apresentados podem-se estabelecer algumas conclusões sobre a cerâmica do sítio Gramado. Com relação às características quantitativas temos a presença em maior número de fragmentos de parede, seguidos de bordas e bases. As cerâmicas com decoração plástica são encontradas em maior quantidade comparadas à cerâmica pintada, mesmo considerando a coleta seletiva de bordas.

No que diz respeito à pintura, observa-se a presença de pintura do tipo engobo (realizada antes da queima) nas cores branca, preta e vermelha. Os motivos variavam entre linhas retas, curvas e oblíquas, bem como faixa vermelha fina e estreita delimitando campos. Com relação à cerâmica com decoração plástica, observou-se a presença de decoração corrugada e ungulada, além de um fragmento serrungulado e outro nodulado aplicado.

Estabeleceu-se uma relação entre espessura, classe e tipo de decoração. As paredes e bordas possuíam grande variação de espessura, porém não ultrapassavam $2 \mathrm{~cm}$. Com as cerâmicas decoradas, as pintadas apresentavam espessuras médias, enquanto as plásticas variavam entre muito finas (unguladas) e espessas (corrugadas).

Com relação à técnica de construção dos vasilhames, verificou-se a presença do acordelado, evidenciada pela quebra dos fragmentos no rolete, no qual os roletes não foram alisados de forma a se unirem completamente, assim no momento da secagem e queima acontece rachaduras e quebras. Para a confecção de uma peça utilizando a técnica de acordelamento, os roletes necessitam possuir um diâmetro maior que a parede, para que ocorra sobra de argila que permita uni-los (Mattison, 2004).

Foram encontrados poucos fragmentos de base, porém notou-se uma característica comum entre eles, consiste no alisamento ruim de suas superfícies, deixando em evidencia as 
espessuras dos roletes. A partir da medição dos roletes, pode-se concluir que os fragmentos pertenciam a vasilhames médios ou grandes.

Quanto à classificação de queima, observou-se que a maioria dos fragmentos apresentava núcleo central espesso e escuro, além de camadas oxidadas finas e claras nas extremidades.

A queima com essas características provavelmente foi realizada a céu aberto, método que consiste em colocar as peças em uma fogueira quase apagada para concluir a secagem das peças antes da queima, com isso a argila esquenta por inteira, reduzindo o perigo de rachaduras produzidas pelo vapor dos poros da argila. A partir do momento que a cerâmica seca e sinteriza, acendem-se o fogo até que as vasilhas fiquem cobertas pelas chamas. Na última etapa de queima, alimenta-se o fogo com ramos secos e a cerâmica desprende calor de sua superfície. A duração desse tipo de queima é de menos de uma hora, enquanto uma queima atual em forno a gás dura aproximadamente 7 horas (Rhodes, 1987). 


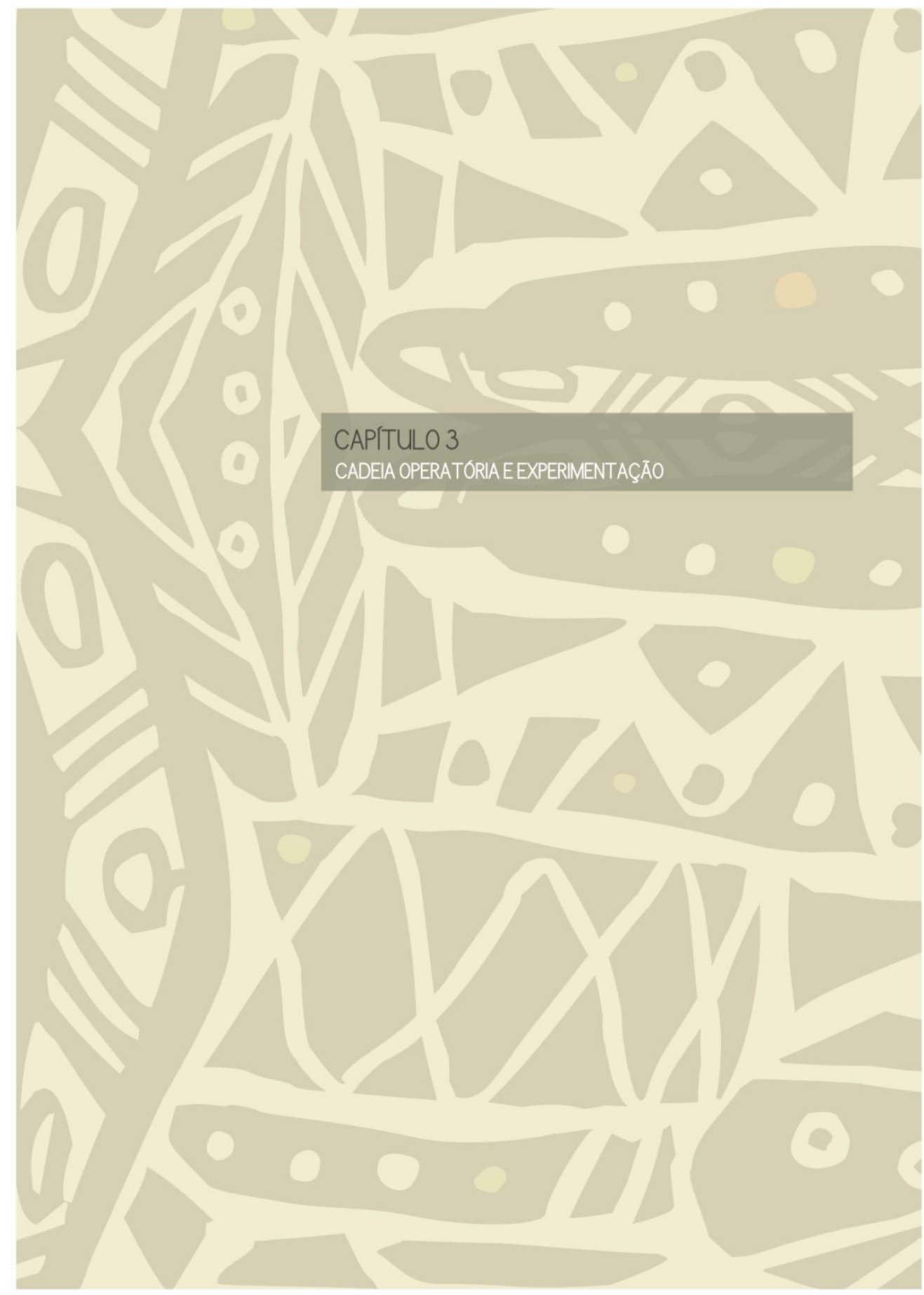




\section{SUMÁRIO}

\section{CAPÍTULO 3 - Cadeia operatória e Experimentação}

\subsection{Introdução}

3.2 Materiais e Métodos

3.3 Resultados e Discussão

3.4 Conclusão

\section{Figuras}

3.1 Materiais e base de pote

3.2 Preparação de roletes

3.3 Desenho e instalação de roletes

3.4 Decoração do pote

3.5 Decoração do pote, brunidura e preparação do antiplástico

3.6 Alisamento de placas e preparação de decorações didáticas

3.7 Processo de secagem e queima, alem de peças já cozidas

3.8 Réplicas e placas com decoração

3.9 Teste de pigmento

3.10 Fragmento de base

3.11 Exemplo de decoração plástica

3.12 Vista do corte de fragmento

3.13 Kit de réplicas de cerâmica arqueológica

\section{Tabela}

3.1 Materiais utilizados na experimentação 


\subsection{Introdução}

"Hecho con las manos, el objeto artesanal guarda impresas, real o metafóricamente, las huellas digitales del que lo hizo. Esas huellas no son la firma del artista, no son un nombre; tampoco son una marca. Son más bien una señal: la cicatriz casi borrada que conmemora la fraternidad original de los hombres. Hecho por las manos, el objeto artesanal esta hecho para las manos: no solo lo podemos ver sino que lo podemos palpar".

Paz, Octavio. El uso y la contemplación. In: Obras completas -edición del autor. México: Ed. Barcelona - Fondo de Cultura Económica, 1994.

Este capítulo é uma abordagem sobre "o estudo do gesto" em material cerâmico do sítio Gramado, localizado no município de Brotas, Vale Médio do Rio Tietê (SP). A arqueologia experimental foi o eixo norteador desta pesquisa que teve como objetivo a reconstrução das etapas da cadeia operatória, desde o processo de manufatura de uma peça até seu descarte, deterioração ou reparação, bem como os processos de pós-manufatura de um fragmento (Skibo, 1992).

Segundo Skibo e Schiffer (2008) os estudos sobre cadeia operatória tiveram vários adeptos entre os antropólogos franceses, como antropólogo Mauss (1974) e o pré-historiador Leroi-Gourhan (1990). O primeiro conceito de cadeia operatória foi estabelecido por LeroiGourhan (1990) e, posteriormente desenvolvido por Balfet (1991) e Cresswell (1972) que contribuíram com o surgimento na França de pesquisas voltadas para o conhecimento de técnicas, tanto na Antropologia, como da Etnologia (Livingstone-Smith, 2010).

Desde o final do século XX, observou-se considerável avanço nos estudos de cerâmica, principalmente no que diz respeito às pesquisas com experimentação. Skibo e Schiffer (2008) apontam para a necessidade de um estudo que relacione não somente os processos de manufatura, mas que valorizem as interações de uso, manutenção, re-uso, deposição, bem como os processos de pós-manufatura.

A pesquisa com experimentação, principalmente com material lítico foi, desde a década de 1960, difundida tanto nos Estados Unidos como na Europa. Pesquisas experimentais com 
relação à queima também foram realizadas nos Estados Unidos buscando aproximar as microestruturas da cerâmica reproduzida experimentalmente com a cerâmica arqueológica (Kingery et al. 1976).

Quanto à funcionalidade da cerâmica, pesquisas realizadas com os potes mais antigos do Planalto do Colorado, nos Estados Unidos, mostram que diferentes atividades como armazenamento, cozimento e fermentação, podem influenciar no delineamento de um pote. Vitelli (1999), analisando potes do Neolítico mais antigo, não encontrou evidências de cozimento em muitos deles e, com isso, inferiu que as vasilhas não tiveram uma função utilitária. Porém, investigando o desenho dos potes e relacionando com as várias pistas contextuais, pôde concluir que as cerâmicas tiveram uma função ritual e foram, provavelmente, usadas por xamãs (Skibo e Schiffer, 2008).

Os resultados obtidos, a partir da experimentação e a remontagem da cadeia operatória, podem oferecer dados preciosos para compreensão funcional de um pote, porém, não devem ser analisadas isoladamente. Destaca-se a importância da interdisciplinaridade nos estudos de Arqueologia, como por exemplo, o desenvolvimento da arqueometria, com a qual foi possível estabelecer critérios mais precisos para definição das etapas da cadeia operatória.

O antropólogo Mauss (1974) escreve sobre a importância de compreender o gesto no ensaio "Noções de Técnica Corporal". Para o autor, o corpo é o primeiro e o mais natural instrumento de trabalho. No entanto, a escolha de um gesto não é algo individual, mas sim o reflexo direto das tradições das quais o indivíduo faz parte, ou seja, é possível identificar hábitos próprios de cada sociedade a partir da maneira como os homens e mulheres servem-se de seus corpos. Mauss (1974) fala-nos da idéia de "Homem total" resultado da junção de elementos sociais, psicológicos e biológicos. Para ele, o individuo é apenas um espelho da sociedade em que faz parte, pois é a partir do indivíduo, que o ato torna-se autorizado e aprovado. Essa idéia é adotada por Silva (2000), que aponta que diversos aspectos do fazer cerâmico, como matériaprima, técnicas, morfologia e decoração, são reveladores de preceitos e valores culturais.

As noções de técnicas corporais de Mauss (1974) foram amplamente utilizadas por LeroiGourhan (1990), que uniu os estudos gestuais com as análises de cadeia operatória, afirmando que o estudo do gesto é imprescindível para conhecer uma tecnologia (Suze, 2009).

No livro “Arqueologia Experimental”, Coles (1973) apresenta uma série de trabalhos de experimentação, com reconstituição de fornos romano-britânicos, e conclui que esse tipo de análise amplia a compreensão dos processos técnicos de manufatura (métodos de construção, 
aparência exterior e condições) usados pelos oleiros e aprofunda o conhecimento do pesquisador de hoje sobre a organização da indústria cerâmica.

Coles (1973) identificou algumas regras básicas para o estudo com experimentação:

1) Para obter um resultado mais confiável é necessário que os materiais utilizados na experimentação correspondam aos da sociedade estudada; 2) Os métodos usados para a reprodução dos materiais devem condizer com a cultura material pesquisada; 3) No processo de experimentação, a tecnologia moderna não deve interferir nos resultados, porém se necessário pode ser usada na compreensão dos materiais e métodos; 4) Deve haver uma definição prévia da extensão da experimentação; 5) É importante a repetição em experimentação; 6) Utilização de uma variedade de procedimentos; 7) O resultado não pode ser considerado como prova absoluta e definitiva; 8) A experiência só tem sentido se avaliada em termos de confiança.

No Brasil há alguns trabalhos com arqueologia experimental, porém realizados por poucas pessoas. Vale ressaltar os trabalhos de Prous et al. (2000) sobre a experimentação com machados pré-históricos no Brasil, bem como as pesquisas de experimentação com a cerâmica Tupiguarani. Destacam-se, também, as pesquisas de Panachuk (2006) e a tese de doutorado de Souza (2008) com material lítico polido brasileiro.

Considerando a importância das pesquisas com experimentação e a carência de abordagens de estudos no Brasil, o objetivo desse capítulo será apresentar um estudo do gesto do oleiro, no que diz respeito aos aspectos técnicos de confecção de um pote, como de seus elementos decorativos da cerâmica do sítio Gramado. 


\subsection{Materiais e Métodos}

O material utilizado como base para a experimentação correspondeu aos 4.332 fragmentos cerâmicos do sítio Gramado, dos quais 200 foram selecionados para uma pesquisa mais aprofundada do gesto. $\mathrm{O}$ critério de seleção identificou fragmentos que possuíam características recorrentes, como tipos decorativos e técnicas comuns, bem como aqueles considerados como peça única no sítio. A pesquisa também incluiu visitas a museus e consultas bibliográficas.

Para o desenvolvimento da experimentação, foram utilizados materiais como: argila, seixos, espátulas de madeira, pigmentos naturais, pincéis, forno a gás para cerâmica, além do espaço físico adequado para a pesquisa com o barro (tabela 3.1).

Quanto aos instrumentos para confecção, decoração e acabamento dos potes, foram escolhidos materiais de fácil acesso na natureza como: água, espátulas de madeira, fragmentos de bambu, seixos, argila queimada moída e argila natural, conforme mostra a figura 3.1.

Argila

Utilizou-se uma argila terracota proveniente de São Paulo (Itapeva), composta pela mistura de argilas diferentes moídas misturadas a bentonita proveniente do Estado da Paraíba (nordeste do país).

A palavra terracota é de origem italiana e quer dizer terra cozida. Este tipo de argila possui em sua composição óxido de ferro e é por esse motivo que a sua cor é avermelhada. O óxido de ferro contribui para que a argila seja cozida em baixa temperatura abaixo de $1200{ }^{\circ} \mathrm{C}$, além disso, é um barro resistente ao choque térmico e a presença de fogo direto (Mattison, 2004).

Bentonita é uma mescla de argilas com grãos muito finos e, forma-se, geralmente, por alterações de cinzas vulcânicas ricas em ferro. A argila utilizada na experimentação contém 15\% de caco moído (fragmentos cerâmicos misturados à pasta) e é considerada muito plástica para modelar.

A escolha desta argila deu-se por dois motivos: por possuir a mesma coloração dos fragmentos do sítio Gramado e pela possibilidade de queima em temperatura relativamente baixa $\left(700^{\circ} \mathrm{C}\right.$ até $1200{ }^{\circ} \mathrm{C}$ ), em oposição do que é considerada cerâmica de alta temperatura (acima de $\left.1200{ }^{\circ} \mathrm{C}\right)$. 


\section{Instrumentos}

Foram testados vários instrumentos, tanto para a confecção de formas, como para os elementos decorativos, como: ripas de madeira de diversas espessuras, fragmentos de bambu, seixos de diferentes tamanhos (figura $3.1-\mathrm{A}$ ).

\section{Pigmentos}

Foram utilizados pigmentos naturais (argila colorida) provenientes de São Paulo (Itapeva), bem como pigmento de terra vermelha da cidade de Pirua no Peru e cristais de hematita moída de Matozinhos (Minas Gerais)

Tabela 3.1 - Materiais utilizados na experimentação

\begin{tabular}{ccc} 
Material & Características & Finalidade \\
\hline Argila & Terracota & Argila muito plástica \\
Instrumentos & Seixos e ripas de madeira, & Alisar, brunir e decorar \\
& segmentos de bambu & \\
Pigmentos & Argila colorida & Pintura \\
\hline
\end{tabular}

\section{Forno}

Para a queima, utilizou-se um forno moderno com tijolos refratários e tocha de gás liquefeito de petróleo (GLP) sem compressão de ar, em temperatura variável entre 700 a $900^{\circ} \mathrm{C}$.

Definiu-se como método de trabalho a realização de experimentações de aspectos formais e decorativos dos fragmentos cerâmicos do sítio Gramado, bem como o processo de secagem e queima da argila. Durante a pesquisa, também foram realizadas réplicas de cerâmica arqueológica Aratu e Tupiguarani, que serviram como termo comparativo e material educativo em museus (Figuras 3.7 A, B, E, G-H e 3.8 A, D e F).

A escolha da argila respeitou critérios, como: plasticidade, temperatura de maturação, coloração e cozedura.

Para medir a plasticidade da pasta foram feitos roletes, observando como se comportavam quando eram curvados, quando eram enrolados ou pressionados, e assim foi possível ter a dimensão da deformação ou da resistência da peça antes do cozimento (Mattison, 2004).

As peças passaram pelo processo de secagem em temperatura ambiente que variou entre um e três dias. O tempo foi determinado pela quantidade de água presente na argila, além das 
condições climáticas do momento. Quando secas, as peças entravam no forno e a queima ocorreu de forma lenta e gradativa.

As peças secas à temperatura ambiente continuam a apresentar umidade e, somente quando no forno em temperatura de $100^{\circ} \mathrm{C}$ que ocorre a evaporação completa da água de constituição física. A água de constituição química irá evaporar somente numa temperatura de $550^{\circ}$ C. Só nessa fase que a argila passa por uma transformação irreversível, transformando-se em cerâmica, portanto a contração volumétrica da argila acontece tanto durante a secagem, como durante a queima (Chavarria, 1999).

Para compreender a temperatura de maturação da argila é necessário conhecer qual a elevação máxima de temperatura que a argila necessita chegar para ter sua cozedura correta, ou seja, antes disso o material encontra-se muito poroso e sem sua coloração final (Chavarria, 1999). Para entender esse processo, realizou-se a queima de um fragmento arqueológico do sítio Gramado num forno a gás com temperatura a $980^{\circ} \mathrm{C}$.

A argila terracota atinge seu cozimento entre as temperaturas de $700^{\circ} \mathrm{C}$ a $1200{ }^{\circ} \mathrm{C}$, consideradas como queima de baixa temperatura. Uma característica desse material é que se podem observar efeitos brilhantes derivados de óxidos, impossíveis de ser observados em temperaturas altas (Casson, 1991).

No processo de queima, o aquecimento do forno deve acontecer de forma gradativa, bem como seu esfriamento, permitindo que o calor escape do forno até atingir a temperatura ambiente (Rhodes, 1987).

\section{Antiplástico}

O antiplástico é o material adicionado intencionalmente ou não de algum elemento que melhore as propriedades do barro, como: folhas, palha, areia, rocha, caco moído entre outros.

A discussão sobre o antiplástico está presente na arqueologia desde a década de 1960 e alguns pesquisadores definem como todo material não plástico encontrado na argila e que possui a finalidade de dificultar que as peças sofram rachaduras ou quebras durante a secagem e queima (Moraes, 2007). A peça cerâmica diminui de tamanho desde o momento de sua confecção até a cozedura, porém com o uso adequado do antiplástico e argila pode-se evitar uma deformação do objeto. As cerâmicas mais plásticas possuem partículas menores e sofrem maior contração (encolhimento) durante a secagem e queima (Chavarria, 1999).

O chamote consiste no barro cozido e moído em diferentes graus, conforme se observa na Figura 3.5 - E, F, na qual se triturou a cerâmica num almofariz de pedra antes de misturá-la à 
argila. O chamote exerce duas funções fundamentais: melhorar a consistência da argila e contribuir para aumentar à resistência a deformação (Mattison, 2004).

\section{Etapas da experimentação}

\section{Preparação da argila}

Para iniciar o trabalho com o barro é necessário amassá-lo, a fim de eliminar bolhas de ar e deixar a massa com uma textura uniforme. $\mathrm{O}$ ar contido em bolhas se expande na queima, quebrando as peças. Este processo contribui para perda de água da argila. Primeiramente, separase um pedaço de argila em duas partes e junte-os energicamente, repetindo esse movimento por cinco minutos (figura 3.1 - C). Em seguida, coloca-se a argila em contato com uma mesa ou tronco (preferencialmente um material absorvente como a madeira), de maneira a permitir que as bolhas de ar estourem quando a argila é apertada. O movimento de amassar é lento e rítmico, e consiste em levar a argila de dentro para fora e vice versa (Casson, 1991) (figura 3.1 - B).

\section{Técnica de confecção}

Foram utilizados dois métodos para a confecção de um pote: modelado e acordelado (La Salvia e Brochado, 1989). O modelado foi utilizado para a confecção de bases e consiste em fazer uma esfera de argila e, com o dedo polegar, fazer um orifício no centro dessa esfera, construindo uma base para inserir os roletes (figura 3.1 - E e D). O acordelado consiste na técnica de enrolar cordéis com a mão, um a um ou vários juntos a fim de construir o corpo de uma peça (figura 3.2). Os cordéis devem ter um diâmetro pouco maior que a parede da peça para sobrar argila na união dos roletes. Antes de iniciar a confecção de um pote, deve-se ter em mente a sua forma, pois a posição dos roletes na parede depende do formato que se quer dar a peça. A união dos roletes também é uma etapa importante, pois disso dependerá a presença de rachaduras e quebras nas junções. Muitas vezes é preciso deixar a argila endurecer um pouco para continuar a agregar os cordéis e, assim, evitar que o peso do barro úmido derrube a parede (Mattison, 2004).

Para confecção de réplica de cerâmica arqueológica utilizou-se de gabaritos de papel com a silhueta da peça a ser construída. O procedimento consistiu em encaixar a base modelada no molde e, com isso controlar a forma do pote (figura 3.3 - A). 


\section{Decoração}

As técnicas de decoração consistiam na utilização das mãos, além de ferramentas de madeira, bambu e seixos. Algumas decorações foram realizadas simultaneamente com a construção da forma do vasilhame, ou seja, durante o alisamento dos roletes, deixaram-se texturas impressas nas paredes. Antes da queima podem-se utilizar técnicas diferentes de decoração, dependendo da etapa de dureza que se encontra a pasta. Quando a argila está úmida até atingir o "ponto de couro" é o melhor momento para realização das decorações plásticas, pois a argila encontra-se com a plasticidade adequada para a aplicação da decoração.

No entanto, a aplicação dos pigmentos deve ser realizada no momento em que a argila atinge o "ponto de couro" - etapa em que argila não está mais tão plástica, mas também não totalmente seca (figura 3.4) (Casson, 1991).

Para pintura, utilizou-se da técnica de aplicação de engobo, que consistiu na aplicação de argila dissolvida com água, variando entre aguada e espessa a fim de dar acabamento ou criar linhas. Os óxidos metálicos presente na argila utilizada para confecção do engobo possibilitam uma variedade de cores. O engobo é aplicado na parede do pote antes da secagem completa e queima (Casson, 1991).

Foi realizada experimentação com uso de pigmento após a queima, aplicando óxido de ferro em uma peça cerâmica (figura 3.9).

Esta dissertação entende como pintura toda aplicação de pigmento na peça antes da queima, portanto usando a técnica denominada "engobo", desde aqueles utilizados como tratamento de superfície, bem como os pigmentos aplicados para criar motivos.

A brunidura é utilizada quando a argila está no "ponto de couro". Durante a experimentação, foram usados seixos muito lisos para polir a superfície da argila (figura 3.4). Quando os potes recebem pigmento, a brunidura é feita sobre a pintura e antes da queima (Casson, 1991).

Foram confeccionadas também placas com decoração plástica e pintada que serviram como parte de "kits" de material educativo encomendados pela empresa de consultoria "Zanettini Arqueologia" (figuras 3.7 e 3.8 - C e D).

\section{Secagem}

Para secagem, as peças foram colocadas numa área aberta, porém sem incidência direta da luz do sol no local. Os potes permaneceram de um a três dias expostos dependendo da temperatura ambiente e da quantidade de água presente na argila. Na figura 3.7 - A observam-se 
peças em processo de secagem, onde é possível verificar partes do mesmo pote com coloração mais escura, o que significa que são áreas com maior presença de água.

\section{Queima}

O princípio da queima consiste em administrar o calor no forno durante um período de tempo pré-determinado, gerando mudanças químicas e físicas na pasta cerâmica.

Para essa etapa da pesquisa utilizou-se um forno a gás que possuia indicadores de temperatura e cones pirométricos, possibilitando controlar (quase totalmente) as mudanças de temperatura durante a queima (Mattison, 2004). O tempo médio de cozedura foi de sete horas e o de resfriamento mais sete horas (figura $3.7-\mathrm{B}$ ).

A queima foi analisada levando em conta características físicas da cerâmica como: a cor, a porosidade e a textura, além de aspectos mecânicos relacionados à dureza e resistência.

Foi realizada uma queima de fragmento arqueológico do sítio Gramado por sete horas, em forno moderno e em temperatura de $980^{\circ} \mathrm{C}$. 
Marianne Sallum, 2011

Estudo do Gesto em Cerâmicas do Sítio Gramado
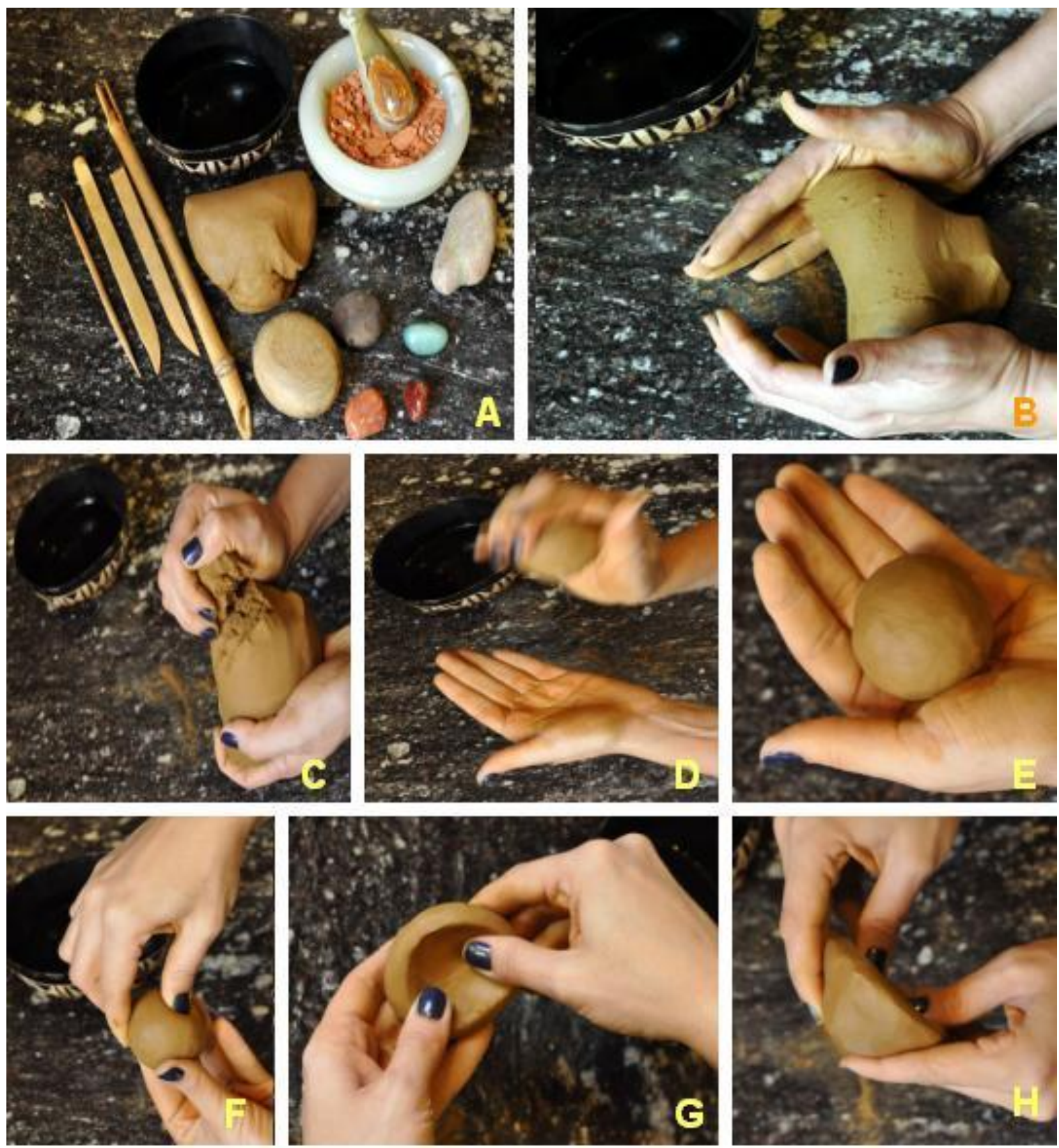

Figura 3.1 - Materiais e base de pote: A - Almofariz para moagem do antiplástico, cuia com água, seixos diversos, palitos de madeira e bambus, argila. B- Barro sendo amassado. C - Retirada de argila do núcleo. D e E - Esfera de argila. $\mathrm{F}, \mathrm{G}$ e $\mathrm{H}$ - Modelagem de forma inicial. 

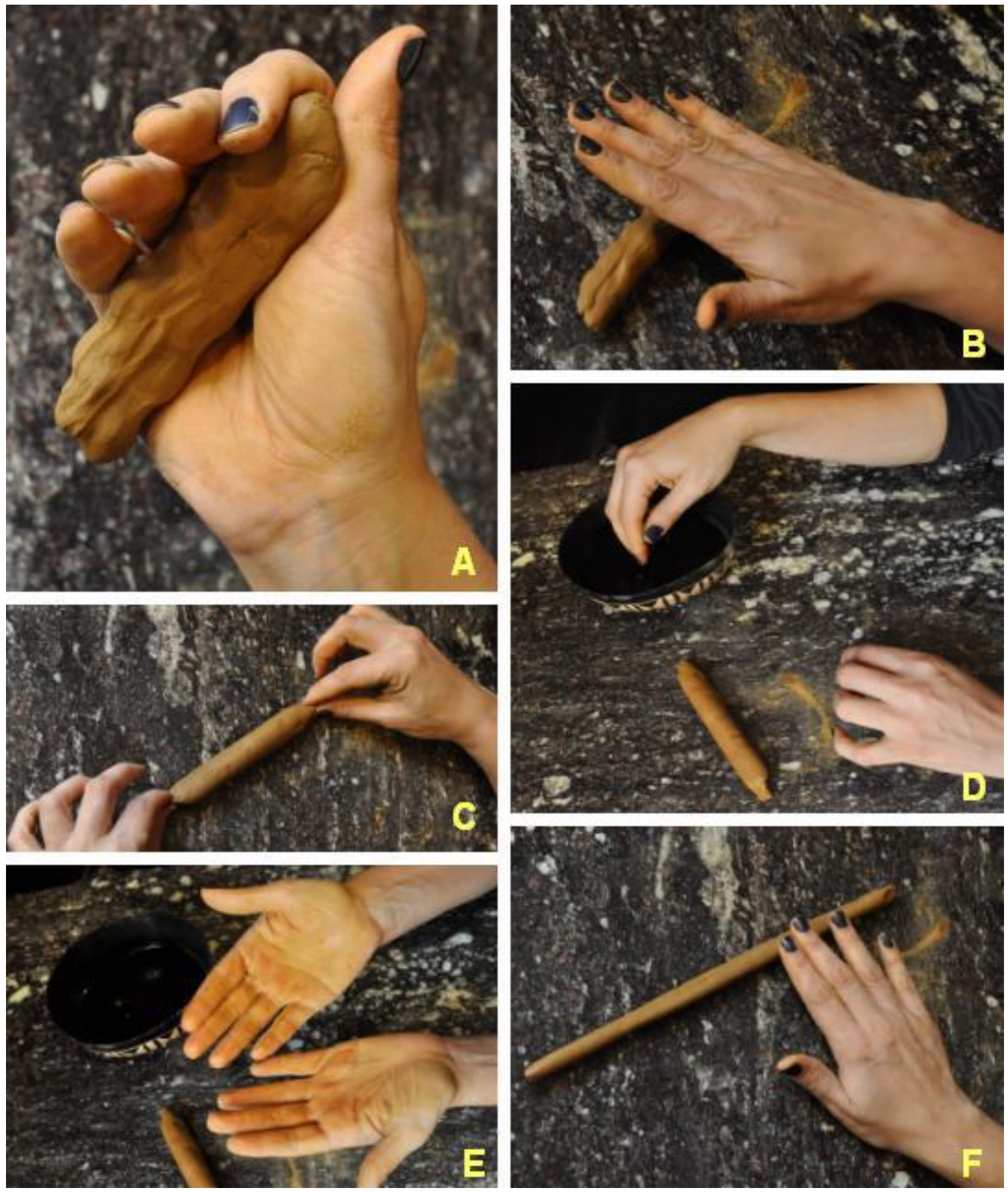

Figura 3.2 - Preparação de roletes. A - Argila amassada com formato que contribua para confecção do rolete. B - Inicio do rolete. C - Pressionando as bordas do rolete para evitar que argila torça internamente. D e E - Mãos umedecidas para a confecção do rolete. F - Rolete sendo alongado uniformemente. 
Marianne Sallum, 2011
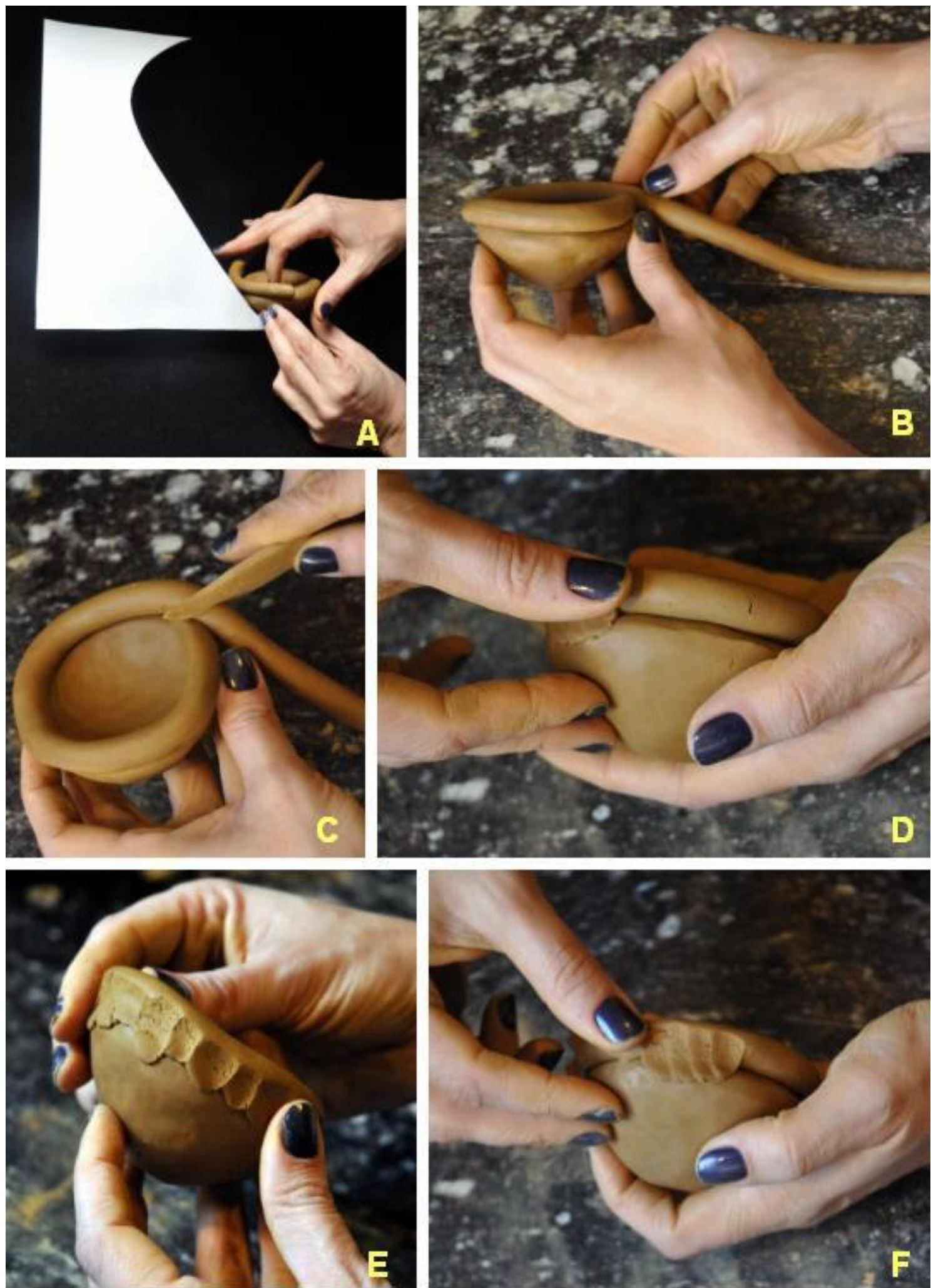

Figura 3.3 - Desenho e instalação dos roletes: A - Gabarito de papel com o formato da peça a ser realizada e sua base de argila. B - Primeiro rolete sob uma base modelada. C - Segmento de madeira cortando excesso de argila do rolete. D - Junção do primeiro rolete com a base, realizada com movimentos uniformes e na mesma direção, do rolete para a base. E e F - Junção dos roletes. 
Marianne Sallum, 2011

Estudo do Gesto em Cerâmicas do Sítio Gramado
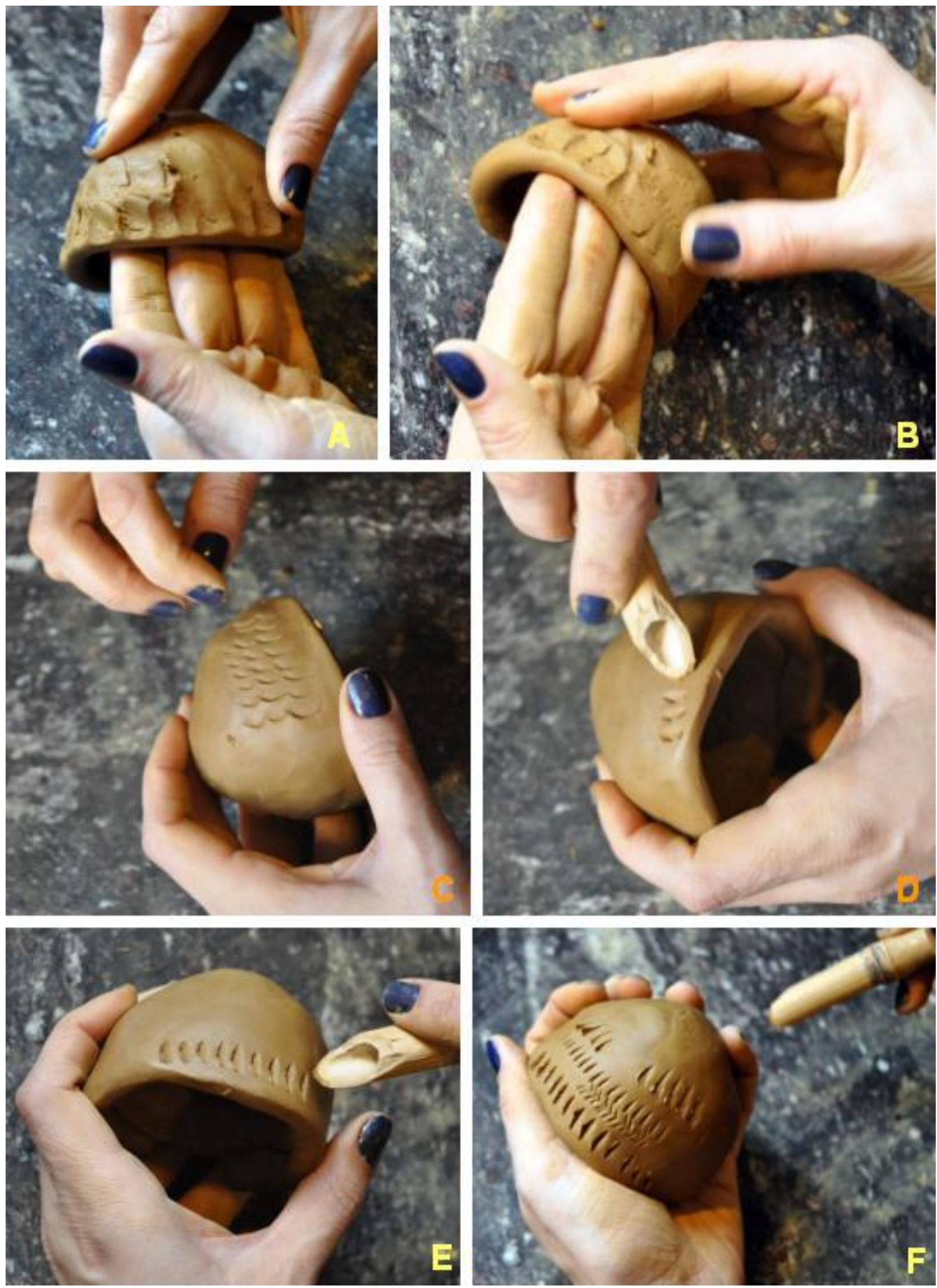

Figura 3.4 - Decoração do pote: A e B - Alisamento do rolete com a base. C, D, E e F - Teste de materiais para a decoração plástica. 
Marianne Sallum, 2011

Estudo do Gesto em Cerâmicas do Sítio Gramado
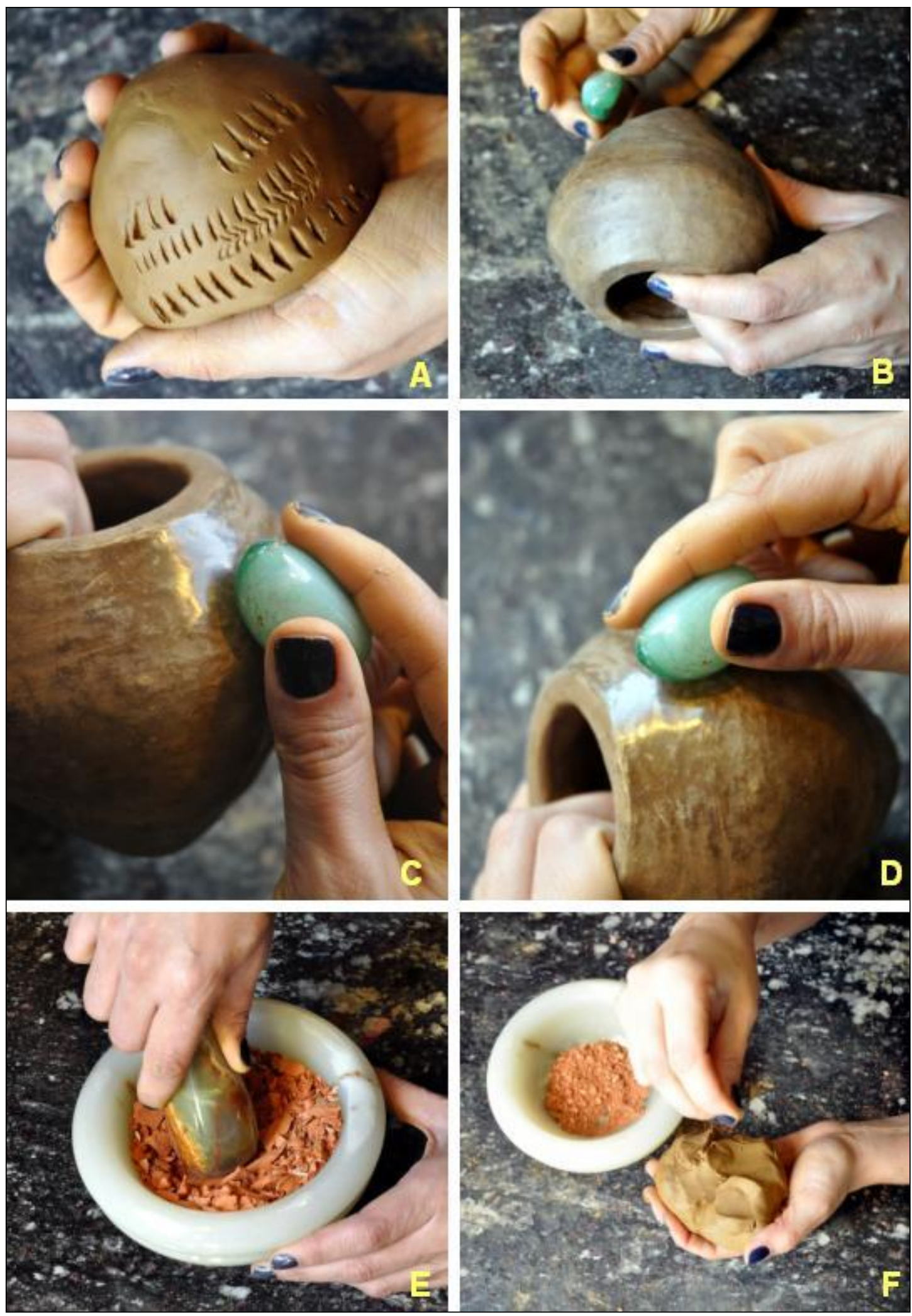

Figura 3.5 - Decoração de pote, brunidura e preparação de antiplástico: A - pote com testes de decoração plástica. B - Inicio de polimento. C e D - Cerâmica sendo triturada para confeccionar o antiplástico (caco moído). F - Antiplástico adicionado a pasta. 

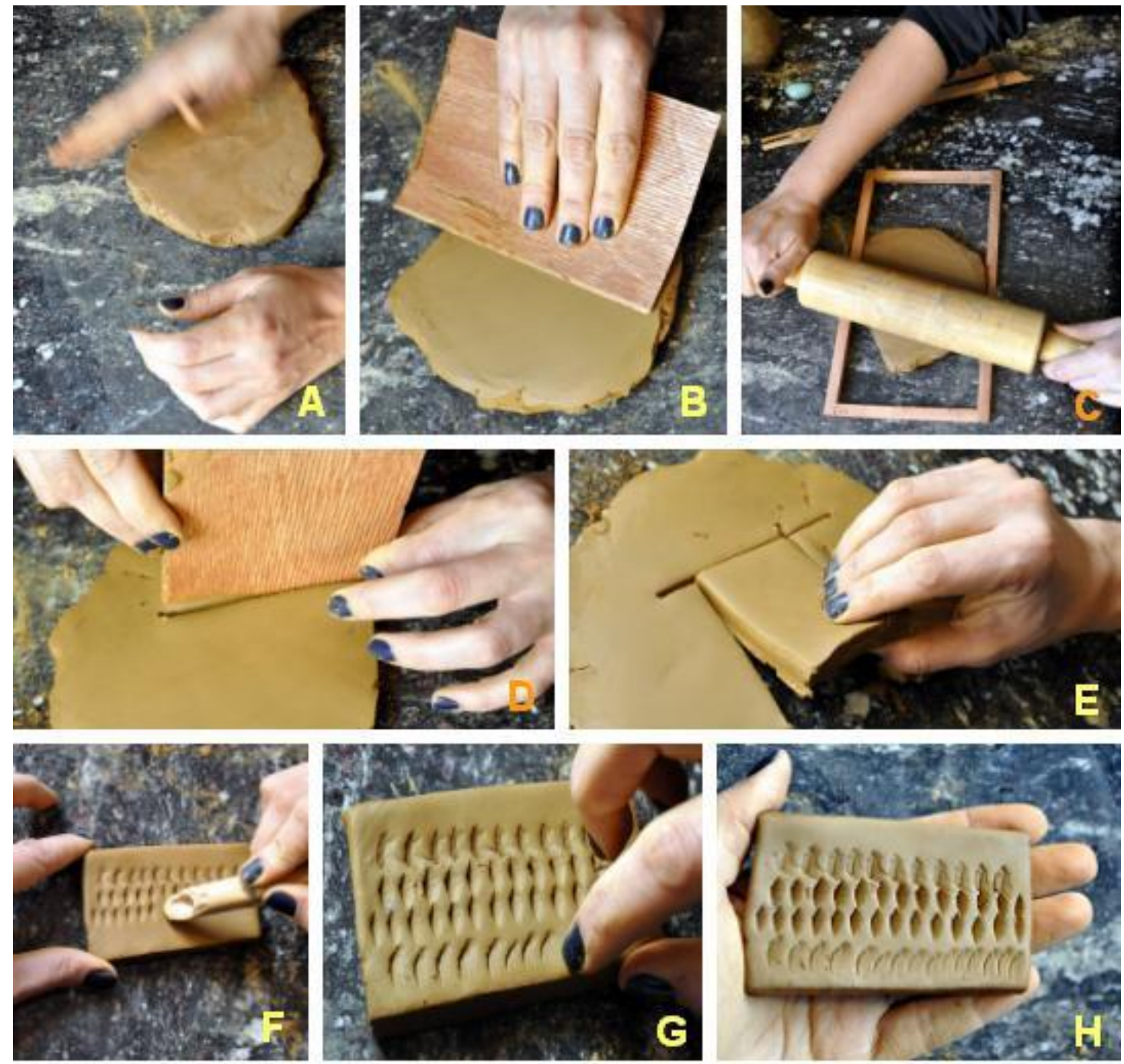

Figura 3.6 - Alisamento de placas e preparação de decorações didáticas: A e B - Confecção de chapa de argila. C, D e E - Utilizando um rolo de macarrão e um chassi de madeira a fim de construir uma chapa uniforme. F, G e H - Exemplos de decoração plástica testados com diversos materiais.

\section{Material educativo}

Paralelamente às pesquisas com experimentação, realizou-se uma série de réplicas de cerâmica arqueológica Tupi e Aratu, que foram utilizadas como material educativo em museus (figura 3.7). Para tanto, criaram-se placas de cerâmica como amostras de decoração pintada e plástica (figura 3.7 - C, D), bem como potes inteiros deixando em evidência a técnica de acordelamento (figura $3.7 \mathrm{G}-\mathrm{H}$ ). 

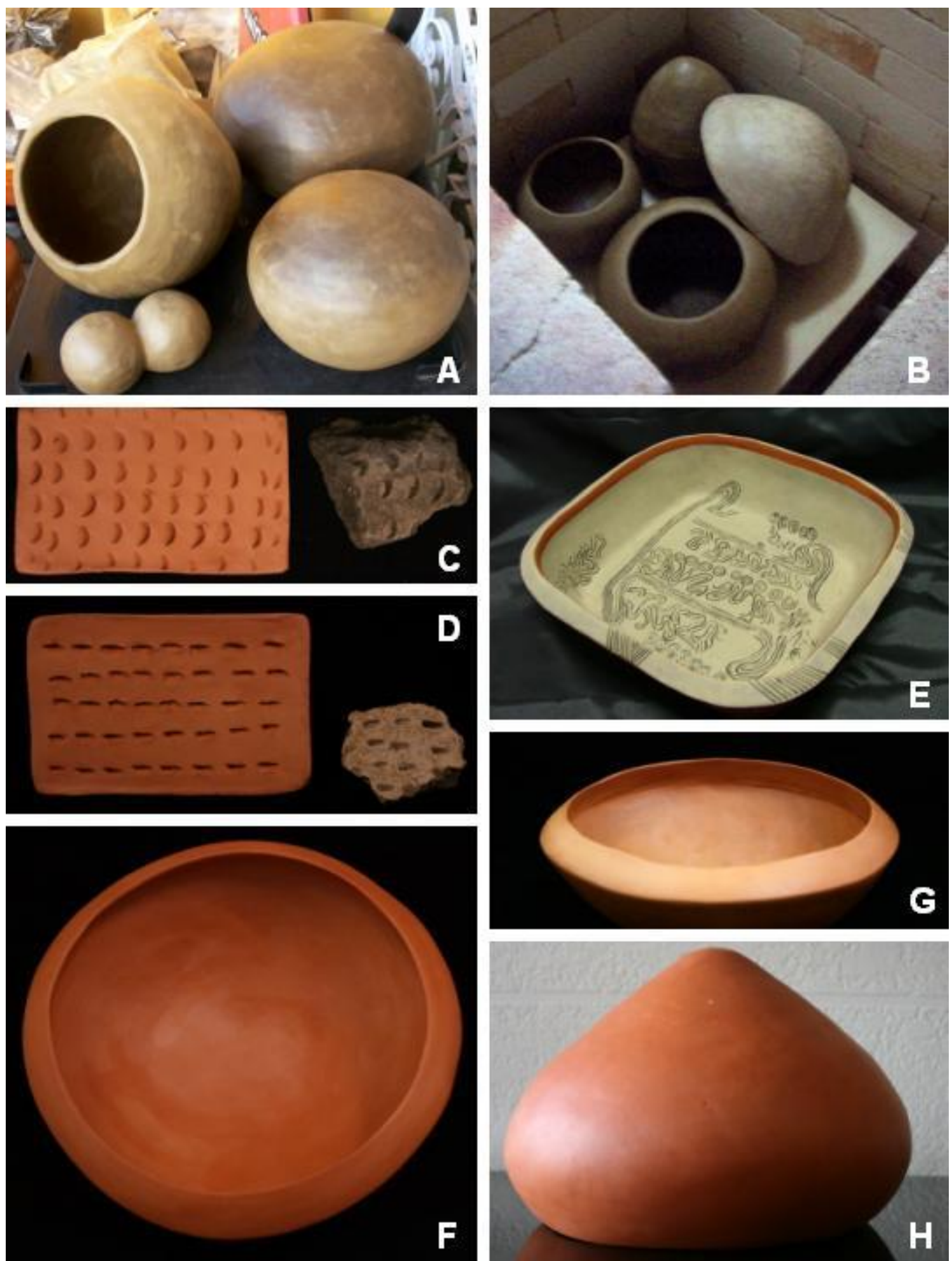

$\mathbf{F}$

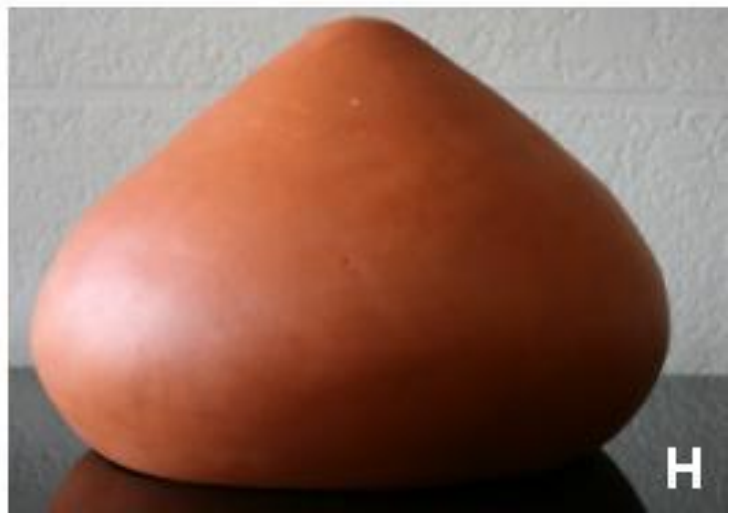

Figura 3.7 - Processo de secagem e queima, peças já queimadas: A - secagem das peças, B - peças no forno antes da queima, C e D - placas com exemplos de decoração antes depois da queima, E réplica de um prato Tupi que se encontra no acervo do Museu de História Natural da UFMG, F e G - réplica de prato tupi, $\mathrm{H}$ - réplica de urna funerária Aratu. 

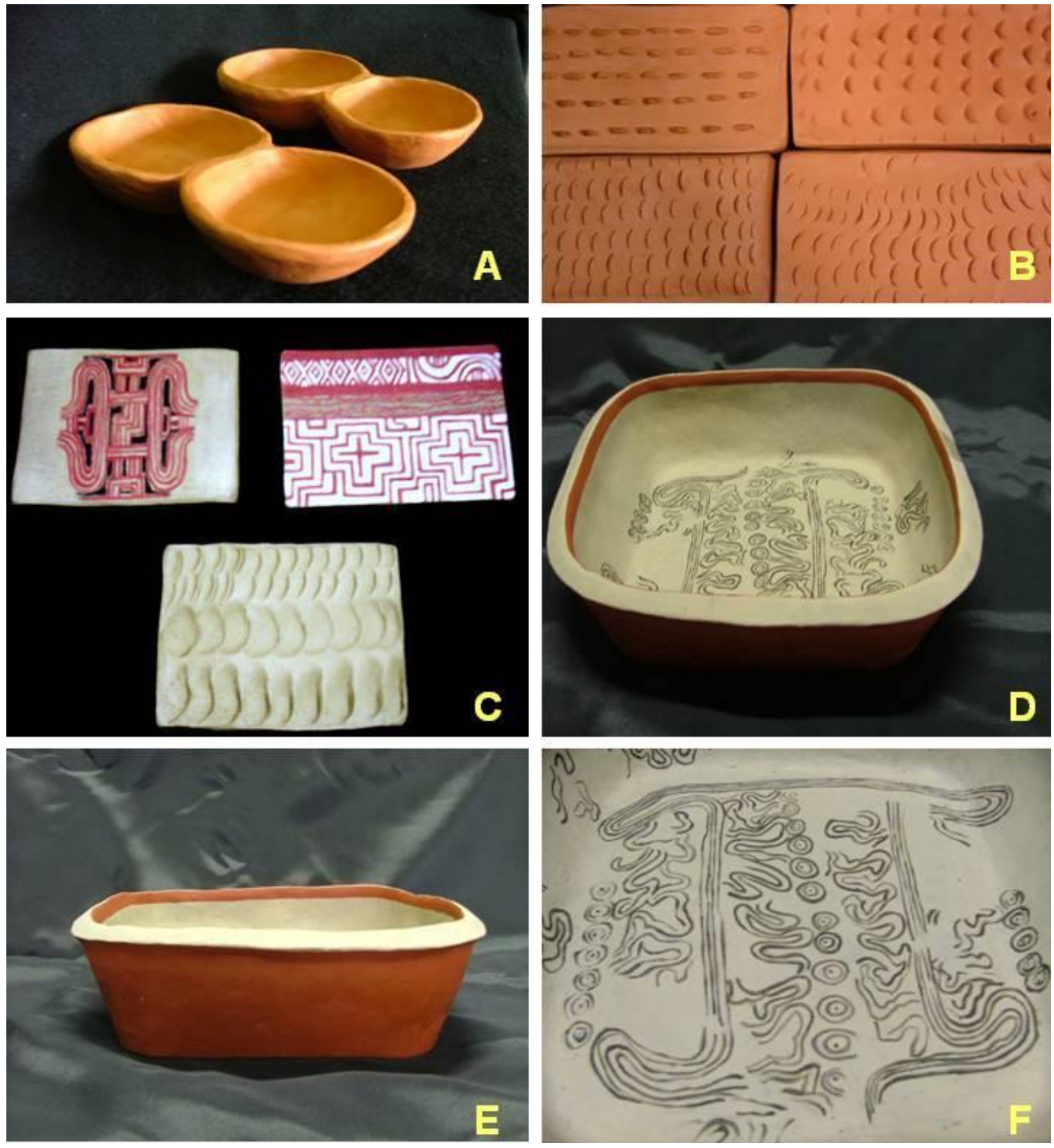

Figura 3.8 - Réplicas e placas com decoração: A - Formas duplas Aratu, B - Placas com decoração ungulada após a queima, C - Placas com decoração pintada antes da queima D, E e F - Réplica de um prato Tupi pintado que se encontra no acervo do Museu de História Natural da UFMG. 

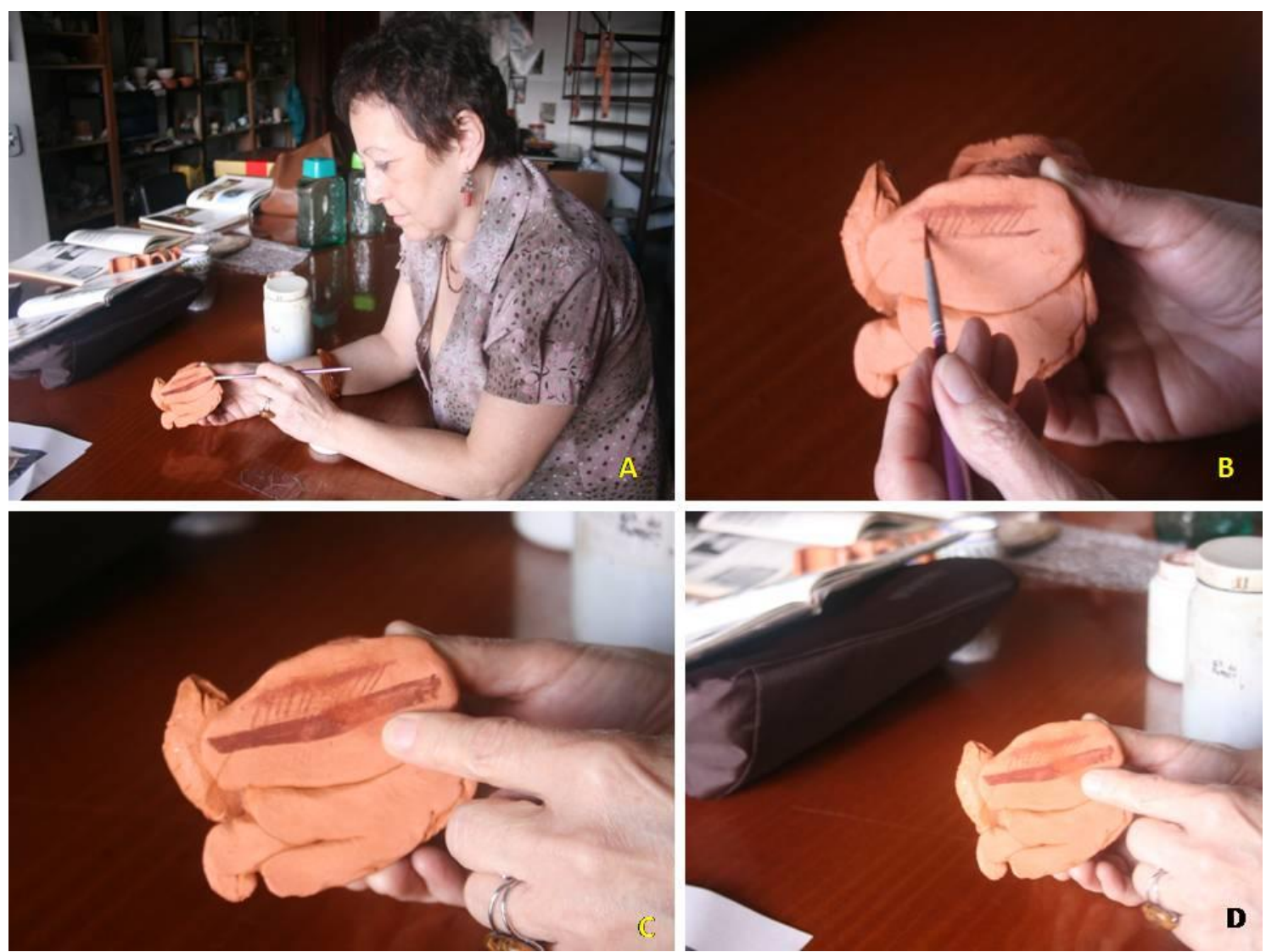

Figura 3.9 - Teste com pigmento. A - Ceramista Mayy Koffler; B, C e D - Experimentação com óxido de ferro.

\subsection{Resultados e discussão}

Com relação à argila selecionada, a sua cor em estado úmido é avermelhada e depois de queimada apresentou uma cor vermelho-acastanhado que tende a escurecer quando atingido o limite de cozedura (Chavarria, 1999). Devido à plasticidade da argila foi possível construir as peças de forma mais lenta e controlar melhor as etapas de produção, corrigindo erros antes que o barro estivesse totalmente seco.

Observou-se que as peças confeccionadas, uma vez respeitado o tempo de preparação da pasta, raramente estouraram ou racharam durante a secagem e queima. No entanto, as peças em que essa etapa de produção foi eliminada ou realizada de forma rápida, não obtiveram um bom resultado. Assim fica evidente que o trabalho com a cerâmica exige grande disponibilidade de tempo do artesão, pois se realizada de forma rápida compromete a dedicação de dias. 


\section{Técnica de confecção}

As maiorias das quebras paralelas ao rolete dos fragmentos do sítio Gramado ocorreram na linha de junção entre eles, tanto nas paredes, como entre paredes e bordas. Observou-se a presença de rachaduras em algumas bases, tornando evidente a técnica de confecção e a espessura dos cordéis (Figura 3.10).

A experimentação permitiu confirmar que muitas rachaduras ocorrem porque durante a etapa de junção dos roletes não foi realizado um bom alisamento. No momento em que a argila perde água e se contrai, cria-se um espaço favorável a rachaduras entre um rolete e outro. Portanto, a etapa de alisamento deve ser demorada para obter sucesso na confecção de uma peça. Muitas vezes, levam-se dias para conseguir um bom resultado. Com isso, pode-se dizer que uma sociedade ceramista fez uma escolha em dedicar ou permitir que certos indivíduos investissem grande parte de seu tempo na produção de potes de cerâmica, sejam eles para uso utilitário ou cerimonial.

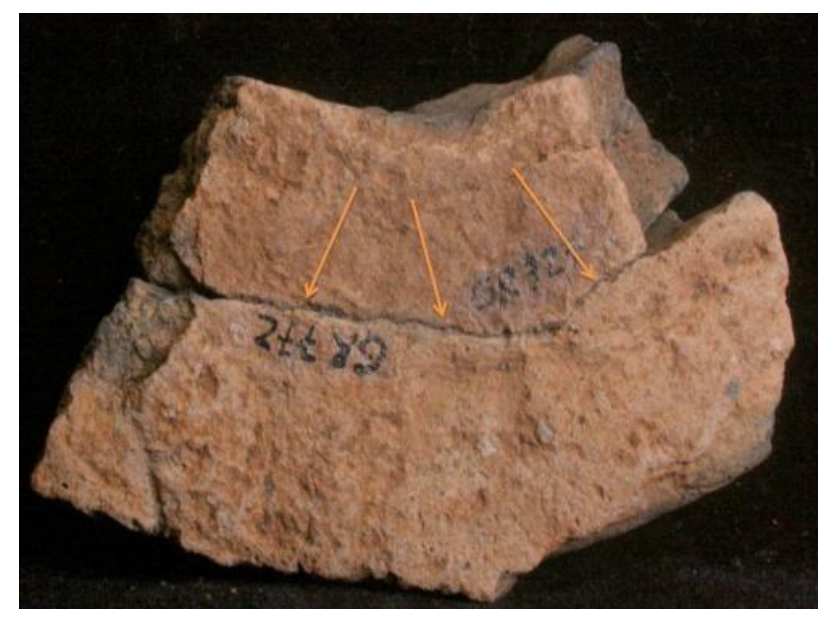

Figura 3.10 - Fragmento de base. Junção entre roletes.

Algumas peças da experimentação foram confeccionadas com a base modelada e as paredes acordeladas, com isso pôde-se constatar a importância da argila utilizada na base ter a mesma plasticidade dos roletes, caso contrário torna-se muito difícil uma integração sem marcas e, além disso, as chances de rachaduras no encontro base-parede são grandes.

Constatou-se que a confecção de um rolete perfeito exige muita habilidade do artesão, pois é necessário um bom controle de intensidade de força nas mãos para que o rolete se apresente com a mesma espessura por todo comprimento. As cerâmicas do sítio Gramado 
apresentaram poucos desníveis nas paredes, evidenciando tratar-se de um grupo experiente com a técnica do acordelamento.

Conforme a habilidade do artesão um único rolete pode dar três ou quatro voltas na borda do pote de uma só vez, porém, de vez em quando, torna-se necessário deixar que a peça endureça ao ir aumentando de tamanho para que o peso do barro não a derrube (Mattison, 2004). Com isso, uma peça grande não pode ser construída em um dia, mesmo que o oleiro seja experiente. Desta forma, pode-se levantar hipótese sobre os ceramistas do sítio Gramado no que diz respeito à posição do artesão dentro do grupo: uma vez que se levam dias para a construção de uma peça e essas são utilizadas no cotidiano das pessoas, a prática ceramista tem um impacto social, pois o oleiro que dedica seu tempo com a produção de potes deixou de realizar outras atividades pertinentes a vida em sociedade como, por exemplo, caçar, cozinhar ou cuidar dos filhos.

\section{Decoração plástica}

Foram experimentados dois tipos de decoração plástica: corrugada e ungulada. Para decoração corrugada, constatou-se que a união dos roletes com o dedo em movimentos de cima para baixo cria esse tipo de efeito decorativo (figura 3.11-A). Ao mesmo tempo, observou-se um tipo chamado de decoração corrugado "espatulado" que não pode ter sido realizada com o dedo e sim com um instrumento parecido com uma espátula (Moraes, 2007) (figura 3.11- B). 

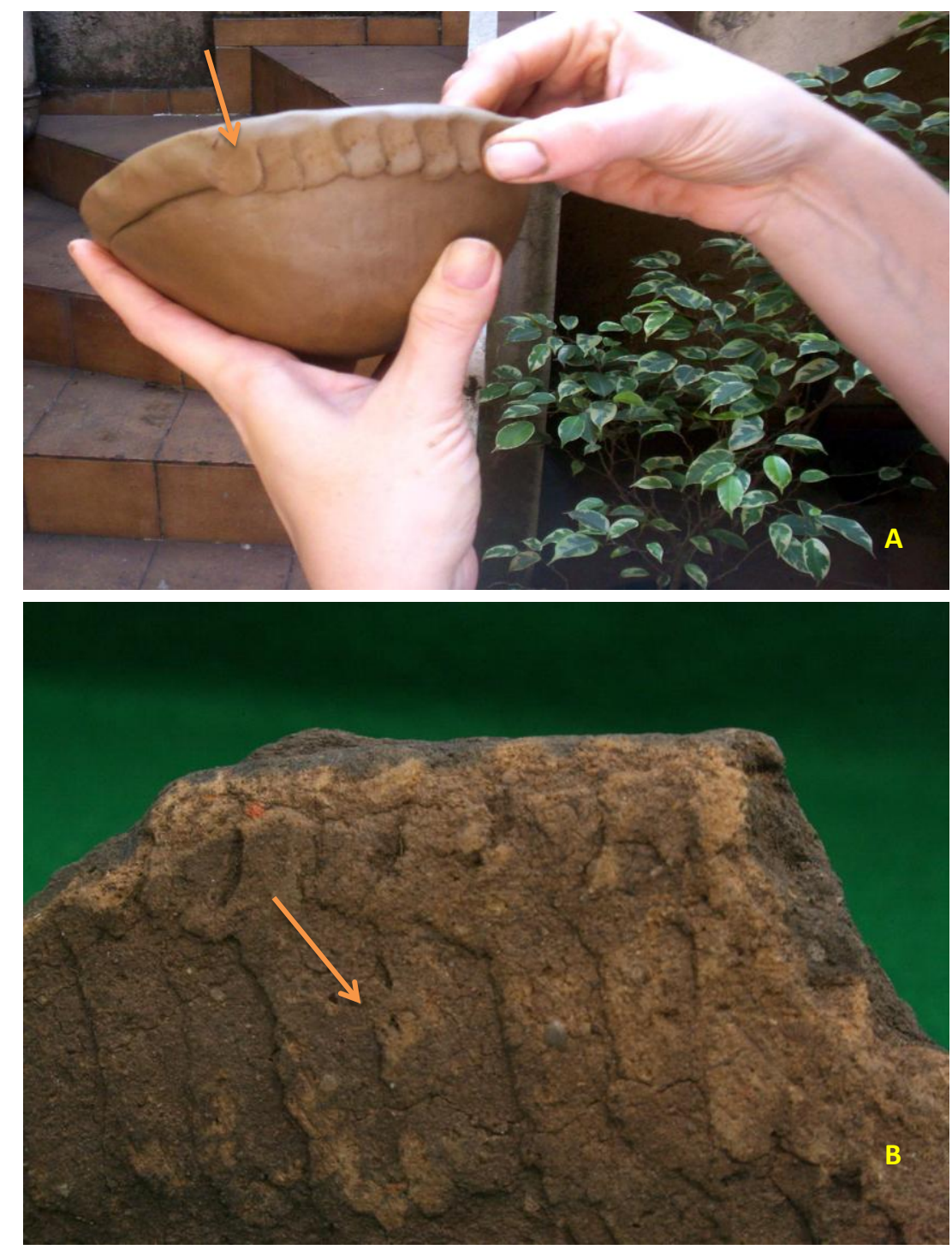

Figura 3.11 - Exemplos de decoração plástica. A - Corrugado a partir da junção dos roletes. B Corrugado espatulado.

Para a decoração ungulada foi possível perceber que a utilização de materiais diversos como o bambu e ripas de madeira permitiu maior domínio da técnica e, com isso, facilitou a construção rítmica de linhas decorativas. O uso da unha exigiu maior habilidade do artesão para dominar a intensidade de força e criar uma decoração simétrica.

\section{Decoração pintada (engobo)}

Os pigmentos aplicados quando a argila estava em "ponto de couro" antes da queima mostraram-se muito resistentes, comparados com aqueles que a pintura foi realizada após, ou seja, o pigmento adquiriu maior aderência quando aplicado antes da cozedura. Com isso, contatou-se que para aplicação do engobo a superfície da peça deve estar no ponto que seja 
possível mexer no pote sem que ele perca a forma, mas ao mesmo tempo deve ter a umidade suficiente para poder incorporar o engobo em sua parede.

Verificou-se que o engobo aplicado na peça já seca tende a descascar. No entanto, as peças muito úmidas se quebrarão ao absorver a água do engobo.

A experimentação demonstrou que a pintura encontrada nos fragmentos do sítio Gramado foi realizada antes da queima e que o artesão tinha conhecimento sobre o ponto certo para a aplicação do pigmento.

\section{Brunidura}

O brunido adquire uma função importante na decoração de um pote, principalmente quando aplicado por cima de engobo, pois permite criar zonas contrastantes de brilho, conforme se verifica nas figura 3.7 - B-D e 3.7-A (Casson, 1991). As experimentações com polimento realizadas com seixos permitiram observar que esta etapa da confecção exigiu muito trabalho e tempo do artesão. Para brunir uma peça grande, podem-se levar dias trabalho. Portanto, um pote com engobo e brunidura leva muito mais tempo para ser confeccionado, comparado com os potes de parede lisa ou com decoração plástica. Desta forma, pode-se inferir sobre as importâncias e utilizações diversas dos vasilhames dentro do grupo que as produziu conforme as intencionalidades de tratamento e acabamento de uma peça cerâmica.

\section{Secagem}

O tempo e a velocidade de secagem são primordiais para que a peça não rache durante este processo. As peças expostas ao sol direto para adiantar a secagem sofreram rachaduras graças à perda de água rápida. $\mathrm{O}$ tempo médio de secagem de uma peça variou entre 2 a 4 dias, dependendo da quantidade de água presente na argila e da temperatura ambiente. Por esse motivo, evitou-se adicionar água durante a confecção de uma peça, assim diminuiu-se o risco de rachaduras e o tempo de secagem.

\section{Queima}

$\mathrm{Na}$ etapa de queima utilizaram-se métodos modernos, como o do forno a gás. A queima ocorreu de forma gradativa e atingiu uma temperatura de $800{ }^{\circ} \mathrm{C}$. Com esta fase da pesquisa e mesmo sem utilizar um forno a céu aberto, pôde-se constatar que as peças que, em algum momento da etapa de produção, não foram bem feitas, quebraram ou racharam. As falhas podem 
ocorrer, tanto durante a preparação da argila (com a não eliminação das bolhas de ar), como pela má união dos roletes ou secagem da peça, pela secagem acelerada ou exposição ao sol.

Foi realizada uma queima de fragmento arqueológico do sítio Gramado (figura 3.12) por sete horas, em forno moderno e em temperatura de $980^{\circ} \mathrm{C}$. A cerâmica original possuía sinais de carbonização na região medular indicando que não houve oxigênio necessário para oxidar todo o carbono presente na argila e queimar bem todo o corpo cerâmico. Quando o fragmento sofreu uma segunda queima em forno a gás, perdeu a parte medular, indicando que com maior disponibilidade de ar no forno, temperatura adequada e tempo longo, essa parte não oxidada, pode ser completamente queimada.

Esse experimento sugere que a cerâmica original não teve oxigênio disponível em quantidade adequada para a queima, o que não significa necessariamente que era uma cerâmica mal cozida.

Já a observação da textura, porosidade, dureza, compactação, essas características físicas sim, sugerem que a cerâmica sofreu uma queima rápida, não permitindo que a temperatura queimasse uniformemente a peça. Com isso, o fragmento apresenta-se cozido nas partes externas, porém cru na região medular.

A cor da cerâmica não é necessariamente um indicador de mal cozimento. Simplesmente é a indicação de pouco oxigênio o que, muitas vezes coincide com uma queima incompleta, por ter sido realizada com grande quantidade de madeira e atmosfera redutora no local onde se inseria a cerâmica.

\section{Material educativo}

Os kits de réplicas de cerâmica arqueológica foram utilizados como material educativo em museus e eventos, entre eles: Museu Dona Beja de Araxá (Minas Gerais), Museu de História da Costa do Sauípe (Bahia) e Feira do Folclore de Olímpia (São Paulo) (Figura 3.13). As réplicas serviram para que os alunos e público geral das exposições pudessem tocar nas peças e entender como elas foram confeccionadas, além disso, serviram também como material de apoio para aulas e palestras. 


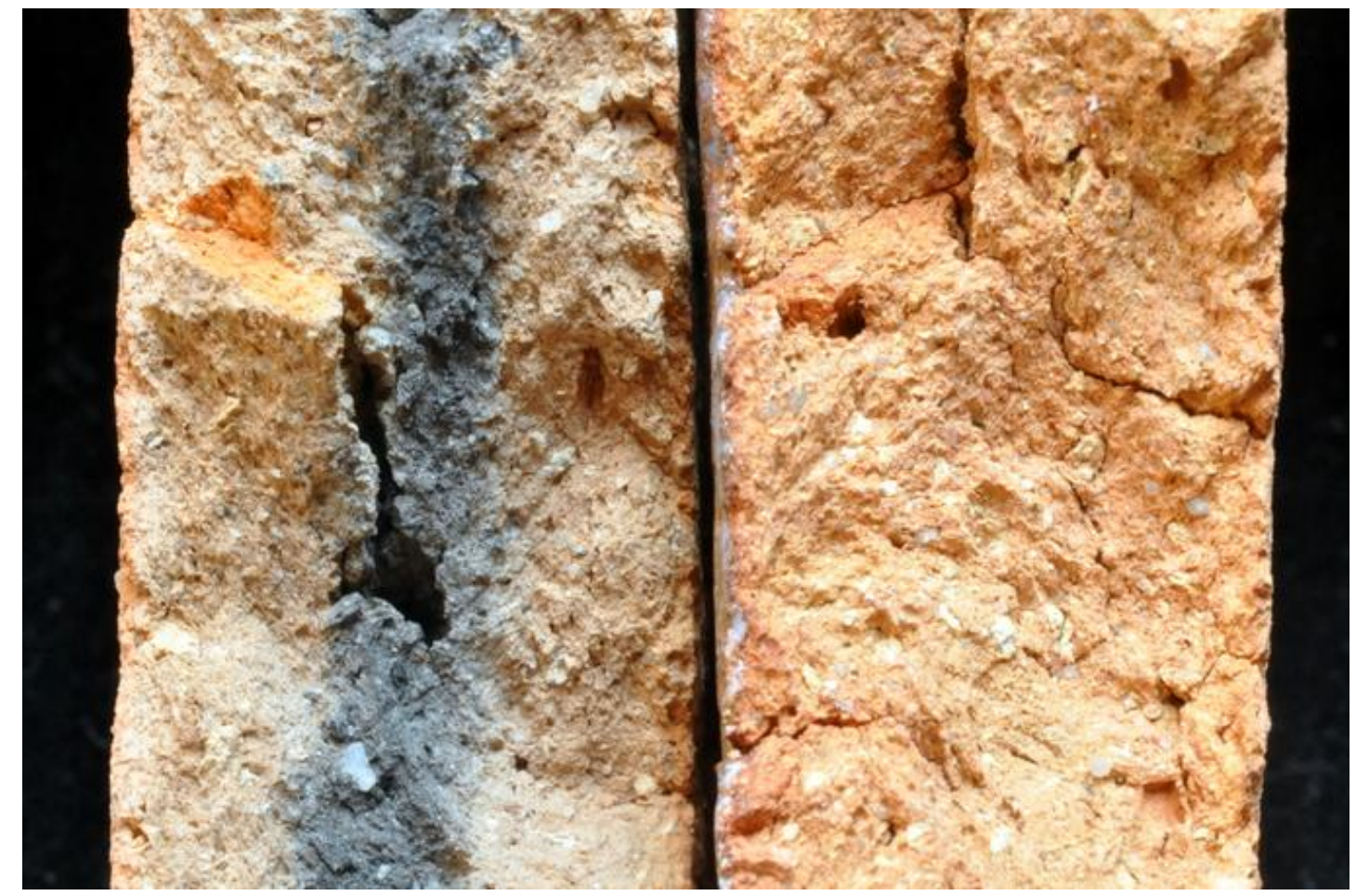

Figura 3.12 - Vista do corte de fragmento. Um mesmo fragmento de cerâmica, porém a da esquerda com a queima original e a da direita com queima recente em forno a gás com temperatura de 980 graus.

A confecção das réplicas permitiu observar a complexidade da construção de peças cerâmicas inteiras, tanto no que diz respeito ao tempo necessário para realização, acabamento, secagem e queima como lidar com o resultado obtido após a cozedura.

\subsection{Conclusão}

A análise sobre as cerâmicas arqueológicas do sítio Gramado esclareceu que: grande parte do material não teve bom tratamento de superfície, o que é evidenciado pelas quebras na união dos roletes; os tipos decorativos ungulados foram confeccionados com materiais diversos (fragmentos de bambu, ripas de madeira) que permitiram maior domínio da intensidade de força aplicada, à parte se comparado ao uso da mão; a maior parte das decorações corrugadas foi confeccionada com a mão, exceto aquelas com decoração espatulada; os pigmentos aplicados antes da queima (engobo) são permanentes, ao contrário dos pigmentos aplicados após a queima; as peças em que não foram respeitados os tempos adequados de preparação, secagem e queima, sofreram rachaduras e quebras durante o processo; os testes de queima apontaram que os fragmentos arqueológicos do sítio Gramado foram queimados em uma atmosfera redutora, além disso, sofreram uma queima rápida e em baixa temperatura, por isso tem uma textura friável, porosidade alta e baixa resistência. 

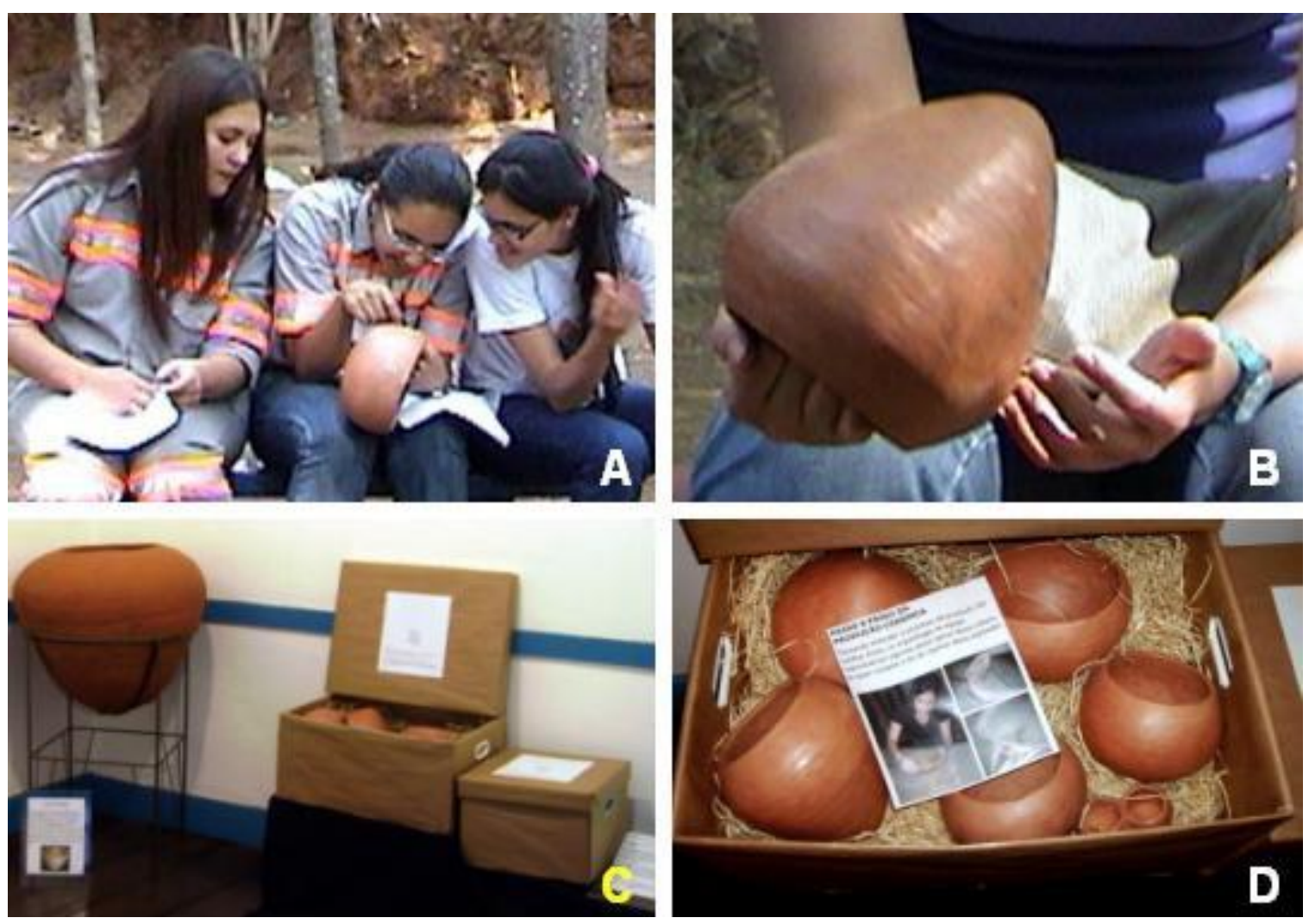

Figura 3.13 - Kit de Réplicas utilizadas como material educativo no Museu Dona Beja - Araxá - Minas Gerais. A - Alunos observando cerâmica, B - Réplica reduzida de uma urna funerária. C - Réplicas de cerâmica arqueológica ao lado de uma urna original, D - Kit com replicas.

As pesquisas com experimentação permitiram postular algumas hipóteses sobre sociedade que as produziu. Primeiramente, é importante considerar que dominar a confecção de uma peça cerâmica compreende possuir conhecimento sobre uma técnica complexa e duradoura. Além disso, algumas etapas de confecção de um pote exigem muito tempo do artesão e, com isso, evidenciam a dedicação de dias ou meses para elaboração e produção de material cerâmico, o que denota o valor que esse trabalho exercia dentro do grupo. A presença de cerâmicas pintadas, brunidas e com bom acabamento ao mesmo tempo em que outras se apresentavam com um corrugado grosseiro ou com as marcas de rolete evidentes, indica funções e importâncias variadas atribuídas aos potes cerâmicos, bem como a divisão de objetos conforme seu valor na sociedade. 


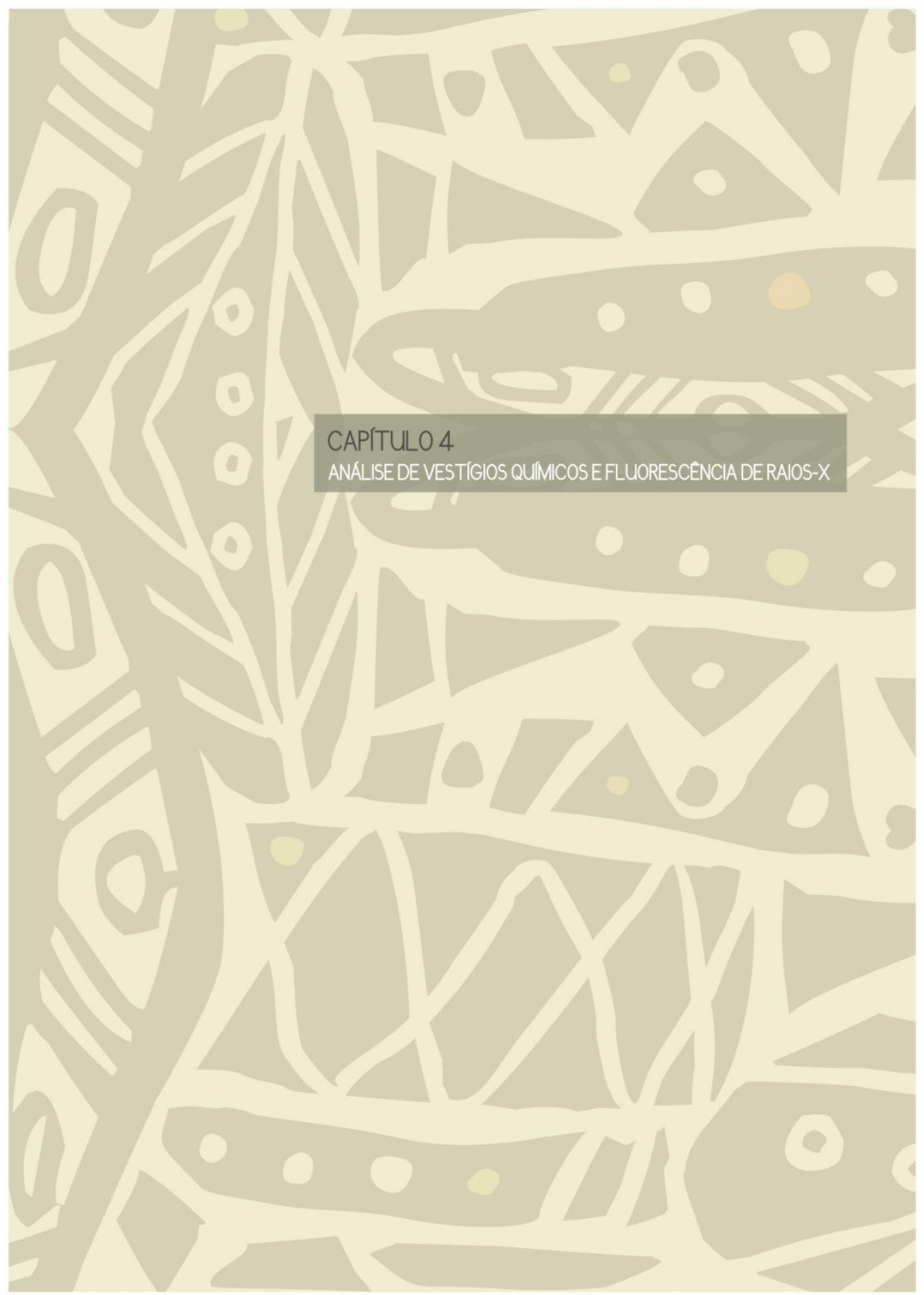




\section{SUMÁRIO}

\section{Capítulo 4 - Análise de vestígios de química e fluorescência de raios-X}

\subsection{Introdução}

4.2 Cerâmica do sítio Gramado

4.3 Materiais e Métodos

4.4 Resultados e Discussão

4.5 Conclusão

\section{Figuras}

4.1 Localização do sítio Gramado

4.2 Sítio Gramado

4.3 Peças cerâmicas para análises de vestígios na UNAM

4.4 Peças cerâmicas para análises de fluorescência de raios-X

4.5 Laboratório de Prospecção Arqueológica (UNAM)

4.6 Sistema portátil para análises de fluorescência de raios-X

4.7 Distribuição de freqüências relativas dos resíduos químicos no conjunto das cerâmicas

4.8 Distribuição da decoração plástica e fosfato

4.9 Distribuição de decoração pintada e fosfato

4.10 Distribuição de carbonatos e pH

4.11 Distribuição de carbonatos e ácidos graxos

4.12 Espectro de fluorescência de raios-X

4.13 Espectros de fluorescência de raios- $X$ de pasta cerâmica e pinturas

4.14 Espectros de fluorescência de raios- $X$ de pasta cerâmica e respectivas peças

\section{Tabelas:}

4.1 Características das cerâmicas e resultado dos testes de resíduos químicos

4.2 Classe de fragmentos e distribuição de fosfato 
4.3 Presença de resíduos químicos com valor 9 divididos por classe e tipo de decoração 4.4 Resultado de ocorrência de elementos químicos 


\subsection{Introdução}

Este capítulo apresenta análises químicas de vestígios de substâncias sobre fragmentos de cerâmica do sítio Gramado, município de Brotas - São Paulo, realizadas sob orientação do Prof. Agustin Ortiz no Laboratório de Prospecção Arqueológica da Universidad Nacional Autónoma de México em 2010, bem análises de pastas cerâmicas realizadas sob coordenação do Prof. Carlos Appoloni no Laboratório de Conservação do Museu de Arqueologia e Etnologia da Universidade de São Paulo (MAE-USP), utilizando o sistema do Laboratório de Física Nuclear Aplicada do Departamento de Física da Universidade Estadual de Londrina.

Como ambas as análises foram realizadas com técnicas não corriqueiras no MAE-USP e não se sabia, ao menos para as análises de vestígios químicos, como as amostras iriam se comportar usaram-se amostras relativamente pequenas. Por esse motivo, serão apresentadas hipóteses sobre o potencial de utilização dos vestígios químicos como evidências de utilização e função dos vasilhames cerâmicos e utilização conjunta com a análise da pasta cerâmica.

\section{Vestígios químicos}

Segundo Barba e Ortiz (1992), a metodologia de análise química utilizada complementa a proposta da abordagem da microarqueologia, porém com a diferença de que a primeira estuda os restos microscópicos visíveis e a análise química obtém informações de indicadores invisíveis.

O princípio da análise química em arqueologia baseia-se na idéia de que a maioria das atividades humanas, tais como comer, preparar alimentos e oferendas, produzem resíduos que ficam impregnados tanto no solo substrato, como nos materiais arqueológicos. Parte desses resíduos encontrados em forma de fluidos se fixam nos poros dos materiais e ao se aplicar análises químicas específicas, podem ser detectados muito tempo depois de quando foram usados (Barba e Lazos, 2000).

$\mathrm{O}$ uso da prova de fosfato na arqueologia deu-se no inicio do século $\mathrm{XX}$ e foi largamente utilizada em estudos sobre da terra em todo mundo. $\mathrm{O}$ marco inicial dessas abordagens deu-se com o agrônomo sueco Olaf Arrhenius (1926) que, trabalhando no cultivo da terra, observou a existência de alto índice de fosfato no solo e com isso descobriu tratar-se de antigo assentamento viking. Esse fato despertou o interesse de arqueólogos e geógrafos que perceberam a importância da análise de fosfato como forma de encontrar assentamentos humanos (Arrheunius, 1963; Mejía-Perez e Barba, 1988; Vinberg 1990). 
Segundo Cañabate e Viscaíno (1995), em meados dos anos 50 do século XX, Feigl (1988) desenvolveu um método de análise chamado spot-test, que consistia em colocar em prática resultados qualitativos oferecidos por diferenças de cor obtidas ao aplicar um conjunto de reativos sobre uma mostra. Depois de Feigl (1988), outros pesquisadores como: Eidt (1977), Bakkevig (1980), Prosch-Danielsen e Simonsen (1988) modificaram e aprimoram a técnica em vários países.

Vale ressaltar o trabalho realizado nos anos 70 do século XX pela Escuela Nacional de Antropologia y Politica e o Instituto de Investigaciones Antropológicas do México (UNAM) que, nesse período, começaram a utilizar as análises químicas incorporadas ao estudo de assentamentos da época pré-hispânica. $\mathrm{O}$ uso da análise química tem como ponto de partida no México os trabalhos de Manzanilla (Puebla) e Hirth (Morelos). Barba e Bello (1978) inovaram ao combinar a análise de fosfato com outras análises químicas, como: carbonatos, enxofre, o pH e cores nos sítios arqueológicos de Terremote (Distrito Federal) e no vale de Xochicalco (Canabate). Algumas linhas de pesquisa buscaram combinar o grau de enriquecimento químico do solo com as atividades humanas, para entender áreas de atividade, como locais relacionados ao consumo, armazenamento, descanso, descarte e ritual. Pode-se exemplificar essa abordagem com os trabalhos do conjunto residencial maia Cobá (Quintana Roo) de Barba e Tovalín(1987) ou Manzanilla e Barba (1990) bem como o conjunto Teotihuacano de Oztoyohualco (Teotihuacan) de Barba et. al. (1987) e Ortiz (1990). (Cañabate e Vizcaíno, 1995)

Já a identificação de vestígios químicos na cerâmica contribui para compreender o conteúdo e função do objeto, proporcionando resultados que podem avançar para além de uma definição tipológica ou um estudo físico-químico das pastas cerâmicas, contribuindo para entender questões relacionadas à dieta e a subsistência (Cañabate y Vizcaíno, 1995).

Segundo Cañabate e Viscaíno (1995), um dos primeiros trabalhos relevantes com o uso da analise química em cerâmica foi escrita por Von Stokarque evidenciou o uso de azeite de linhaça em um recipiente viking. Com isso advertiu sobre a importância do estudo dos restos cerâmicos antes da limpeza completa dos mesmos.

Condamin et al. (1976) publicaram trabalhos que buscaram a presença de ácidos graxos em cerâmicas arqueológicas, mais precisamente em uma ânfora romana. Para tanto, utilizou fragmentos da parte externa e interna da ânfora, além de amostras de terra do seu interior. (Cañabate e Vizcaíno, 1995).

No sítio costeiro de Kasteelberg, península de Vredenburg, África do Sul, Patrick et al., 1985) fizeram análises em uma porcentagem de fragmentos de cerâmica para entender a 
presença de uma substância marrom. A partir da cromatografia gasosa e estudando os ésteres metílicos dos ácidos graxos, constatou-se a presença de conteúdo de origem marinha nos recipientes e em conjunto com outras análises, concluiu-se que os recipientes de cerâmica eram utilizados para servir carne de animal marinho, provavelmente de foca (Cañabate e Vizcaíno, 1995).

Evershed et al. (1990), definiram uma nova metodologia de trabalho para estudar resíduos em recipientes cerâmicos provenientes do Vale de Nene, Northamptonshire, Reino Unido. A inovação deu-se principalmente na forma de extração da amostra e no processo de tratamento das mesmas, no qual se optou por trabalhar com os derivados silanizados dos ácidos graxos resultantes da reação com tetra-metil-silano. Com isso, percebeu-se que era possível estabelecer uma diferença qualitativa e quantitativa entre os lipídios do solo e os absorvidos pelo recipiente durante seu uso. Esse mesmo grupo também trabalhou com a variação de distribuição dos lipídios em diferentes partes do recipiente, identificando a variação de ocorrência. (Cañabate y Vizcaíno, 1995).

No Brasil há trabalho de Amenomori (2005) sobre a ocupação dos grupos pescadorescoletores pré-históricos no litoral norte de São Paulo, bem como os trabalhos de Hansel et al. (2008) sobre os lipídios em sedimentos arqueológicos no sítio arqueológico Rio do Meio, Ilha de Santa Catarina, SC.

\section{Fluorescência de Raios-X}

Desde a década de 60 do século XX, a arqueometria tem sido utilizada de forma ampla nos estudos com objetos de arte e arqueologia no mundo, porém, no Brasil, somente nos anos 90 iniciaram-se estudos mais aprofundados na área. Destacam-se os trabalhos do Laboratório de Física Nuclear Aplicada de Londrina, com tomografia e fluorescência de raios-X por dispersão em energia (EDXRF), cuja primeira pesquisa consistiu na aplicação da técnica com fragmentos cerâmicos arqueológicos da coleção do Museu Histórico da Universidade Estadual de Londrina (Appoloni, 1997).

A utilização de técnicas de química analítica usando princípios físicos da matéria nos estudos de objetos de arte e conservação de objetos arqueológicos compreende uma ampla gama de possibilidades que vão desde as técnicas termo-eletro-acústicas até as atômicas e nucleares. Essas técnicas podem ser destrutivas, semi-destrutivas ou mesmo não destrutivas e são utilizadas 
para identificar tipos de materiais, técnicas, bem como a conservação preventiva de objetos de arte (Appoloni, 2008).

Alguns museus do mundo já vincularam laboratórios de Física aos seus espaços de pesquisa. É possível elencar como exemplos de experiências exitosas o Museu do Louvre de Paris e o Metropolitan Museum of Art de Nova York (Appoloni, 2008).

$\mathrm{Na}$ arqueologia, a Física pode contribuir para a compreensão do ciclo de vida dos objetos cerâmicos, auxiliando na reconstrução da trajetória do artefato, a partir de escolhas tecnológicas feitas pelo grupo estudado. Os métodos físicos, como: fluorescência de raios-X por dispersão em energia (EDXRF) e transmissão de raios gama $(\gamma)$ permite identificar elementos químicos presentes numa amostra cerâmica, além de evidenciar peculiaridades de composição da pasta (Silva et al., 2005). A EDXRF é uma técnica não-destrutiva e multielementar que, atualmente, com o desenvolvimento de detectores não-criogênicos com alta resolução em energia eletrônica nuclear compactada, sistemas portáteis possibilitaram realizar as medidas in situ (Appoloni et al., 2001, 2007a, b,; Appoloni e Parreira, 2007).

\section{2- O sítio Gramado, Brotas - São Paulo.}

O sítio Gramado é um sítio cerâmico, associado à tradição Tupiguarani, onde se coletaram cerca de cinco mil fragmentos cerâmicos. Dentre esses materiais, havia uma urna cerâmica fragmentada com decoração ungulada e com a presença de material esqueletal em seu interior. O sítio situa-se no município de Brotas, que está localizado na porção sudeste do Brasil, região central do Estado de São Paulo e a noroeste da capital figura 4.1.

$\mathrm{Na}$ figura 4.2 observam-se dois momentos da etapa de campo do sítio Gramado. A figura 4.2 - A e B corresponde ao ano de 1994 e apresenta a preparação do terreno, a divisão do espaço por quadras e a confecção de sondagens, enquanto a figura 4.2 - C e D mostra o sítio em 2009 com a plantação de cana de açúcar e material cerâmico na superfície. 


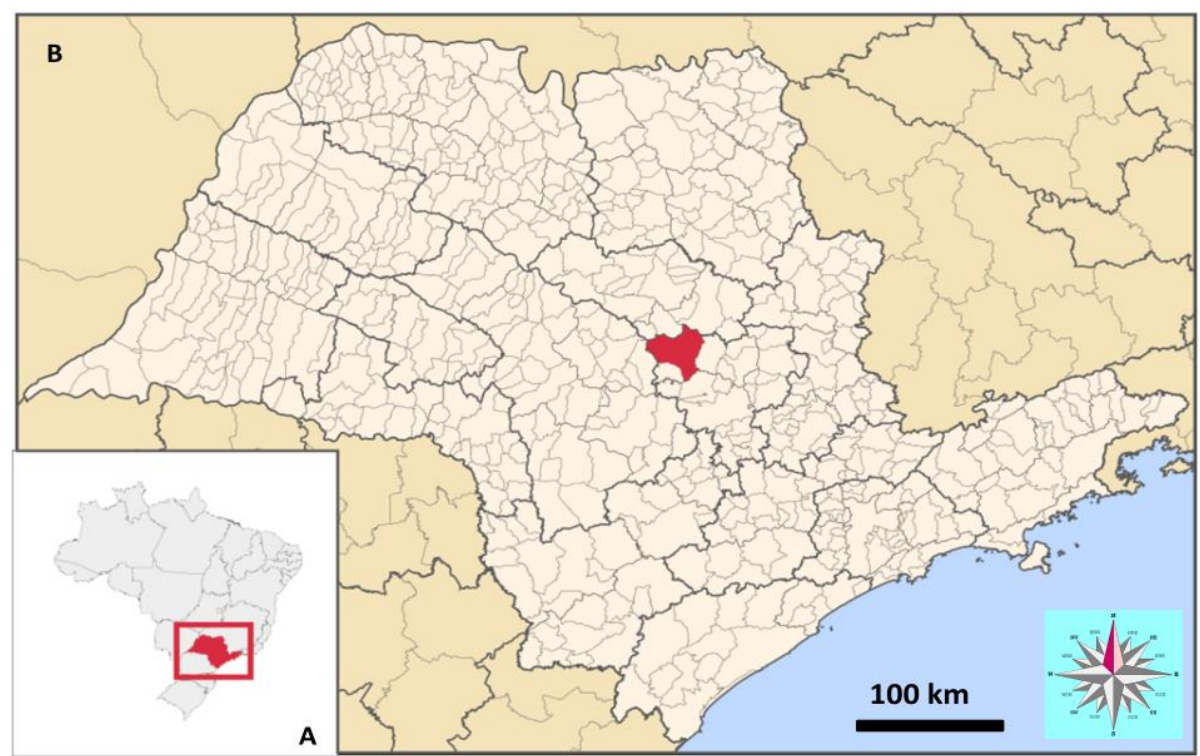

Figura 4.1 - Localização do sítio Gramado. A - Localização do Estado de São Paulo no Brasil. B Município de Brotas no Estado de São Paulo
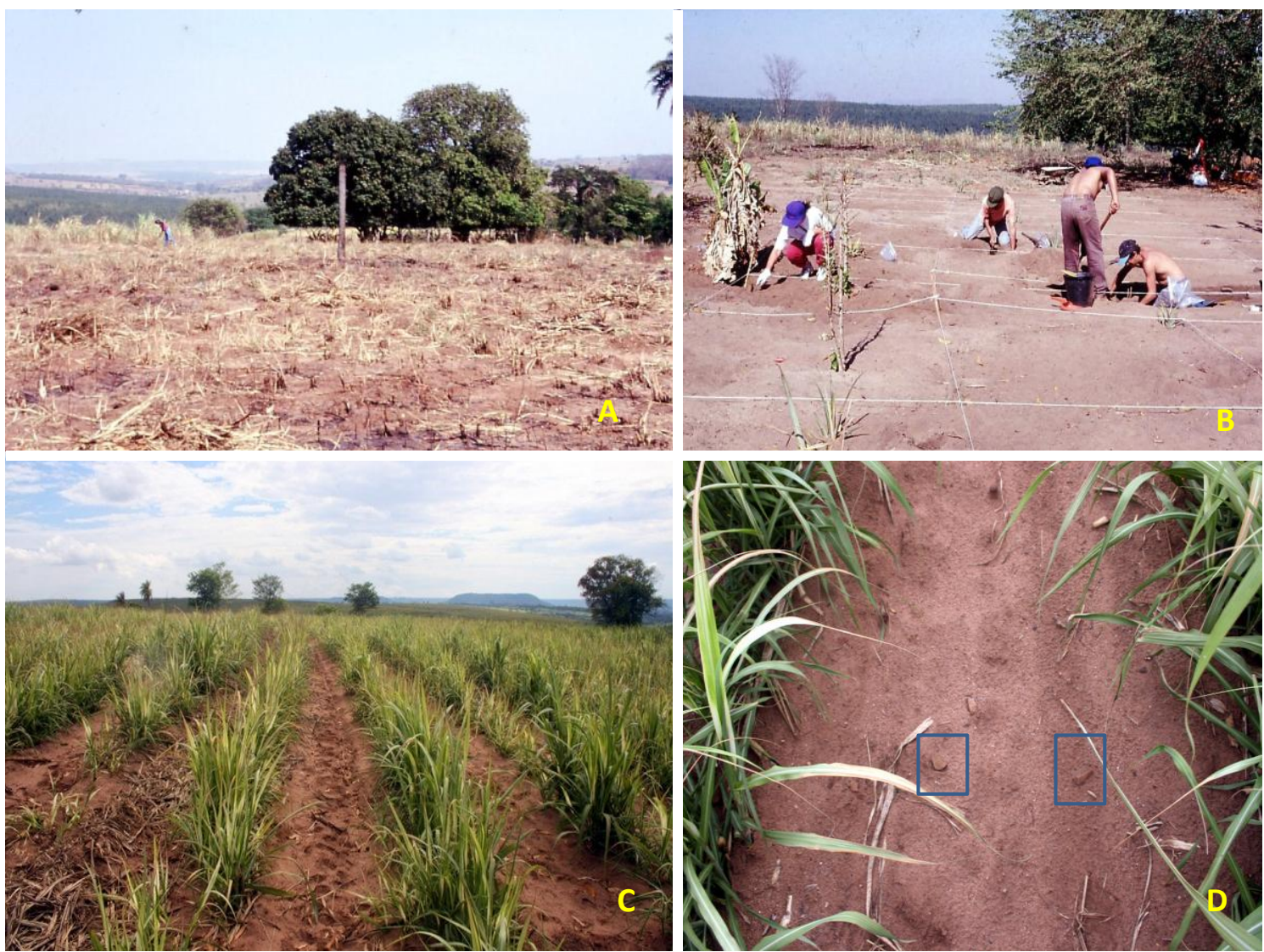

Figura 4.2 - Sítio Gramado 1994 e 2009. A e B - Vista geral e divisão das quadras 1994, C e D - Vista geral e cerâmica na superfície 2009. 
O relevo regional constitui-se de formação de "cuestas balsaticas" como manancial hídrico, importante Rio Jacaré Pepira, afluente do Rio Tietê e um dos poucos rios não poluídos do Estado de São Paulo, pertencente à bacia do Rio Paraná, ocupando uma área de $2.612 \mathrm{~m} 2$.

O nome do rio Jacaré Pepira è de origem Tupi-Guarani. Segundo Bueno (1993), a palavra Jacaré é de origem tupi e a grafia da palavra era Yacaré, cujo significado è "aquele que olha de lado, aquele que è torto". O termo "ya-carépepira" significa o jacaré esfolado ou descascado (Bueno, 1993).

A datação do sítio foi feita por termoluminescência no laboratório Sonia Hatsue Tatumi, na Faculdade de Tecnologia do Estado de São Paulo - Centro Paula Souza. As datações obtidas foram:

- $190 \pm 20$ anos BP (FATEC, número LVD 592) apresentada na tese de doutorado CaçadoresColetores pré-históricos: estudo geoarqueológico da bacia do ribeirão Queimador (vale médio do rio Tietê) por Afonso (2005).

- $400 \pm 9$ (2009) apresentado no XV Congresso de Arqueologia Brasileira.

\subsection{Materiais e Métodos}

\section{Materiais para análise química}

Foram feitas provas químicas em 15 mostras de cerâmica do sítio Gramado para identificar as concentrações de carbonatos, fosfatos, valor de $\mathrm{pH}$, resíduos protéicos e resíduos graxos presentes na cerâmica. Do total de cerâmicas, 12 foram coletadas em 1994 e haviam sido lavadas com água e 03 foram coletadas em 2009 e não haviam sido lavadas.

Das quinze mostras selecionadas, doze foram coletadas em sub-superfìcie durante trabalho de campo (1994) e três foram coletas em superfície durante visita técnica ao sítio (2009). Portanto, a cerâmica utilizada na análise química é proveniente de duas etapas de coleta. $\mathrm{Na}$ primeira etapa, em 1994, foram realizadas sondagens e trincheiras a partir da distribuição dos vestígios cerâmicos superficiais. A coleta variou entre material de superfície até a oitenta $\mathrm{cm}$ de profundidade, além disso, também se realizou coleta seletiva de bordas e fragmentos com decoração. A etapa de 2009 teve como finalidade verificar a situação recente do sítio Gramado e entrevistar os moradores da Fazenda Aparecida do Gramado, depois de quinze anos da pesquisa de campo inicial. Foi realizada coleta pontual de pouco material cerâmico de superfície, no 
entanto observou-se muita cerâmica em superfície entre as fileiras de plantação de cana de açúcar, ainda em fase jovem de crescimento. O solo em ambas as etapas estava remexido por maquinário agrícola, o que contribuiu para evidenciar o material cerâmico em superfície.

O critério de seleção das amostras teve como finalidade de abranger uma diversidade de formas e decorações (figura 4.3), sem privilegiar a localização dos fragmentos dentro do sítio. Dessa forma, não foi o objetivo criar um mapa com áreas de concentração e ausência de cada indicador químico, mas sim evidenciar características que possam fornecer informações importantes sobre a função de cada fragmento.

\section{Materiais para análise de fluorescência de raios-X}

Foram selecionados oito fragmentos cerâmicos do sítio Gramado coletados em sub-superfície na etapa de campo de 1994. O critério de escolha consistiu na seleção de fragmentos com pintura, mas de partes e potes diferentes, como: base, borda e parede, além de fragmentos com decoração plástica, porém, a escolha não enfatizou a localização exata do fragmento no sítio. Um segmento do fragmento de base GR-1949 passou pela análise de vestígios químicos e, também pela análise física, possibilitando uma análise comparativa dos resultados das duas técnicas. Na Figura 4.4 são apresentados os materiais estudados por fluorescência de raios-X. 


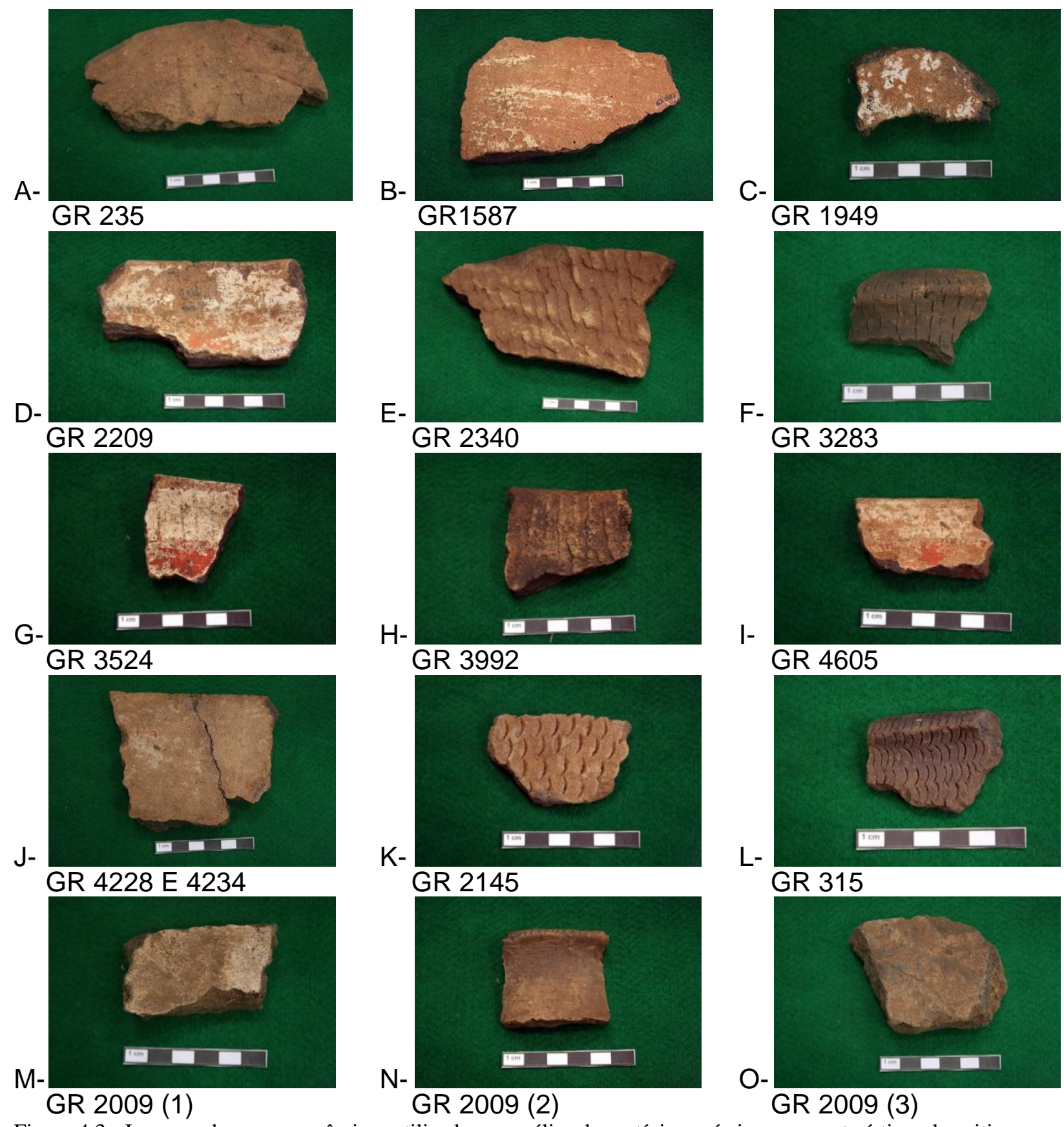

Figura 4.3 - Imagens das peças cerâmicas utilizadas na análise de vestígios químicos e características descritivas.

As cerâmicas selecionadas correspondem a bases e bordas com e sem decoração, paredes com decoração plástica e pintada, paredes lisas e de espessuras diversas. 
A

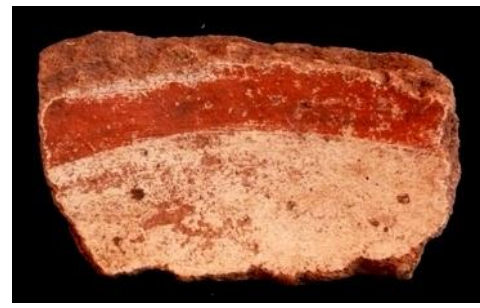

GR 1406

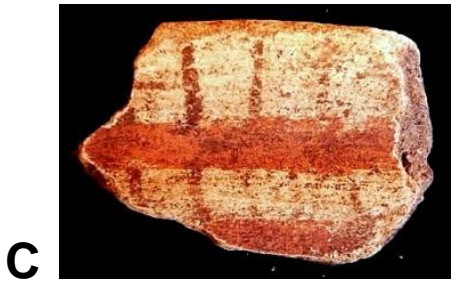

GR 238

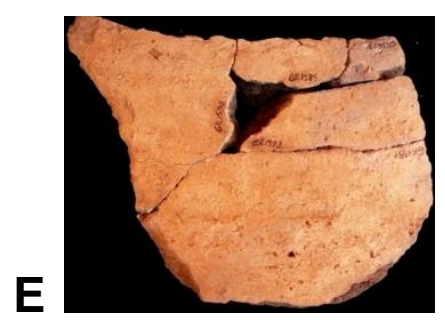

GR1583

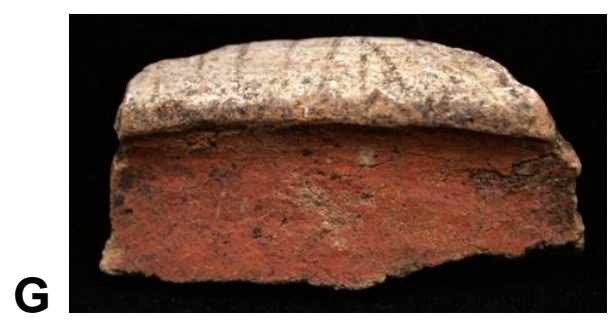

GR4663
B

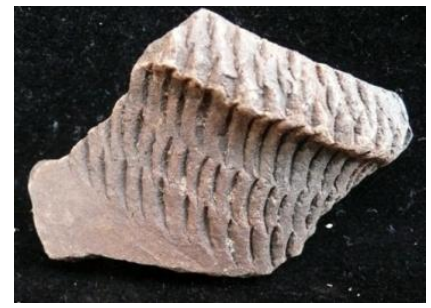

GR 270

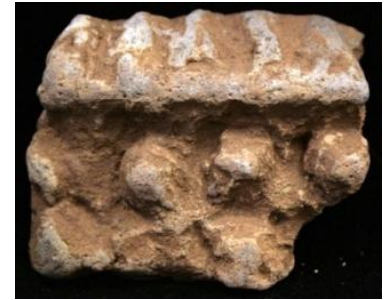

GR 2316

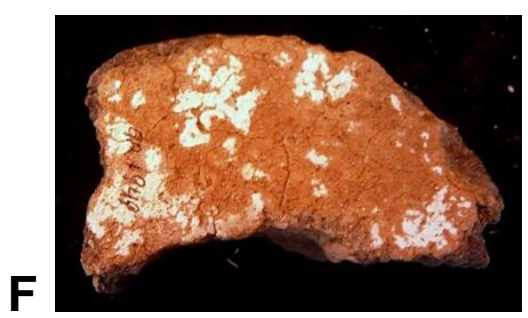

GR1949

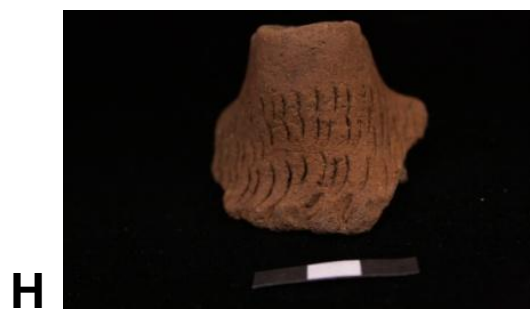

GR3542

Figura 4.4 - Fragmentos para análise de fluorescência de raios-X. Peças analisadas e fonte espectrógrafo de raios-X usados nas leituras arqueométricas.

\section{Método de análise química de vestígios}

A análise de vestígios é ilustrada na figura 4.5.
a) Fosfato

Provêm de tecidos ósseos, fezes, urina e restos de carne e pele. Uma característica dos fosfatos é a sua estabilidade química, podendo permanecer por muito tempo no sítio onde foram depositados (Barba et al.1991). Esta prova é considerada semiquantitativa foi desenvolvida inicialmente por Eidt (1977). 
b) Ácidos graxos

Devido à caracterização da matriz argilosa (cerâmica), os lipídeos ficam impregnados na argila, permanecendo protegidos de interferências externas (Heron e Evershed. 1993).

Esta prova consiste em analisar a quantidade de ácidos graxos de uma amostra, a partir da presença e permanência de bolhas.

O aparecimento de ácidos graxos reflete substâncias como óleos, gordura ou resinas, que estão presentes em zonas de preparação de alimentos, em banheiros ou espaços rituais (Barba et al., 1991).

c) Carbonatos

Os carbonatos são sais inorgânicos e o mais comum é o calcário ou carbonato de cálcio. Com essa prova pode-se evidenciar a presença de sedimentos e "estucados" (gesso maia), derivados marinhos de concha de animais e concreções de cavernas.

Baseia-se na reação efervescente com ácido clorídrico, que libera bolhas de hidrogênio. Estabelece-se uma escala de 0 a 5 para diferenciar os níveis de intensidade, ou seja, a efervescência é indicativa da quantidade de carbono na amostra.

d) Resíduos protéicos

É o produto da decomposição de compostos que tiveram proteína e indicam a presença de produtos animais ou vegetais, como: carne, sangue ou que refletem a preparação de alimentos e/ou rituais (oferendas, sacrifícios e auto-sacrifício).

Essa prova consiste em detectar os resíduos de proteína quando reagem com um agente alcalino, liberando amoníaco na forma de gás. A amônia é detectada com o papel indicador universal de $\mathrm{pH}$. Observa-se um valor de escala de 0 -14, porém somente a partir do valor oito considera-se presença de resíduos proteicos.

e) Potencial de Hidrogênio - $\mathrm{pH}$

Pode-se identificar a acidez e a alcalinidade. Para medir essas propriedades criou-se uma escala que se baseia na concentração de íons hidrônio em uma solução (pH=-log [H]). 
Uma das aplicações do pH é a identificação de cinzas no contexto arqueológico, o que significa localizar os lugares em que se realizou combustão. Na cerâmica é possível identificar se essa foi exposta ao fogo ou não depois da queima (Barba el al., 1991).
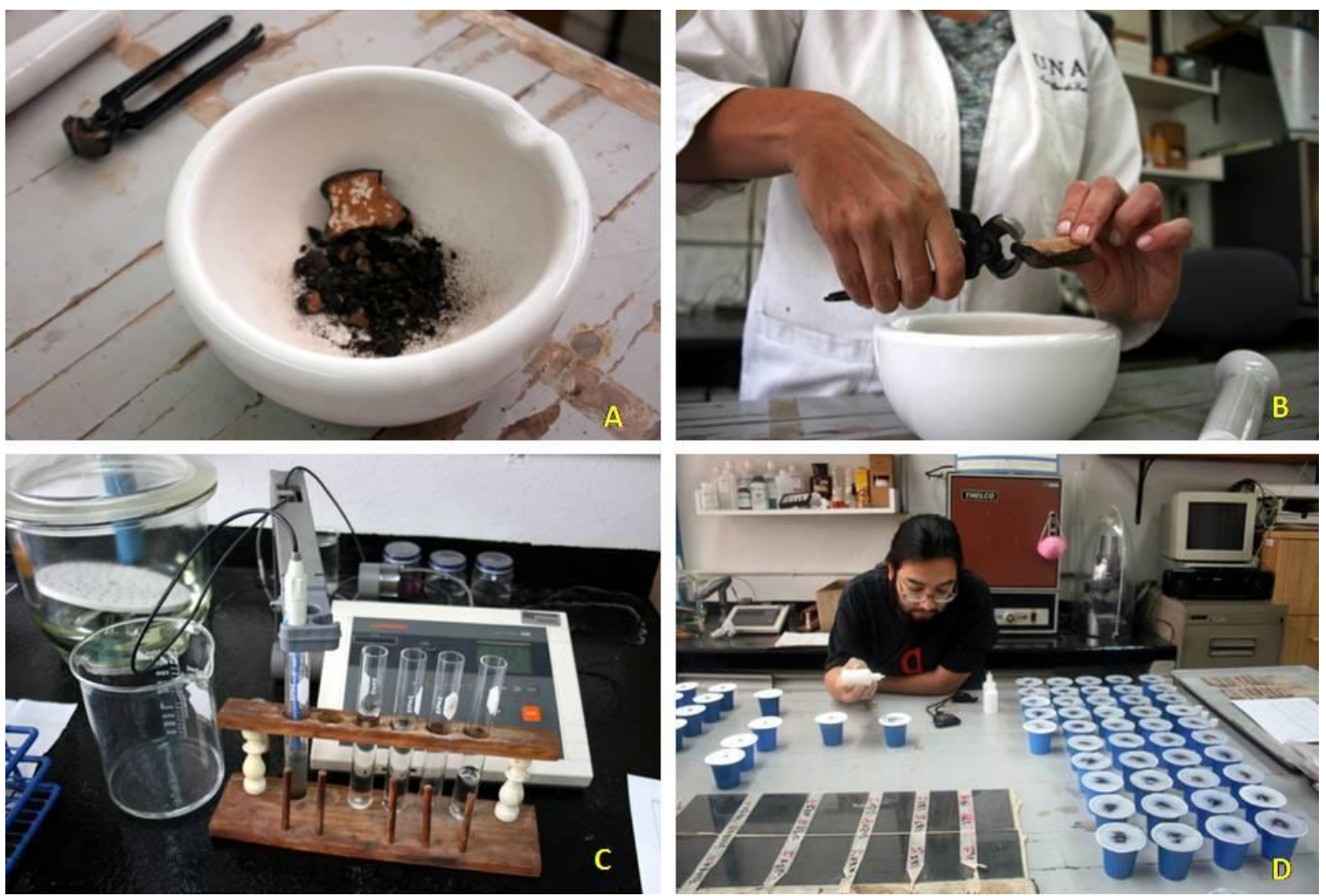

Figura 4.5 - Laboratório de Prospecção Arqueológica (UNAM) - A e B - Preparação da mostra - cerâmica moída no almofariz; $\mathrm{C}$ - Eletrodo para medir o $\mathrm{pH}$ da mostra; D - Análise de fosfato.

\section{Método fluorescência de raios-X}

O método de medida consistiu na emissão de raios X para identificar e medir de forma simultânea, os diferentes elementos químicos inorgânicos presentes no fragmento cerâmico, de forma a permitir inferir a respeito dos elementos majoritários e minoritários da pasta cerâmica.

As medidas foram realizadas com o sistema PXRF-LFNA-03 de medidas de EDXRF portátil do Laboratório de Física Nuclear Aplicada (LFNA/UEL), composto por: detector de raios X tipo Si-PIN (resolução de $149 \mathrm{eV}$ para a linha de 5,9 keV Mn, com janela de Be de 0,5 mil, modelo XR-100CR (AMPTEK Inc,), fonte de alta tensão com amplificador, modelo PX2CR, analisador multicanal modelo MCA8000A, notebook para aquisição e armazenamento dos dados, excitação das amostras com um mini tubo de raios X com alvo de Tungstênio e 4W de potência (10-40kV, 0-100 $\mu \mathrm{A}$, foco de $5 \mathrm{~mm}$ de diâmetro) (MOXTEK Inc.) e um posicionador 
para o conjunto de excitação-detecção com graus de liberdade de translação e rotação. Todo o sistema é portátil e pode ser utilizado para medidas no local de amostragem, como mostra a Figura 4.6. No caso se ser necessário realizar medidas em local sem energia elétrica, o sistema é conectado a um gerador portátil com estabilizador Modelo Honda EU10i (L-P1).

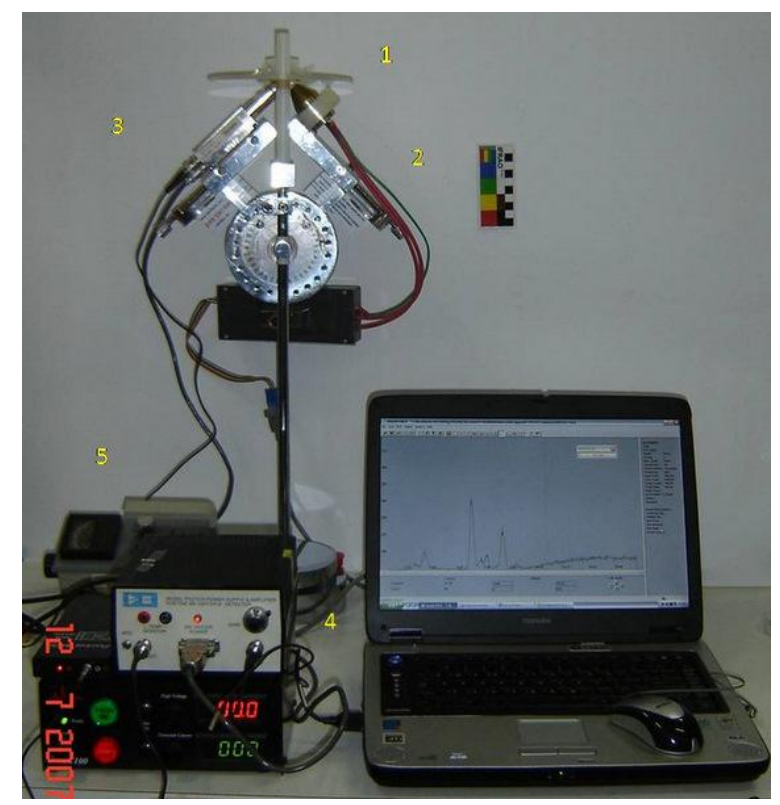

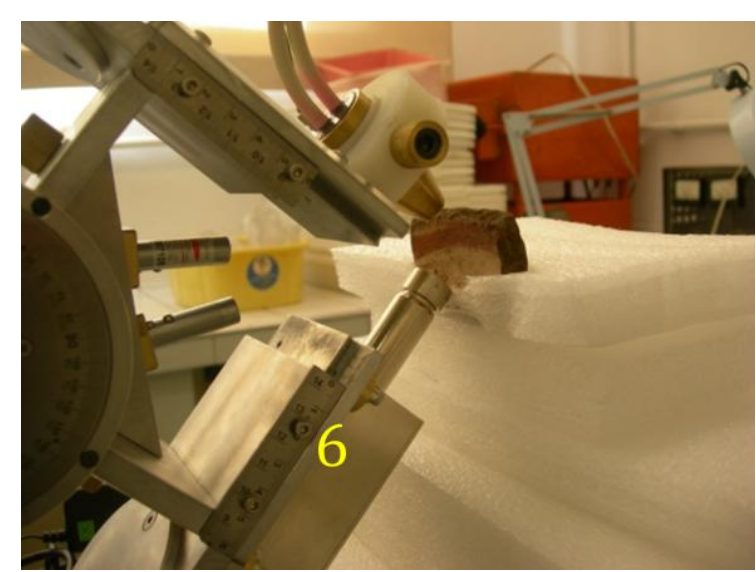

Espectrômetro de raios-X, com fonte de raios- $\mathrm{X}$ e detector

Figura 4.6 - Sistema portátil de EDXRF. (1) amostra, (2) tubo de raios X, (3) detector de raios X, (4) Eletrônica padrão, (5) Contador Geiger Muller para monitoração da área, (6) Espectrômetrode raios-X e detector

As mensurações foram feitas e expressas no espectro no qual os picos (linhas $\mathrm{K} \alpha / \mathrm{K} \beta$ emitidas pelos elementos da amostra) representam a quantidade de raios-X (eixo y) e suas respectivas energias (eixo $\mathrm{x}$ ), nas seguintes condições de medida: tensão no tubo de $10 \mathrm{KV}$ e corrente de $4 \mu \mathrm{A}$. 


\subsection{Resultados e Discussão}

\section{Vestígios químicos}

A tabela 4.1 apresenta um sumário referente aos testes de resíduos químicos. Nela são apresentadas as peças cerâmicas e resultados na forma binária ( 0 - ausência e 1 - presença).

A figura 4.7 está dividida em gráficos de A até E, representando cada prova química aplicada ao conjunto de fragmentos cerâmicos, e apresenta a distribuição de frequiências relativas de cada resultado. É possível perceber uma grande diversidade de resultados, com fragmentos diversos apresentando toda a gama de resultados possíveis. Nota-se uma distribuição dos níveis de fosfato (0-5) quase equivalentes, ressaltando uma quantidade maior com valor quatro e ausência de ocorrências com valor 0 .

Tabela 4.1 - Características das cerâmicas e resultados dos testes de resíduos químicos. C-classe; DPL- decoração plástica; DPI- decoração pintada; RG- resíduos de ácidos graxos; RPresíduos de proteínas; $\mathrm{CO}_{3}$ - carbonatos; $\mathrm{pH}$ - acidez/alcalinidade; $\mathrm{P}$ - fosfato.

\begin{tabular}{cccccccccc} 
N. & PEÇA & C & DPL & DPI & $\begin{array}{c}\text { RG } \\
(0-3)\end{array}$ & $\begin{array}{c}\text { RP } \\
(1-12)\end{array}$ & $\begin{array}{c}\mathrm{CO}_{3^{-}} \\
(0-6)\end{array}$ & $\begin{array}{c}\text { pH } \\
\text { pH da agua }=6,45\end{array}$ & $\begin{array}{c}\text { P } \\
(0-5)\end{array}$ \\
\hline 1 & GR 1949 & BS & 0 & 1 & 0 & 6 & 0 & 6,27 & 5 \\
2 & GR 4605 & B & 0 & 1 & 1 & 6 & 1 & 6,78 & 3 \\
3 & GR 3283 & B & 1 & 0 & 0 & 7 & 1 & 6,64 & 2 \\
4 & GR 2340 & P & 1 & 0 & 1 & 8 & 1 & 6,56 & 3 \\
5 & GR 235 & BS & 0 & 0 & 0 & 9 & 1 & 6,7 & 5 \\
6 & GR 2145 & P & 1 & 0 & 0 & 9 & 1 & 6,29 & 1 \\
7 & GR 315 & B & 1 & 0 & 0,5 & 9 & 0 & 6,91 & 2 \\
8 & GR 2209 & B & 0 & 1 & 0 & 9 & 0 & 6,83 & 5 \\
9 & GR 3524 & B & 0 & 1 & 0,5 & 9 & 0 & 6,98 & 4 \\
10 & GR 1587 & P & 0 & 1 & 0 & 7 & 1 & 7,14 & 4 \\
11 & SEM N & B & 1 & 0 & 0 & 6 & 1 & 7,6 & 1 \\
12 & SEM N & P & 0 & 1 & 0,5 & 6 & 1 & 7,65 & 4 \\
13 & SEM N & P & 0 & 0 & 0,5 & 7 & 1 & 7,23 & 1 \\
14 & GR 3992 & B & 1 & 0 & 0,5 & 7 & 1 & 7,08 & 4 \\
15 & GR 4228 & P & 0 & 1 & 1 & X & 6 & 8 & 3 \\
\hline
\end{tabular}

Segundo a tabela 4.2, observou-se índice de fosfato máximo (cinco) em três fragmentos GR 1949, 235 e 2209 (figura 3 - C, A e D) e valor quatro nos fragmentos - GR 3524, 1587, sem n. e 3992(figura $3-\mathrm{G}, \mathrm{B}$ e N). 
Tabela 4.2 - Classe de fragmentos e distribuição de fosfato - valores 4 e 5.

\begin{tabular}{|c|c|c|c|}
\hline Fragmento & Classe & Valor 5 (fosfato) & Valor 4 (fosfato) \\
\hline R 235 & Base & & \\
\hline GR 1949 & Base & & \\
\hline GR 2209 & Borda & & \\
\hline GR 3524 & Borda & & \\
\hline GR 1587 & Parede & & \\
\hline GR sem número & Parede & & \\
\hline GR 3992 & Borda & & \\
\hline
\end{tabular}

A figura 4.7 - B mostra que a maior parte das cerâmicas não apresentava resíduos graxos, e algumas peças apresentavam pequenas quantidades $(0,5$ e 1,0). Encontrou-se os maiores índices de ácidos graxos (tabela 4.1) em dois fragmentos de parede, ambos com decoração - GR 2340 e 4228 (figura 3 - E e J). Na figura 4.7 - C observa-se que a maior ocorrência de carbonatos, numa escala de 0 a 6, apareceu com valor um e apenas a amostra GR 4228 (figura 3 J) apresentou valor máximo (tabela 4.1). Na figura 4.7- D verifica-se numa escala de 1-12 que a maior quantidade de ocorrências possui valor 9. As demais evidências estão distribuídas de forma equilibrada entre os valores seis e sete, e pouca quantidade com valor 8 .

A tabela 4.3 mostra a ocorrência de altos valores de proteínas (9) em algumas peças, conforme o tipo de decoração.

Tabela 4.3 - Presença de resíduos protéicos com valor 9 dividas por classe e tipo de decoração:

\begin{tabular}{|c|c|c|c|}
\hline Fragmento & Classe & Decoração plástica & Decoração pintada \\
\hline GR 235 & Base & & \\
\hline GR 2145 & Parede & & \\
\hline GR 315 & Borda & & \\
\hline GR 2209 & Borda & & \\
\hline GR 3524 & Borda & & \\
\hline
\end{tabular}


A figura 4.7-E mostra a variação do $\mathrm{pH}$ das amostras e pode-se observar que a maior parte está entre os valores de 6 a 7, apenas o fragmento GR 4228 (figura 3 - J) apresentou valor oito de pH (tabela 1), porém não é um valor consideravelmente alto.
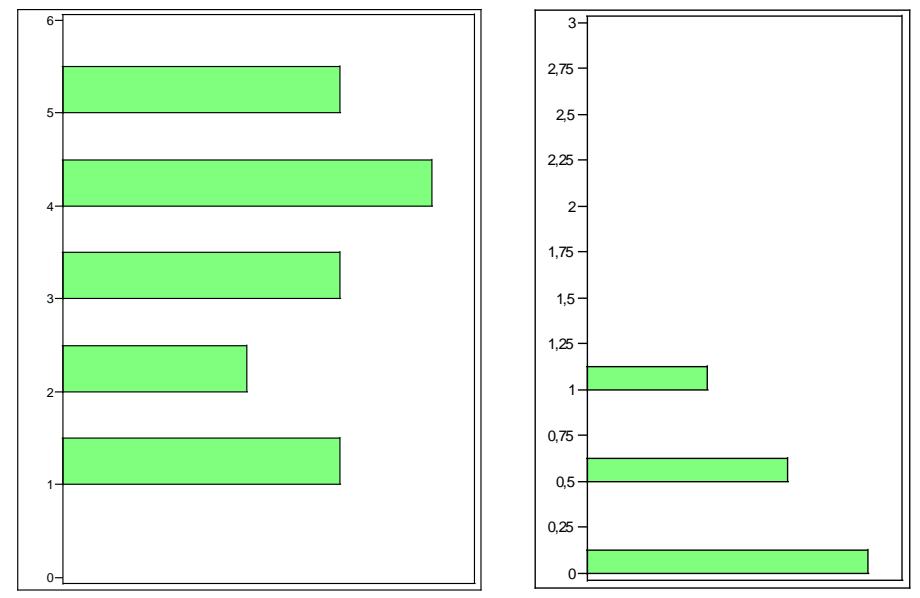

A -fosfato

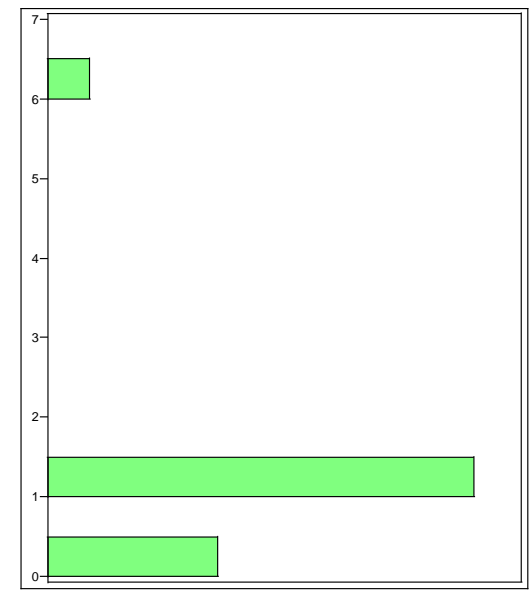

C - Carbonatos
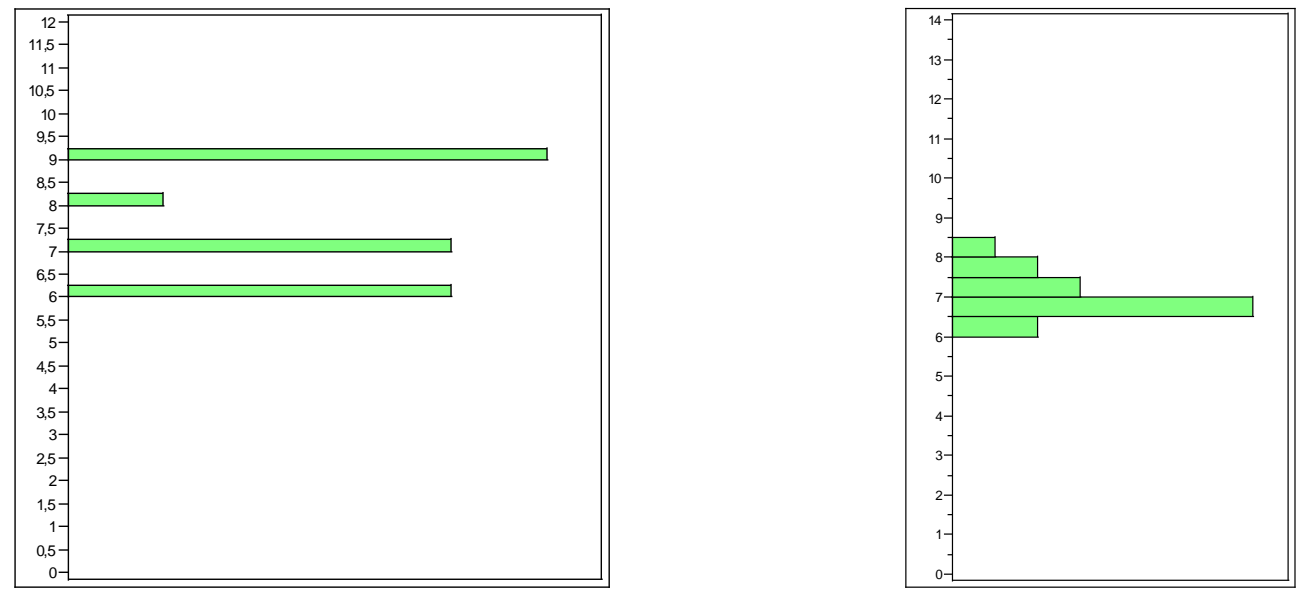

\section{D - Resíduos protéicos}

$$
\mathrm{E}-\mathrm{pH}
$$

Figura 4.7 - Distribuição de frequiências relativas dos resíduos químicos no conjunto das cerâmicas.

Na figura 4.8 observamos uma diferença estatisticamente significativa entre fragmentos com decoração plástica e ausência ou presença de fosfato. Verificou-se que a decoração plástica, tanto em bordas, como paredes apresentou baixa ou quase nula presença de fosfato. 


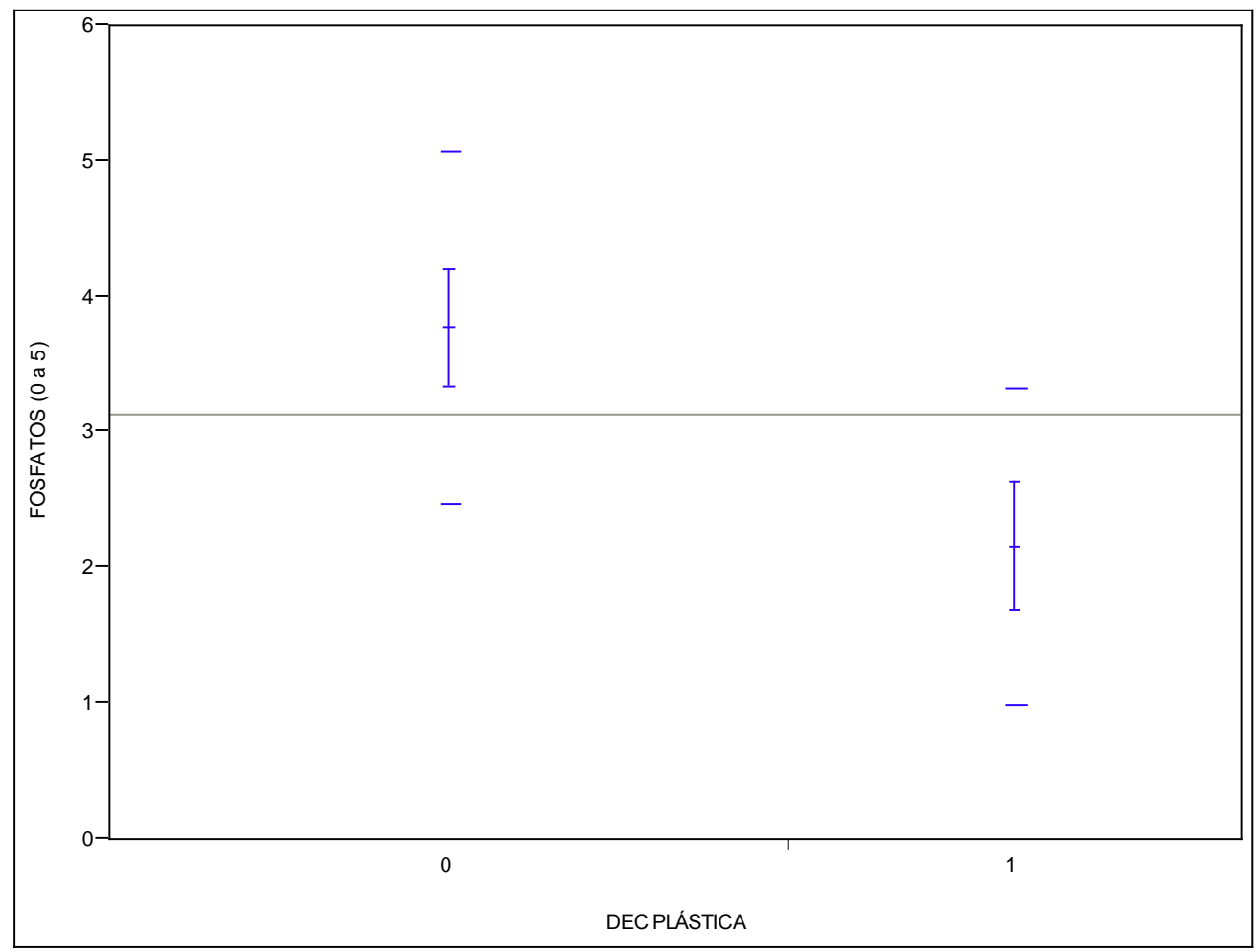

Figura 4.8 - Distribuição da decoração plástica e fosfato (barra central é a média, $1^{\mathrm{a}}$ barra horizontal é o erro padrão da média e as barras periféricas é o desvio padrão).

Na figura 4.9 observa-se uma diferença significativa entre os fragmentos com decoração pintada e a presença de fosfato. Os fragmentos com pintura, tanto bordas, como paredes, apresentaram grande quantidade de fosfato.

$\mathrm{Na}$ figura 4.10 verifica-se que o fragmento GR 4228 (figura 3 - J) apresentou uma diferença estatística dos demais, tanto no que diz respeito à presença de carbonatos, como de $\mathrm{pH}$. 


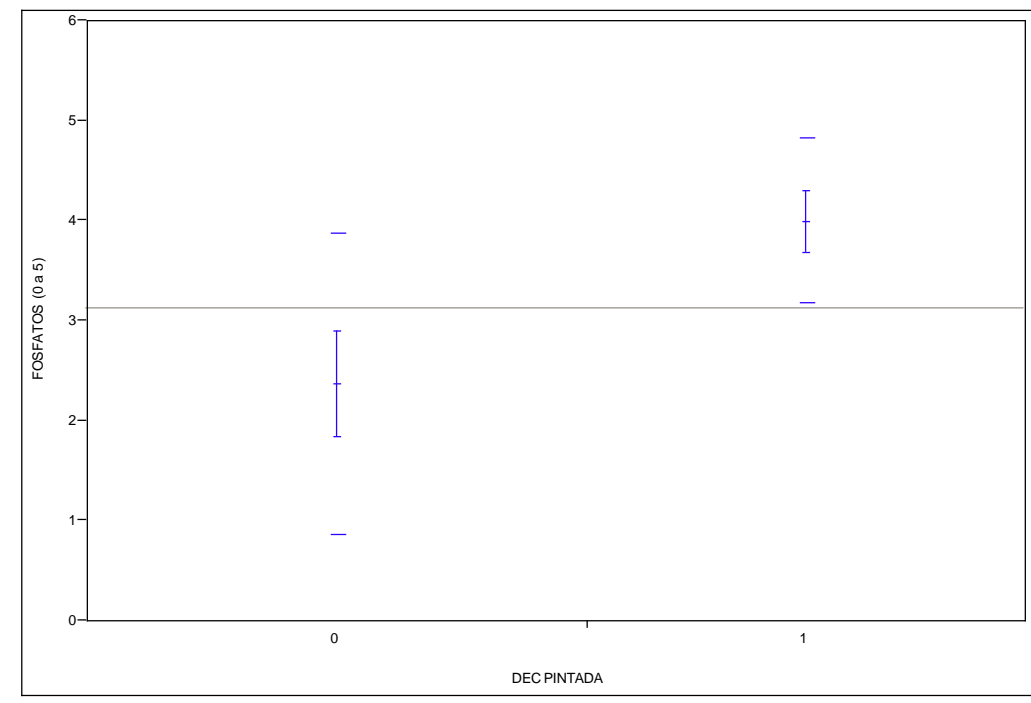

Figura 4.9 - Distribuição da decoração pintada e fosfato. (barra central é a média, $1^{a}$ barra horizontal é o erro padrão da média e as barras periféricas é o desvio padrão).

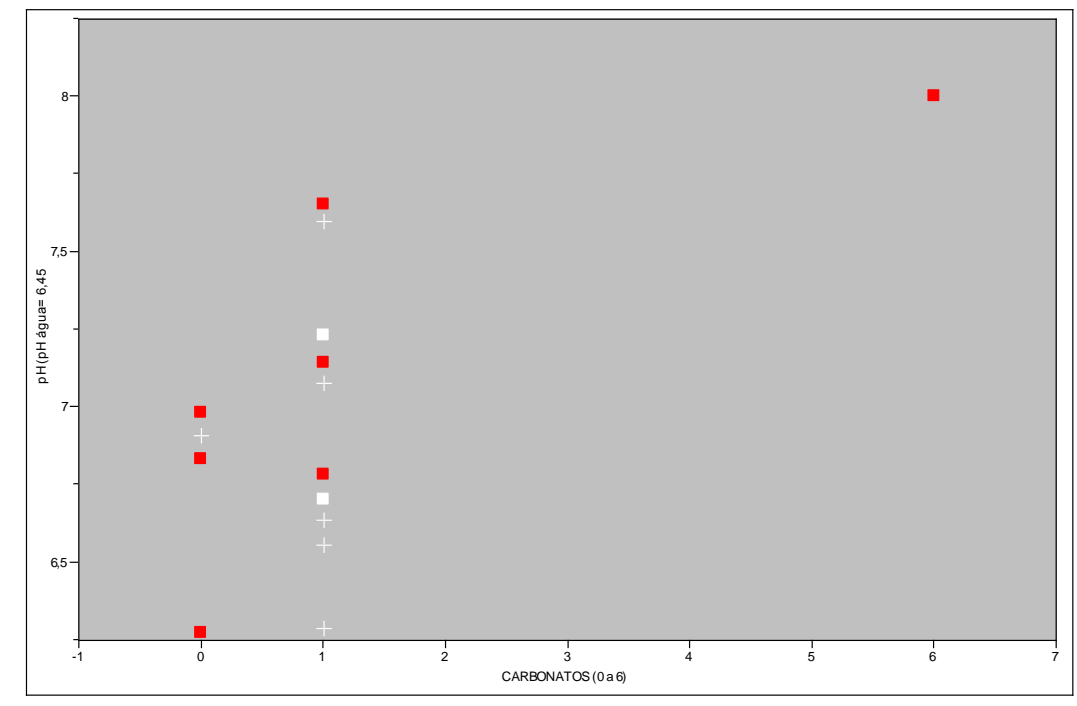

Figura 4.10 - Distribuição de carbonatos e pH.

Na figura 4.11 abaixo observa-se a comparação entre carbonatos e resíduos graxos e é evidente que o fragmento GR 4228 (figura 3 - J) destaca-se estatisticamente de forma significativa dos demais. 


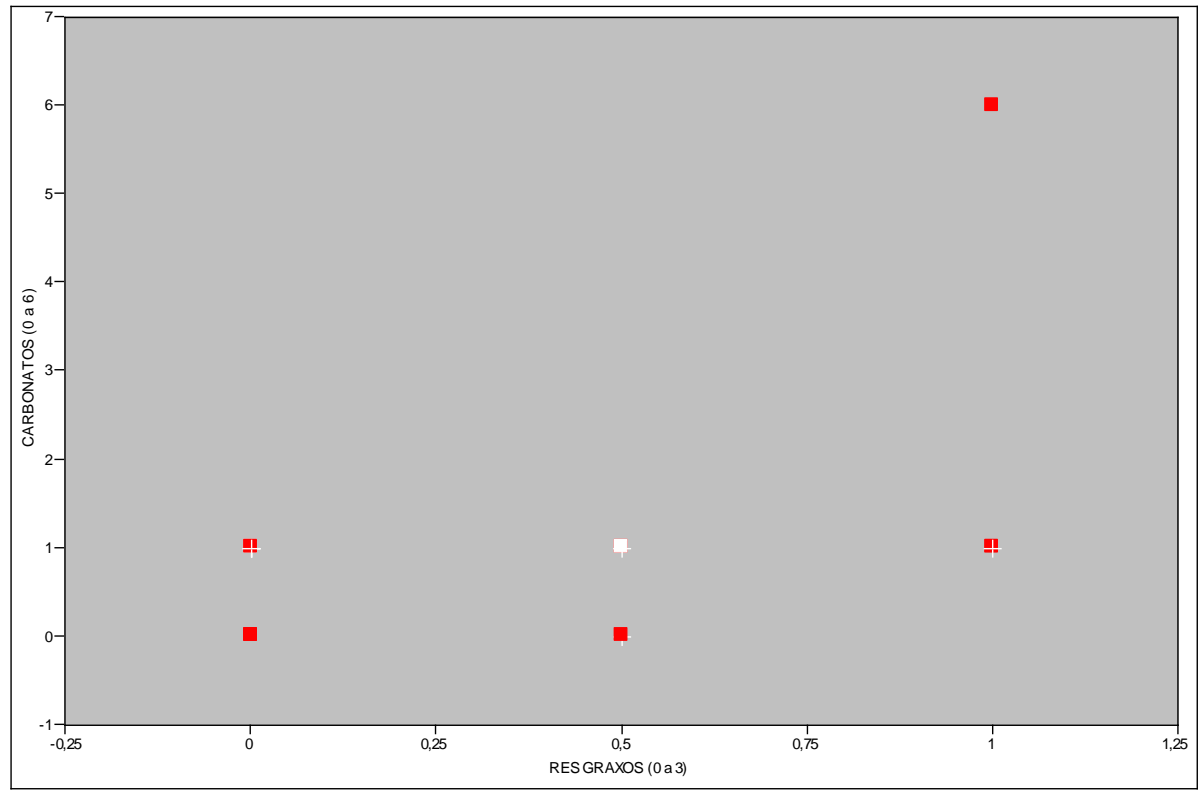

Figura 4.11 - Distribuição de carbonatos e ácidos graxos.

\section{Fluorescências de raios-X}

Esse tipo de análise gera espectros de raios-X, como o exemplo da figura 4.12, que não são de interpretação intuitiva. Assim, a figura 4.12 será empregada para explicar como os espectros seguintes devem ser interpretados. $\mathrm{O}$ eixo y apresenta as contagens para cada energia de raios $\mathrm{X}$ e o eixo $\mathrm{x}$ a energia dos raios $\mathrm{X}$ de resposta de cada elemento químico detectado (Ar, $\mathrm{Fe}, \mathrm{Mn}, \mathrm{Ti}, \mathrm{Si}$ ), chamados de raios $\mathrm{X}$ característicos. Cada elemento é identificado por um ou dois picos, denominados $\mathrm{K} \alpha \mathrm{e} \mathrm{K} \beta$, que correspondem às camadas eletrônicas que são excitadas pelos raios-X e que emitem energia na forma de fluorescência. Assim, nesses espectros são identificados picos dos seguintes elementos, da esquerda para a direita: $\mathrm{Si}, \mathrm{Ar}, \mathrm{K}, \mathrm{Ca}, \mathrm{Ti}, \mathrm{Mn}$ e Fe. Apenas Ar não é de interesse, visto que é um pico gerado em resposta à presença desse elemento no ar atmosférico existente entre a amostra e o detector. Assim, os demais são elementos típicos dos minerais que compõem a pasta de argila ou o engobo. 


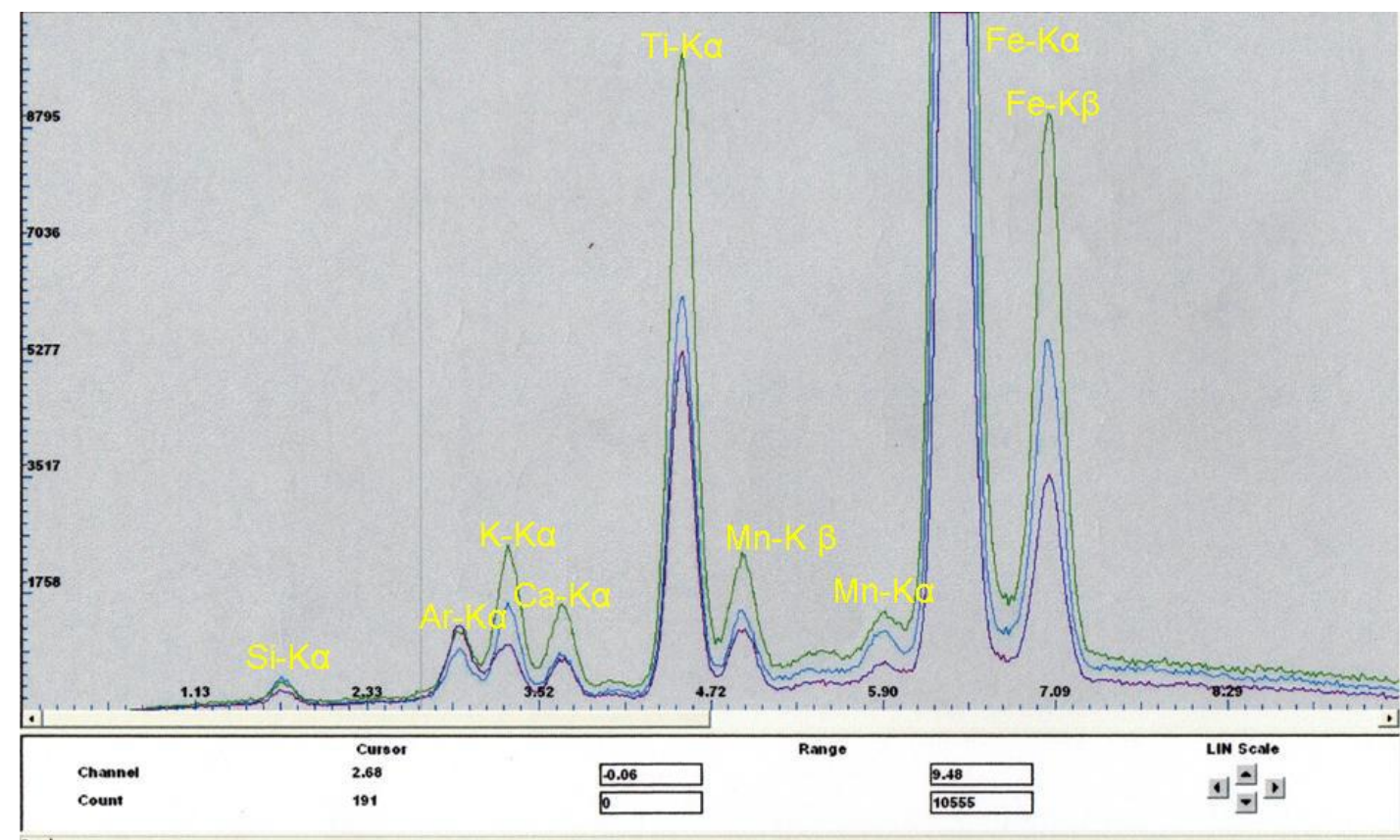

Figura 4.12- Espectro de fluorescência de raios-X. Exemplo de espectro de análise de comparação entre pigmentos de cerâmica e pasta. Linha verde= fundo branco, medida B; Linha lilás= listra preta, Linha azul= pasta, medida $\mathrm{a} . \mathrm{K} \alpha, \mathrm{K} \beta$ correspondem às linhas de fluorescência para diversos elementos: $\mathrm{Fe}=$ ferro; $\mathrm{Si}=$ silício; $\mathrm{Ar}=$ argônio; $\mathrm{Mn}=$ manganês; $\mathrm{Ti}=$ titânio

Na figura 4.13 - A temos a comparação entre dois pigmentos vermelhos, sendo que um deles apresenta pintura na face interna (GR 1406), enquanto o outro a pintura apresenta-se na face externa como acabamento (GR 4663). O espectro demonstra que não existem diferenças entre os dois pigmentos. No entanto, o fragmento GR 4663 apresentou potássio em sua pasta que, pode ser proveniente da própria argila (argila de melhor qualidade para sinterizar cerâmica) ou ocorreu adição intencional de cinzas. 

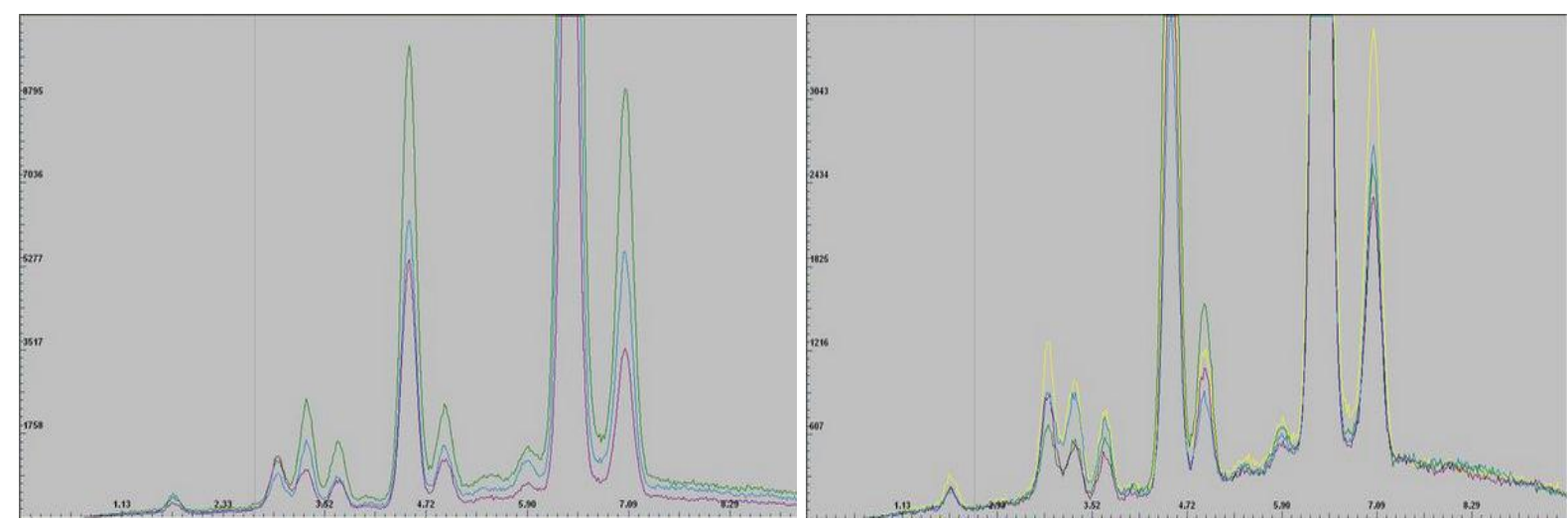

A

B

Comparação de espectro de raios-X de pigmentos vermelhos e pasta cerâmica. Fragmentos GR1406 e GR4663. No espectro apresentado as linhas correspondem: linha verde - GR4663 pigmento vermelho; linha lilás - GR 4663 pasta; linha azul GR1406 pigmento vermelho.
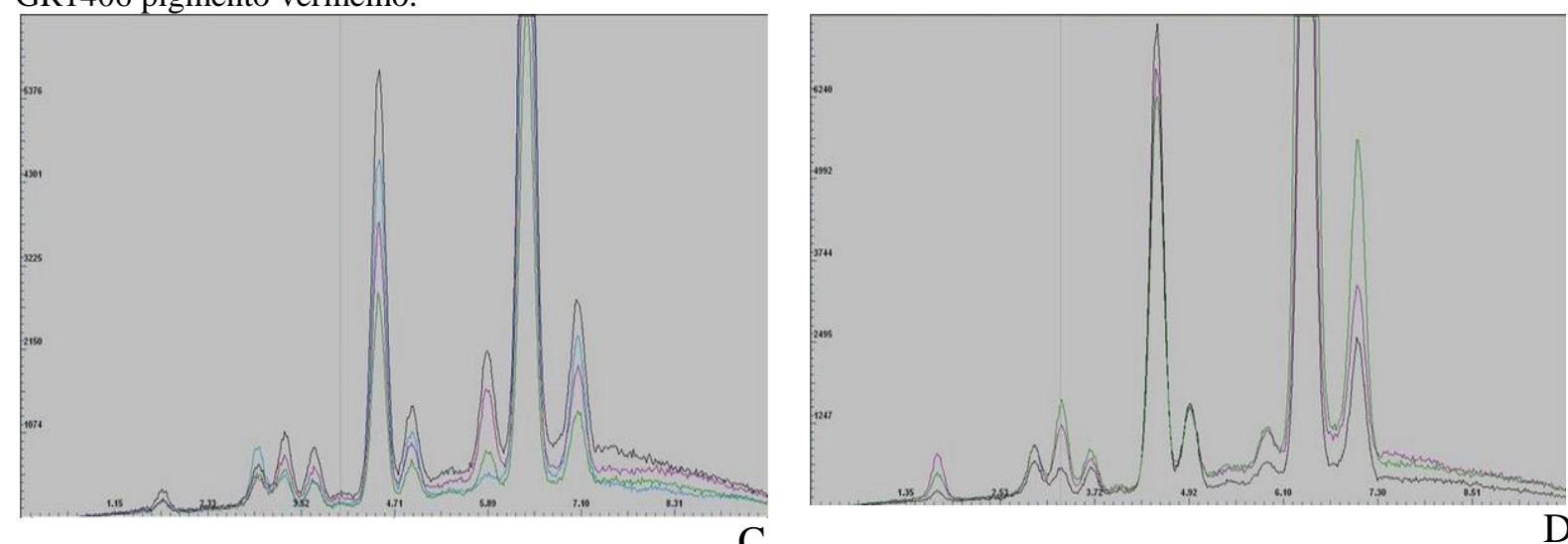

C

Comparação de espectro de raios-X de pasta Comparação de espectro de raios-X de pasta cerâmica, pigmento preto e pigmento branco. cerâmica, pigmento vermelho e pigmento branco. Fragmento GR 238. Linha azul - pasta, linha verde - Fragmento GR 1406. Linha verde - vermelho; linha fundo branco, linha lilás - listra preta e linha preta - lilás - branco e linha preta - pasta. listra preta.

Na figura 4.13 são apresentados quatro espectros de raios-X relacionando pastas cerâmicas e pigmentos.

Na figura 4.13 - B não foi observada alteração de composição da pasta entre os fragmentos GR 270, 1406, 238 e 4663.

$\mathrm{Na}$ figura 4.13 - C o pigmento preto apresentou óxido de manganês, enquanto o pigmento branco apresentou silício aumentado. Não se constatou aumento de dióxido de titânio (comum nos pigmentos brancos).

Na figura 4.14 são apresentados quatro fragmentos comparando a pasta cerâmica e seus respectivos espectros de raios $\mathrm{X}$ 


\section{GR 2316}
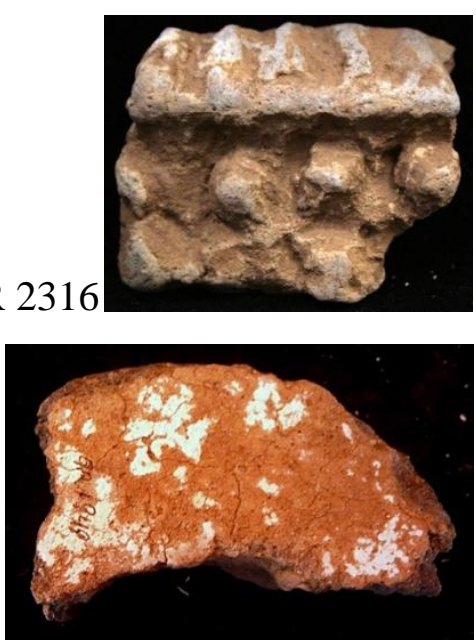

GR 1583

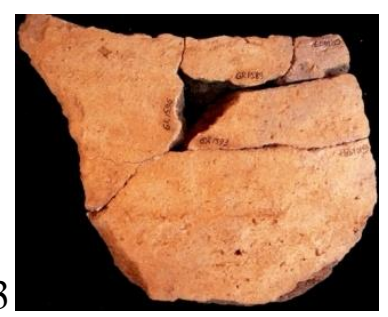

GR 3547

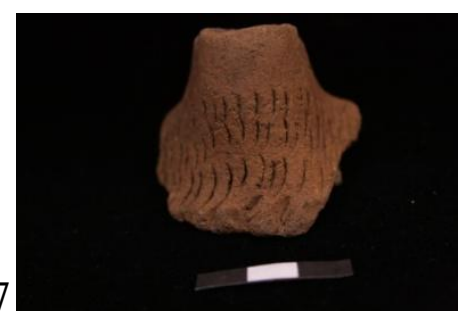

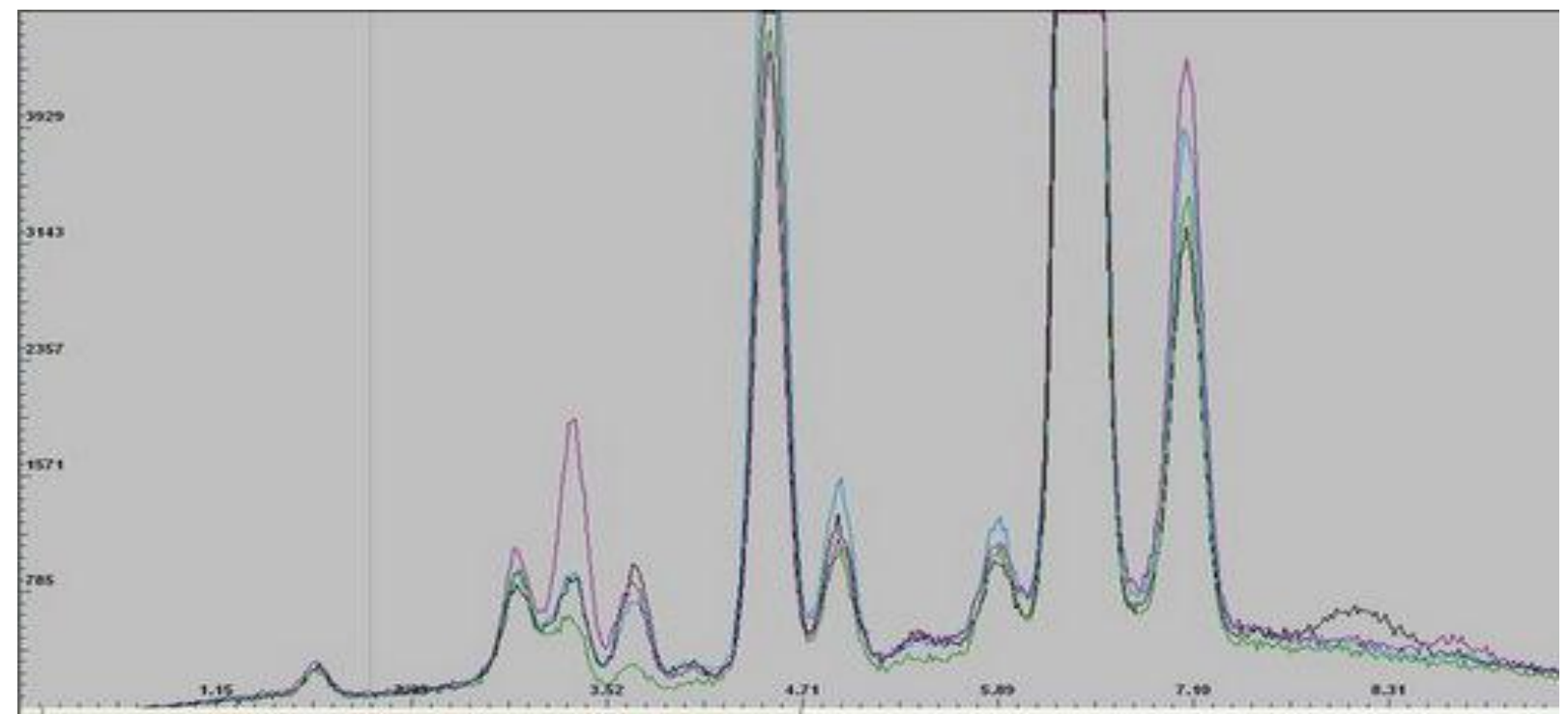

Figura 4.14 - Comparação de espectro de raios-X de pastas cerâmicas. Linha azul - fragmento 3542, linha verde fragmento 2316, linha lilás - fragmento 1949 e linha preta - fragmento 1583.

Na figura 4.14 observa-se que a pasta cerâmica do fragmento GR 1949 apresentou potássio aumentado comparado aos demais fragmentos.

A partir os dados apresentados é possível discutir alguns aspectos relevantes sobre a cerâmica do sítio Gramado. Segundo Barba e Mejía-Pérez (1994), os altos valores de pH indicam a presença de exposição ao fogo e cinzas provenientes da queima de madeira. Nas áreas de atividade da região de Cobá (Quintana Roo - México) realizadas por eles, as análises químicas e o alto valor de $\mathrm{pH}$, juntamente com as características de estrutura e localização geográfica, bem como a evidência de pouca quantidade de cerâmica utilitária permitiram definir a área de estudo como santuário familiar e local de rituais. 
Tabela 4.4 - Resultado de ocorrência de elementos químicos em cada fragmento.

\begin{tabular}{|c|c|}
\hline Fragmento & Resultado \\
\hline \multirow[t]{6}{*}{ GR 1406} & $\begin{array}{l}\text { Faixa e pigmento vermelho lado côncavo: } \mathrm{Si}, \mathrm{K}, \mathrm{Ca}, \mathrm{Ti}, \mathrm{Mn} \text {, } \\
\mathrm{Fe}\end{array}$ \\
\hline & Pasta cerâmica - Medida pelo lado convexo: \\
\hline & - para vermelho é quantidade de Fe \\
\hline & - para branco é quantidade Si e K - argila branca com silicato \\
\hline & $\begin{array}{l}\text { - corte transversal irregular. A priori: } \\
\text { - vermelho é quantidade de Fe }\end{array}$ \\
\hline & - branco é quantidade Si e K - argila branca com silicato \\
\hline \multirow[t]{4}{*}{ GR 238} & - Fundo branco (dúvida sobre o foco). \\
\hline & Razão pico $\mathrm{Mn} / \mathrm{Fe}===$ (d) \\
\hline & $\begin{array}{llll}0.1627 & 0.1248 & 0.1284 & 0.0468\end{array}$ \\
\hline & Tinta preta - indicação é óxido de Mn \\
\hline GR 2316 & Análise da Pasta lado côncavo - picos para Fe, $\mathrm{K}$ e Ca \\
\hline \multirow[t]{2}{*}{ GR 4663} & Medida do engobo vermelho - região convexa \\
\hline & Medida da pasta cerâmica - área quebrada região côncava \\
\hline GR 270 & Medida da pasta cerâmica - picos para $\mathrm{Fe}, \mathrm{K}$ e Ca \\
\hline GR 1583 & $\begin{array}{l}\text { Medida da pasta cerâmica / lado convexo - picos para Fe, K e } \\
\mathrm{Ca}\end{array}$ \\
\hline GR 1949 & $\begin{array}{l}\text { Medida da pasta cerâmica - lado convexo - picos para } \mathrm{Fe}, \mathrm{Ke} \\
\mathrm{Ca} \text { com destaque para maior proporção de } \mathrm{K}\end{array}$ \\
\hline GR 3547 & $\begin{array}{l}\text { Medida da pasta cerâmica - corte transversal - picos para Fe, } \\
\mathrm{K} \text { e Ca }\end{array}$ \\
\hline
\end{tabular}

No sítio Gramado o fragmento GR 4228 (figura 3 - J) apresentou $\mathrm{pH}=8$ acompanhado de um valor elevado de carbonato (6), destoando de forma significativa dos demais fragmentos, porém o valor de $\mathrm{pH}$ não é suficientemente alto para afirmar a presença de combustão, mas sim a carbonatação da cerâmica. A carbonatação ocorre por uma reação química em que a cerâmica pode conter sais (seja da sua própria pasta ou do meio onde foi retirada) e, ao contato com a água podem apresentar-se na superfície da cerâmica, provocando um aumento de $\mathrm{pH}$, mas que normalmente provêm de cálcio ou sulfatos de cálcio.

Barba e Mejía-Pérez (1994) ao descrever uma área habitacional do sítio arqueológico de Cobá (Quintana Roo - México) apontam que o alto índice de carbonatos no solo podem ser indicadores da abundância de estruturas construídas com cal que, ao desintegrar-se, misturam-se com o solo. A concentração de resíduos químicos como fosfato e $\mathrm{pH}$ em uma das áreas foi interpretada como ocorrência de uma variedade de atividades domésticas associadas com fontes de calor e consumo de alimentos. 
Segundo Barba e Pérez (1994) a presença de fosfato em áreas habitacionais indica atividade de preparação e consumo de alimentos. Podemos inferir sobre a possibilidade dos fragmentos GR 235 e GR 2209 terem sido utilizados para esse fim, graças à combinação de fosfato e resíduos protéicos apresentados de forma elevada.

Já o fragmento GR 1949 apresentou valores baixos para todas as provas, exceto na prova de fosfato, com isso levanta-se a hipótese de se tratar de um recipiente para dejeções, porém a análise da pasta cerâmica por espectros de raios-X demonstrou que esse fragmento possui aumento da presença de potássio, o que torna a cerâmica mais impermeável. Portanto, comparando as duas análises pode-se levantar a hipótese de tratar-se de outra fonte de argila.

Os resultados apresentados na tabela 2 mostram que existe uma relação direta entre presença de fosfato e decoração nas cerâmicas do sítio Gramado. As bordas com decoração pintada GR 2209 e GR 3524 apresentaram maior concentração de fosfato e também alto índice de resíduos protéicos, podendo indicar a presença de carne, ossos ou sangue e, devido ao tamanho das vasilhas, descarta-se a utilização para armazenamento de alimentos, podendo sugerir a sua utilização em eventos rituais.

As cerâmicas com decoração plástica apresentaram pouca ou quase inexistência de fosfato, exceto o fragmento GR 3992 (figura $3-\mathrm{H}$ ).

Com relação aos resíduos protéicos, observou-se que dois fragmentos GR 315 e GR 2145 possuíam índice elevado (figura 3 - M e L), além de possuírem características formais semelhantes: vasilhas pequenas com espessura fina.

Ao todo a análise química do sítio Gramado mostrou que apesar de um número reduzido de amostras, a cerâmica apresentou variedade considerável de resultados químicos. Observou-se uma diferença significativa estatisticamente de presença de fosfato entre as cerâmicas com decoração pintada e plástica, porém existe uma característica comum entre elas, todos os fragmentos decorados e com alto índice de resíduos protéicos constituem-se de vasilhas pequenas. O fragmento GR 4228 (figura 3 - J) destoou dos demais por apresentar carbonatação na cerâmica.

Quanto à análise de fluorescência de raios-X, observou-se que o pigmento vermelho não apresentou variação em seus elementos, tanto nas pinturas externas, como internas. No pigmento branco constatou-se a presença de silicato, demonstrando a utilização de pigmento mineral estável durante a queima. 


\subsection{Conclusão}

Verificou-se que alguns dos fragmentos apresentaram composição da pasta e uso distintos. Pelas evidências das análises de vestígios químicos e fluorescência de raios-X, observou-se que algumas peças apresentaram pastas diferentes das demais, com isso pode-se concluir que mesmo vivendo num mesmo ambiente, o grupo fez escolhas diferentes com relação à argila ou trata-se de fragmento trazido de outro lugar. Além disso, observou-se que os pigmentos utilizados para a pintura eram de origem mineral e resistentes a queima cerâmica, com isso reforça-se a idéia de se tratar de pintura realizada antes da cozedura. Quanto à utilização dos vasilhames, constataram-se usos distintos entre as cerâmicas com decoração plástica e pintada. 
Marianne Sallum, 2011

Estudo do Gesto em Cerâmicas do Sítio Gramado

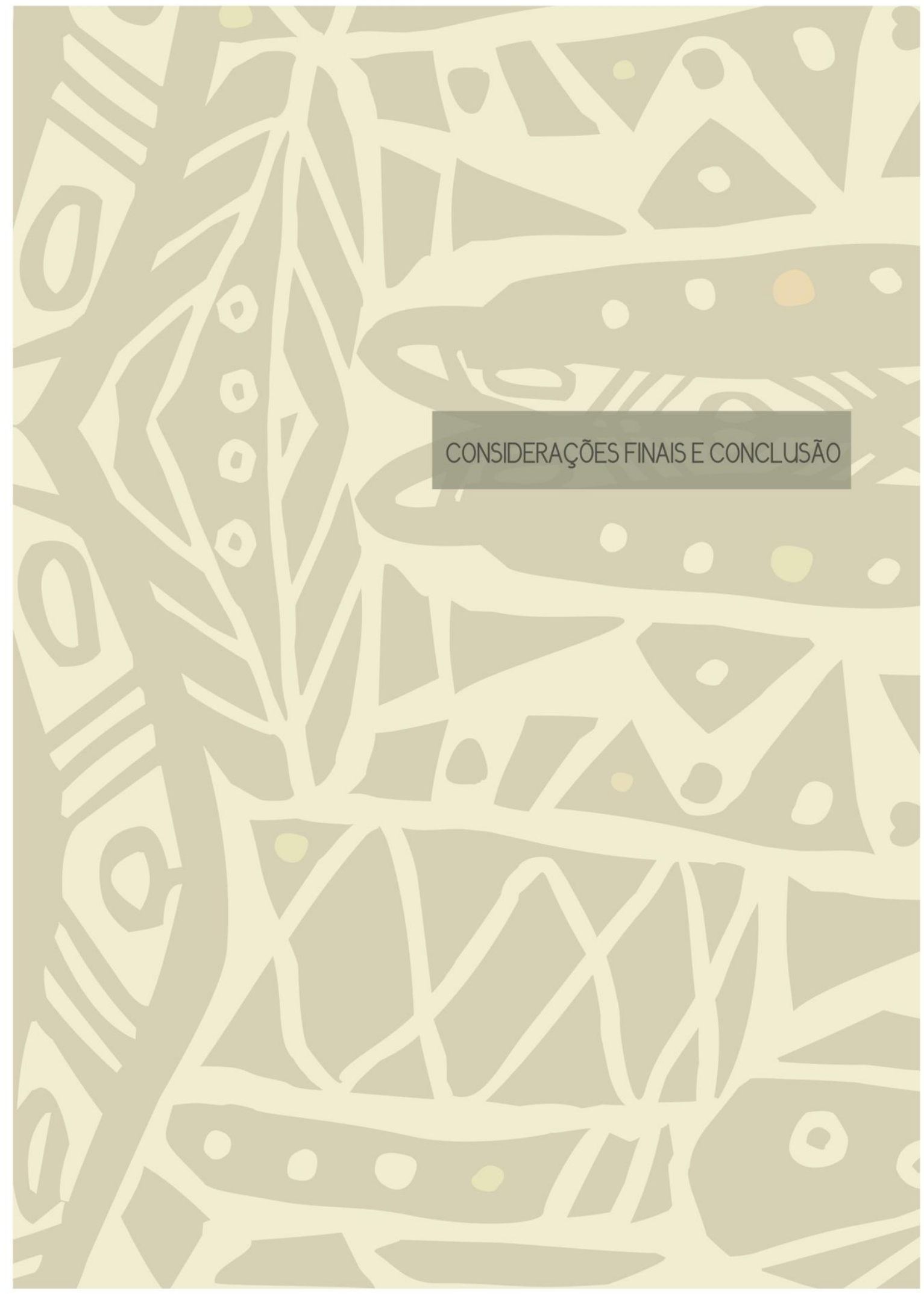




\section{Considerações finais}

A discussão conjunta dos resultados e conclusões desta dissertação foi construída a partir da base teórica de Mauss (1974) e Skibo (1992), que afirmam que o estudo do gesto permite compreender aspectos sociais de um grupo. Outros autores como Lemonier (1992, 2002), Bedoucha (2002), Cresswell (2002), Quilici-Pacaud (2002) e van der Leeuw (2002) também consideram que a escolha técnica é influenciada por um amplo arco social e simbólico (Skibo e Schiffer, 2008).

O fato da existência de grande quantidade de material cerâmico em reservas técnicas de museus e muitos com datações bem recuadas demonstram como esta tecnologia avançou no tempo e isso se deveu, principalmente, pelo processo de manufatura e queima da cerâmica (Cerezer, 2009).

Com relação à cerâmica do sítio Gramado, chama a atenção o grande número de fragmentos cerâmicos encontrados em superfície e sub-superfície. A escavação foi realizada em uma área ampla com duas concentrações de material cerâmico. Em 2009 durante visita ao sítio, foram observadas outras áreas de concentração de material em superfície. Além disso, a fazenda está próxima ao rio Jacaré-Pepira, onde foi encontrado material lítico arqueológico (apresentado no capítulo 1). O sítio arqueológico Gramado e seu entorno merece ser melhor explorado, pois além da quantidade considerável de material arqueológico, localiza-se em local estratégico para entender a ocupação Tupi no Estado de São Paulo.

A análise de atributos cerâmicos permitiu conhecer em detalhes o material e contribuiu para apontar aspectos passíveis de serem respondidos pela experimentação, como: quais são as técnicas de manufatura empregadas e quais os motivos das quebras entre roletes; quais são as formas de tratamento de superfície; os tipos de decoração, a utilização de engobo e pintura, a relação entre espessura e forma. Observou-se que as cerâmicas mais finas estavam ligadas às decorações unguladas, enquanto as médias e espessas foram encontradas principalmente nos fragmentos com pintura e decoração corrugada.

A planilha de dados de Moraes (2007) serviu de base para o início da pesquisa, mas foi aprimorada a fim de atender às características peculiares do material aqui estudado, bem como para obter maior precisão das análises. Como essa abordagem não era o foco principal da dissertação optou-se por não se aprofundar demais no detalhamento dos atributos. No entanto, o material proporcionava rica amostragem para um estudo aprofundado de atributos, mas que aqui serviram para identificar tipos freqüentes de tecnologia, a fim de montar uma estrutura de estudo para a experimentação, bem como entender passos da cadeia operatória. 
A pesquisa de atributos permitiu também identificar características particulares da cerâmica do sítio Gramado e compará-las com a bibliografia sobre o assunto. Com isso, foi possível afirmar que a cerâmica associava-se de fato à tradição Tupiguarani, graças aos seus aspectos tecnológicos e decorativos, tais como: pinturas com fundo branco e linhas pretas paralelas com linhas transversais mais curtas, linhas verticais ou obliquas compondo triângulos, faixa vermelha, todas aplicadas usando a técnica do engobo. Quanto às decorações plásticas, há a presença maciça dos tipos corrugado e ungulado.

A pesquisa com experimentação, inicialmente, seguiu as regras propostas por Coles (1973), descritas na introdução do capítulo 3, porém no decorrer do trabalho, elas foram adaptadas às necessidades e condições da cerâmica do sítio Gramado.

Sobre a utilização de materiais que tivessem relação com os encontrados arqueologicamente, foram escolhidos instrumentos facilmente recolhidos na natureza para a confecção e acabamento das peças. $\mathrm{O}$ critério de seleção da argila foi baseado em aspecto como coloração e barro compatível para uma queima em baixa temperatura (até $1200^{\circ} \mathrm{C}$ ). No entanto, os experimentos de cozedura ficaram restritos ao uso de um forno a gás. A utilização de tecnologia moderna para queima forneceu base de comparação com o procedimento arqueológico, principalmente na discussão sobre a relação entre cor da cerâmica, queima redutora e queima incompleta, concluindo que a cor da cerâmica está ligada à falta de oxigênio durante a queima.

Dessa forma, concordando com Coles (1973), a tecnologia moderna foi utilizada como aporte da metodologia de trabalho contribuindo para pensar sobre os resultados atingidos com a queima que enriqueceram a discussão, sem comprometer a etapa de pesquisa.

A definição prévia de qual seria a extensão da experimentação necessitou ser refeita diversas vezes durante os estudos. Primeiramente, constatou-se a complexidade de dominar a técnica da cerâmica ao ponto de propor hipóteses. Além disso, todas as etapas do fazer cerâmica exigem tempo de trabalho, bem como tempo de descanso da matéria prima ou peça em construção, ou seja, não é possível avançar muitas etapas de labor num mesmo dia. A aceitação dessa premissa e a experiência adquirida no decorrer do trabalho possibilitaram controlar melhor o tempo conforme a pesquisa avançava.

O trabalho com o barro pode sofrer a influência de diversos fatores não controláveis pelo artesão, como é o caso da temperatura ambiente. Um tempo muito úmido, por exemplo, modifica todas as etapas de experimentação, desde a preparação da argila até a secagem de uma peça. Além disso, o material também reflete a disposição e a experiência do artesão. Por esses motivos, conclui-se que a repetição na experimentação fornece dados importantes na comparação 
de resultados e elaboração de perguntas. A repetição da experimentação, apregoada por Coles (1973), também é importante por outra razão: a qualidade do trabalho do artesão, bem como do arqueólogo experimentador, evolui ou regride com a prática, ou falta dela, respectivamente. Assim, repetir a experimentação não só aumenta a compreensão do processo em si e de sua cadeia operatória, mas também aumenta a habilidade e, portanto o domínio do oleiro (artesão/experimentador) sobre o resultado obtido.

Durante toda a pesquisa com experimentação foi de suma importância a consulta bibliográfica, bem como as conversas com ceramistas e arqueólogos. Novamente concordando com Coles (1973), os resultados, por si só, não constituem uma prova absoluta, mas sim, fornecem pistas e questões discutir.

Durante a experimentação, investiu-se grande parcela de tempo tentando reproduzir com fidelidade tipos de decoração, tanto plástica quanto pintada. A integração da análise detalhada de atributos com a experimentação trouxe avanços importantes de interpretação, com resultados originais. Por exemplo, foi esclarecido que as pinturas, tanto fundo branco, como listas vermelhas e pretas, das cerâmicas arqueológicas foram aplicadas pela técnica do engobo, portanto foram feitas antes da queima. Isso é importante de perceber, pois mostra que a decoração pintada é uma atitude de expressão aplicada no momento exato que a cerâmica atinge o ponto de couro e está úmida o suficiente para absorver e reter bem o pigmento. Não é algo feito depois da queima. Tem um momento específico para ocorrer, do contrário não vai funcionar. Assim na cadeia, essa etapa faz parte da fase de acabamento (aplicação de camada fina de pigmento) e decoração (pintura) de uma peça cerâmica. Isso exige do artesão intencionalidade e planejamento. Não pode ser feito de improviso ou a qualquer momento depois que a peça secou. Tem que ser feito no ponto de couro e os pigmentos tem que estar prontos para a aplicação no momento certo, quase como o que é necessário para aplicar um afresco sobre o gesso. 


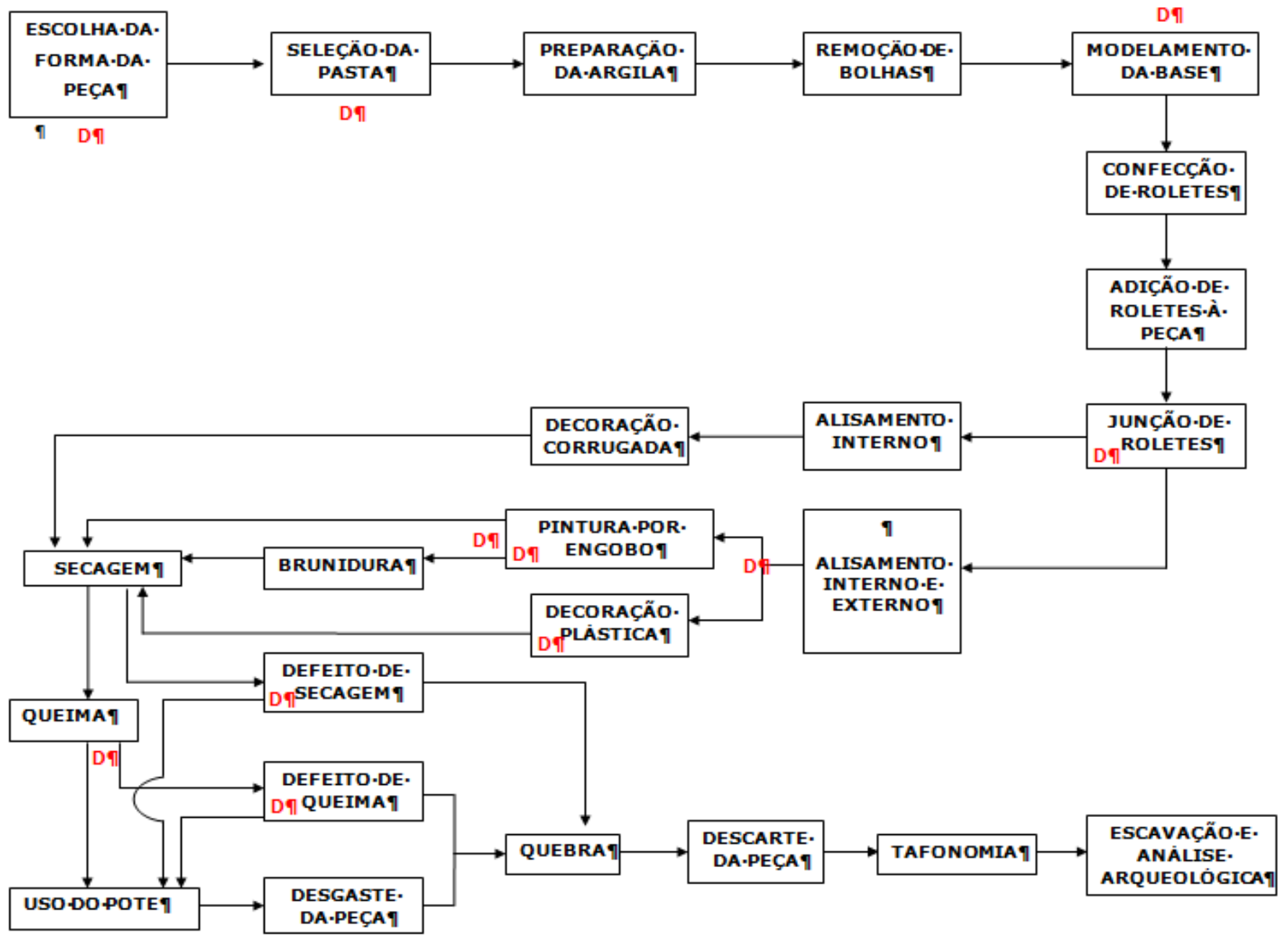

Figura 5.1 - Fluxograma representando os passos da cadeia operatória do trabalho oleiro de uma cultura Tupiguarani. As letras "D" representam etapas ou passagens em que ocorre uma decisão importante. 
Da mesma forma, foi evidenciado que a decoração corrugada está relacionada à junção dos roletes e que algumas decorações plásticas muito regulares devem ter sido produzidas com auxílio de instrumentos simples, como segmentos de madeira. Assim a formação da decoração corrugada é um gesto não trivial, nem frívolo, mas resultado de um passo necessário para a junção do rolete, que ao mesmo tempo pode ser uma escolha decorativa. As cerâmicas com decoração corrugada-espatulada e corrugada-ungulada confirmam essa idéia, pois se observa claramente a intencionalidade do gesto. Prosseguir alisando mais a cerâmica até obter uma peça completamente lisa, posteriormente pintada com aplicação de engobo e ainda brunida para ter um acabamento mais brilhante ainda. Será que há um valor expresso nessa cadeia? Peça mais complexa, mais etapas, seriam para uma finalidade mais valiosa? Comida, armazenamento, ritual ou sepultamento?

As questões apresentadas acima confirmam que o estudo de arqueologia experimental proporciona a compreensão de elementos sutis do gesto do artesão que muito podem contribuir para entender aspectos da dinâmica social. A remontagem da cadeia operatória possibilitou conhecer as possibilidades e limitações do material e com isso, controlar melhor as etapas de produção, desde a escolha de materiais adequados para construção de uma peça, bem como os instrumentos e as intenções de decoração até os efeitos de queima e pós-queima inerentes ao fazer cerâmico.

A partir das análises de vestígios químicos realizada na Universidad Nacional Autónoma de México (UNAM) foi possível identificar perguntas sobre a utilização do material. No entanto, o número reduzido de fragmentos investigados nessa análise que tinha tanto um caráter preliminar, como de capacitação, não permitiu afirmar um uso específico com certeza ou mesmo construir um mapa de ocupação do sítio. Dessa forma, os resultados ficaram restritos a fragmentos sem uma coerência espacial, mas sim, priorizando a diversidade tecnológica.

Já as análises de fluorescência de raios-X com pigmento e pasta cerâmica permitiram confirmar resultados do trabalho de experimentação, como a utilização do pigmento pré-queima e pastas cerâmicas diferentes encontradas no mesmo sítio. Além disso, a comparação com os índices de vestígios químicos permitiu elaborar hipóteses sobre a utilização dos potes cerâmicos. As análises dos espectros de raios-X não foram esgotadas, mas evidenciaram que ocorrem diferenças entre pigmente e pasta e essas diferenças merecem ser exploradas em outro momento. 
O fluxograma (figura 5.1) representa a cadeia operatória deduzida para a cerâmica do sítio Gramado. As letras D em vermelha indicam etapas onde ocorreram grandes escolhas do artesão. Das primeiras fases da cadeia operatória entendeu-se que a seleção da matéria prima (argila) e a definição de forma dos potes dependem de decisões do oleiro. Essas decisões estão ligadas a diversos fatores, como: qualidade do barro (impurezas), presença intencional ou não de antiplástico (mineral, caco moído, carvão ou cariapé), fontes de argila próximas ou não do sítio. No que dizem respeito à forma dos potes, estas estão ligadas principalmente com suas funções.

A confecção dos roletes não foi entendida como uma escolha do artesão porque não foram encontradas formas diferentes de construção de um pote. Isso sugere que era a única técnica conhecida. É possível que o modelamento fosse utilizado, mas ele não apareceu. Ausências de peças não são evidências em si, mas são provas importantes de que uma técnica não era dominada ou usual.

A junção de roletes como tratamento de superfície foi considerada uma escolha entre: alisamento interno e decoração corrugada na parte externa ou alisamento interno e externo para aplicação de pigmentos. As cerâmicas pintadas podem ou não apresentar brunidura, dependendo da intenção de acabamento e uso.

A secagem é um processo da cadeia operatória que não depende da decisão do artesão, mas sim da temperatura e umidade ambiental e da quantidade de água presente na argila. $\mathrm{O}$ oleiro pode amenizar o tempo de secagem utilizando pouca água durante a confecção do objeto, mas não pode controlar totalmente essa etapa. Os defeitos que aparecem durante essa etapa são provenientes de falhas de alisamento e por tentativa de acelerar a secagem expondo a peça ao sol ou em temperaturas muito elevadas.

O tipo de cozedura e temperatura são razoavelmente controlados pelo artesão. Uma queima que ocorre elevação de temperatura muito rápida pode ocasionar deformações e quebra da peça cerâmica. A quantia de lenha, sua umidade, o tipo de madeira e a fonte da fogueira também influenciarão nas características da cerâmica: como cozimento, textura, dureza e coloração interna. Esses diversos fatores influenciam no resultado final, pela quantidade de energia gerada e oxigênio disponível, que pode implicar em queima redutora. Faz parte da queima o processo de resfriamento da peça que acontece dentro do forno, caso contrário a peça pode sofrer um choque térmico. Muitos objetos estouram durante a queima porque a etapa de preparação de argila e eliminação de bolhas não foi bem feita e isso leva a uma decisão de descarte sem uso, ou uso como caco moído (antiplástico). 
As peças quebradas durante o processo da cadeia operatória, bem como aquelas descartadas por tempo de uso são incorporadas ao substrato, passam pelo processo tafonômico e transformam-se em material arqueológico.

\section{Perpectivas para o futuro}

Considerando todo o exposto acima, aparecem alguns aspectos que merecem exploração e que podem pesquisados em trabalho futuros:

- um aspecto que merece estudo aprofundado é a condição de queima (queima oxidante/redutora): seria interessante detalhar em que condições uma cerâmica fica totalmente oxidada e em que condições fica com medula escura; relacionar a espessura da peça, disponibilidade de oxigênio, temperatura e tempo de queima num modelo experimental, ajudaria muito as interpretações arqueológicas;

- também seria relevante relacionar as análises de vestígios químicos com a topologia do sítio. Os vestígios químicos podem ser pistas importantes sobre o uso das peças e podem revelar características das moradias, usos e funções, bem como aspectos culturais, comportamentais e rituais;

- análises de fluorescência de raios-X podem ser aplicadas às argilas brutas da região, às fontes de argila próximas ao sítio e às cerâmicas arqueológicas, para compreender melhor as fontes de busca, as técnicas de preparação e a dinâmica da indústria (busca de matériaprima, distância de prospecção, trocas entre grupos);

- uma característica que foi pouco explorada nesta pesquisa foi o antiplástico; seria importante entender a composição original da pasta e a incorporação de antiplástico usando análises arqueométricas e análises pouco usuais, como análises microscópicas mineralógicas e botânicas, de forma a avaliar quantitativamente e qualitativamente os antiplásticos;

- outros aspectos a explorar são as características físicas da cerâmica, como dureza, densidade, resistência à compressão, abrasão e flexão, de forma a avaliar objetivamente a qualidade do cozimento (sinterização) e da pasta (teor de álcalis). Esses caracteres poderiam ser cruzados com as pesquisas de queima controlada de forma a fornecer uma visão ampla e detalhada do domínio das propriedades e técnicas cerâmicas pelos tupiguarani ;

- por fim, seria importante correlacionar matematicamente aspectos artísticos, como pintura (engobo), decoração plástica, com aspectos técnicos como dureza, espessura, sinterização bem como vestígios químicos, de forma a desenvolver um modelo amplo e detalhado da indústria, expertise e uso da cerâmica tupiguarani. 


\section{Conclusão}

As análises e discussões dessa dissertação apresentaram aspectos tecnológicos e estilísticos da cerâmica do sítio Gramado, bem como elencaram hipóteses sobre sua utilização:

- Constatou-se a presença de número elevado de cerâmica em superfície e sub-superfície, além de focos de concentração de material em duas áreas. Uma das áreas consistia em local onde foi encontrada a urna funerária.

- A visita ao sítio Gramado, quinze anos após a etapa de campo, comprovou ainda a presença de muita cerâmica em superfície, fato que demonstra a importância de novos trabalhos na região;

- A partir das características estilísticas da cerâmica do sítio Gramado pôde-se associá-lo à tradição Tupiguarani: fundo branco, faixa vermelha e linhas pretas retas, curvas e obliquas;

- A técnica de confecção da cerâmica é o acordelado;

- A maioria dos fragmentos apresentou quebra no rolete causado pelo alisamento ruim;

- Os fragmentos de parede representam o maior número, seguidos de bordas e bases;

- Entre os tipos decorativos, a decoração plástica corrugada é a mais freqüente.

- A decoração corrugada provavelmente ocorreu a partir da utilização do dedo e no momento de união dos roletes. Algumas decorações mostraram-se impossíveis de serem feitas com a mão, como é o caso do corrugado-espatulado;

- O corrugado tem uma função importante de junção dos roletes, mas também deve ser uma escolha estilística;

- A utilização de fragmentos de madeira e bambu mostrou-se eficientes na confecção da decoração corrugada permitindo maior domínio de forma e simetria;

- Os tipos decorativos plásticos: corrugado e ungulado sugerem que ocorreu uma pesquisa pelo artesão ou grupo sobre os instrumentos para sua melhor confecção;

- A experimentação com de óxido de ferro indicou que o pigmento não permanece na peça cerâmica quando já queimada;

- A pintura consistiu em aplicar engobo no momento em que a argila está no ponto de couro e antes da queima;

- A escolha da técnica do engobo sugere que o artesão conhecia bem o fazer cerâmico; 
- As análises de fluorescência de raios-X indicaram que o pigmento branco era de origem mineral (silicato) e resistente a queima, com isso reforça-se a idéia de se tratar de pintura realizada antes da cozedura;

- As análises de vestígios químicos mostraram que algumas bordas com decoração pintada apresentaram maior concentração de fosfato e, também alto índice de resíduos protéicos, o que indica a presença de alguns ou dos três elementos: carne, ossos ou sangue;

- As peças que sofreram aceleração no processo de secagem, racharam ou quebraram. Isso permite concluir que as etapas da cadeia operatória seguem regras rígidas, caso contrário ocorre perda de material e tempo;

- A coloração da cerâmica indicou tratar-se de queima rápida e com pouco oxigênio;

- A análise conjunta de vestígios químicos e fluorescência de raios-x permitiu identificar a presença de fragmento em que a pasta cerâmica possuía elementos constitutivos diferentes dos demais.

- Ocorreram escolhas diferentes de fonte de argila ou presença de fragmentos trazidos de outros lugares.

Considerando todo o exposto nesta dissertação, considero que a hipótese formulada foi corroborada pelos resultados e pela argumentação apresentada, de forma que de fato há evidências de que o estudo do gesto permite conhecer aspectos comportamentais de uma sociedade. 


\section{Bibliografia}

AFONSO, M. C. ; MORAES, C. A. O Sítio Água Branca: interações culturais dos grupos ceramistas no norte do Estado de São Paulo. Revista do Museu de Arqueologia e Etnologia, v. 15-16, p. 59-71, 2006.

AFONSO, M. C. Um Olhar para a Arqueologia Pré-Histórica do Estado de São Paulo. 2005. Tese (Livre docência em Arqueologia) - Museu de Arqueologia e Etnologia, Universidade de São Paulo, São Paulo, 2005.

AFONSO, M. C. Uma abordagem da ocupação do território paulista. In: IX Congresso da Sociedade de Arqueologia Brasileira, 1997, Rio de Janeiro. Congresso da Sociedade de Arqueologia Brasileira, IX. Resumos.. Rio de Janeiro: Sociedade de Arqueologia Brasileira (SAB), 1997.

ALVES, M.A.; CALLEFFO, M.E.V. Sítio de Água Limpa, Monte Alto, São Paulo - estruturas de combustão, restos alimentares e padrões de subsistência. Revista do Museu de Arqueologia e Etnologia, São Paulo, v.6, p.123-140, 1996.

AMENOMORI S. N. Paisagem das ilhas, as ilhas da paisagem: a ocupação dos grupos pescadores-coletores pré-históricos no litoral norte do Estado de São Paulo. 2005. .Dissertação (Mestrado em Arqueologia), Museu de Arqueologia e Etnologia, Universidade de São Paulo, São Paulo.2005

APPOLONI, C. R. Material da disciplina de pós-gradução Técnicas atômico-nucleares não destrutivas aplicadas a objetos de arte, 2008. Realizada no Museu de Arqueologia e Etnologia da Universidade de São Paulo, São Paulo, 2008.

APPOLONI, C. R., BLONSKI, M. S., PARREIRA, P. S., SOUZA, L. A. C. Study of the pigments elementary chemical composition of a painting in process of attribution to Gainsborough employing a portable X-rays fluorescence system. Nuclear Instruments \& Methods in Physics Research A., v.580, p.710 - 713, 2007.

APPOLONI, C. R., PARREIRA, P. S. Doze anos de atividades em arte e arqueometria no Laboratório de física nuclear aplicada da Universidade Estadual de Londrina. Revista brasileira de Arqueometria, Restauração e Conservação. , v.01, p.301-304, 2007.

APPOLONI, C. R., PARREIRA, P. S., RIZZO, M. Aplicação de um equipamento portátil de EDXRF no acompanhamento dos trabalhos de restauro de pinturas murais na Igreja da Paróquia Imaculada Conceição (São Paulo/SP). Revista brasileira de Arqueometria, Restauração e Conservação, v.01, p.161-164, 2007.

APPOLONI, C. R., QUINONES, F. R. E., ARAGÃO, P. H. A., SANTOS, A. O. dos, SILVA, L.M. da, BARBIERE P.F., NASCIMENTO FILHO, V.F. Do, COIMBRA, M.M. EDXRF study of Tupi-Guarani archaeological ceramics. Radiation Physics and Chemistry, v.61, p.711-712, 2001.

APPOLONI, C. R.; PARREIRA, P. S.; SOUZA, E de; QUACCHIA, J. C. A.; NASCIMENTO FILHO, V. F. do; GIGANTE, G. E.; CESAREO, R.; CUNHA e SILVA, R. M. da. Estudo 
de cerâmicas arqueológicas do Paraná por técnicas nucleares não-destrutivas. Revista do Museu de Arqueologia e Etnologia da Universidade de São Paulo, v. 2, p. 135-149, 1997.

ARAÚJO, A. G. M. Levantamento Arqueológico da Área Alto Taquari, Estado de Sâo Paulo, com Ênfase na Abordagem dos Sítios Líticos. 1995. Tese (Mestrado em Arqueologia) Museu de Arqueologia e Etnologia, Universidade de São Paulo, São Paulo, 1995.

ARAÚJO, A. G. M. Teoria e Método em Arqueologia Regional: Um Estudo de Caso no Alto Paranapanema, Estado de São Paulo. 2001. Tese (Doutorado em Arqueologia) - Museu de Arqueologia e Etnologia, Universidade de São Paulo, São Paulo, 2001.

ARRHENIUS, O. Investigation of soil from old Indian sites. Ethnos, v. 2-4, p.122-136.1963

AYTAI, D. Um estilo de decoração tupi: ordem no caos. Publicações do Museu Municipal de Paulínia: Humanitas, São Paulo, v. 48, p. 22-35, 1991.

BAKKEVIG, S. Phosphate Analysis in Archeology: Problems and Recent Progress, Norweig Archaelogical Review, Oslo, v.13, n. 2, p. 73-100, 1980.

BALFET, H. Observer l'action technique: des chaines operatoires, pour quoi faire? Paris: CNRS Editions, 1991. 191p.

BARBA L. e MEJÍA-PEREZ, E. El análisis en al arqueologia: historia e perspectivas. Mexico DF: Instituto de Investigaciones Antropologicas, UNAM. 1994.

BARBA, L. e LAZOS, L. Chemical Analysis of Floors for the Identification of Activity Areas: A Review, Antropología y Técnica, n. 6, p. 59-70. 2000.

BARBA, L. e MANZANILLA, L. Estudio de areas de actividad. In: Manzanilla, L. (Ed.), Cobá, Quintana Roo: Análisis de dos Unidades Habitacionales Mayas. México: Universidad Autónoma de México. 1987. p. 69-115.

BARBA, L. e ORTIZ, A. Análisis químico de pisos de ocupación: un caso etnográfico en Tlaxcala, México. Latin American Antiquity, v.3 n.1, p. 63-82, 1992.

BARBA, L., e BELlO G. Análisis de Fosfatos en el Piso de una Casa Habitada Actualmente”, Notas Antropológicas, v.1, n. 24, p.188-193. 1978.

BARBA, L.; RODRIGUEZ, R.; CÓRDOBA, J. L. Manual de técnicas microquímicas de campo para la arqueologia. Mexico DF: Instituto de Investigaciones Antropologicas, UNAM, 1991.

BARBA, P. e TOVALIN, L. A. Estudio de las unidades habitacionales antes de la excavación, in Cobá, Quintana Roo. In: Manzanilla, L. (Ed.), Cobá, Quintana Roo: Análisis de dos Unidades Habitacionales Mayas. México: Universidad Autónoma de México. 1987. p. 332-337.

BEDOUCHA, G. The watch and the waterclock: technological choices/social choices. In LEMONNIER, P. Technological Choices: Transformation in Material Cultures since the Neolithic. London: Routledge, 2002. p. 77-107.

BOAS, F. Arte primitiva. Nova York: Dover Publications, 1955. 
BROCHADO, J. P. A tradição cerâmica Tupiguarani na América do Sul. Clio, Série Arqueológica, v.3, 117-164, 1981.

BUENO, F. da S. Vocabulário Tupi-Guarani-Português. $2^{\mathrm{a}}$ edição. São Paulo: Editora Gráfica Nagy Ltda. 1993.

CALDARELli, S. B. Aldeias Tupiguarani no vale do rio Mogi-Guaçu, Estado de São Paulo. Revista de Pré-História IPH-USP, São Paulo, v. 5, p. 37-124, 1983.

CALDARELli, S. B. e NEVES, W. A. Programa de Pesquisas Arqueológicas no Vale do Rio Pardo. Revista de Pré-história IPH-USP, São Paulo, v. 3, p. 13-49,1982.

CAÑABATE, M. L. e VIZCAÍNO, A. Análisis de indicadores bioquímicos del contenido de recipientes arqueológicos. Complutum, v.6, p. 281-291, 1995.

CAÑABATE, M. L. e VIZCAÍNO, A. Indicadores químicos para la arqueología. Jaen: Centro Andaluz de Arqueologia Ibérica, Universidad de Jaen, Espanha, 1998. p 59-115.

CASSON, M. Alfarería Artesana. 2ª Ed. Barcelona: Edições CEAC, 1991. 128p.

CASTRO, P. R. M. A História de Brotas, em: <http://www.vemprabrotas.com.br/ pcastro/brotas.htm>. 1997. Acesso: março/2011.

CEREZER, J. F. Revendo problemáticas, traçando perspectivas: contributo da arqueologia experimental para a cerâmica guarani. Dissertação (Master erasmus Mundus em Quaternário e Pré-História) - Instituto Politécnico de Tomar, Universidade de Trás-osmontes e Alto Douro, Departamento de Território Arqueologia e Patrimônio do IPT. 2009

CHAVARRIA, J. Modelagem. Tradução de Joana Ferreira da Silva. Lisboa: Editorial Estampa, 1999. 63p.

CHMYZ, I. Terminologia arqueológica brasileira para a cerâmica. Cadernos de arqueologia, v.1, n.1, Paranaguá: Universidade Federal do Paraná, 1976.

COLES, J. Arqueologia Experimental. Lisboa: Editora Bertrand. 1973.

CONDAMIN, J.; FORMETTI, F.; METAIS M. O.; MICHEL, M.; BLOND P. The Application of gas chromatography to the tracing of oil in ancient amphorae. Archaeometry, v. 18, p.195-201, 1976.

CRESSWELL, R. Of mils and waterwheels: The hidden parameters os tecnological choice. In LEMONNIER, P. Technological Choices: Transformation in Material Cultures since the Neolithic. London: Routledge, 2002. P. 181-213

EIDT, R.C. Detection and examination of anthrosols by phosphate analysis. Science, v. 197, p. 1327-1333, 1977.

EVERSHED, R. P.; HERON, C.; GOAD, L. J. Analysis of organic residues of archaeological origin by high temperature gas chromatography/mass spectrometry. Analyst, v. 115, p. 1339-1342, 1990. 
FACCIO, N. B. Arqueologia dos cenários das ocupações horticultoras da Capivara, Baixo Paranapanema. 1998. Tese (Doutorado em Arqueologia) - Faculdade de Filosofia, Letras e Ciências Humanas, Universidade de São Paulo, São Paulo. 1998.

FACCIO, N.B. Estudo do sítio arqueológico Alvim no contexto do Projeto Paranapanema. 1992. Dissertação (Mestrado em Arqueologia) - Faculdade de Filosofia, Letras e Ciências Humanas, Universidade de São Paulo, São Paulo. 1992.

FEIGL, F. e ANGER, V. Spot Tests in Organic Analysis. 7a Ed. New York: Elsevier Publ. Co., 1958.

FERNANDES, S.C.G. Estudo tecnotipológico da cultura material das populações pré-históricas do Vale do rio Turvo, Monte Alto, SP e a tradição Aratu-Sapucaí. 2001 Dissertação (Mestrado em Arqueologia) - Faculdade de Filosofia, Letras e Ciências humanas, Universidade de São Paulo, São Paulo, 2001.

GOMES, D. Cerâmica arqueológica da Amazônia: vasilhas da coleção Tapajônica MAE/USP, São Paulo: Editora da Universidade de São Paulo-Fapesp-Imprensa Oficial do Estado. 2002. 355p.

HANSELI, F. A.; FOSSARI, T. D.; MADUREIRA, L. A.dos S. Lipídios em sedimentos arqueológicos - resultados preliminares do sítio arqueológico Rio do Meio, Ilha de Santa Catarina (SC).Revista Brasileira de Ciência do Solo v..32 n.1, Viçosa, 2008.

HERON, A. e EVERSHED, R. P. The analysis of organic residues and the study of pottery use. Schiffer, M.B. (ed): Archaeological method and theory, vol 5: 247-284. Tucson: University of Arizona Press, 1993.

IBGE 2010. Mapa de divisões territoriais, em: <http://mapas.ibge.gov.br/divisao/viewer.htm> Acesso diversas vezes em 2010 e 2011.

KINGERY, B. U.; BOWEN, H. K. e UHIMANN, D. R. Introduction ceramics. 2 Ed. New York: Wiley-Interscience, 1976. $1056 \mathrm{p}$.

LA SAlVIA, F. \& BROCHADO, J. P. Cerâmica Guarani. Porto Alegre: Posenato Arte \& Cultura, 1989. 175p.

LEEW, S. van der. Giving de potter a choice: Conceptual aspects of pottery techniques. In LEMONNIER, P. Technological Choices: Transformation in Material Cultures since the Neolithic. London: Routledge, 2002. P. 238-288.

LEMONIER, P. Technological Choices: Transformation in Material Cultures since the Neolithic. London: Routledge. 2002.

LEROI-GOURHAN, A. (1943) O gesto e a palavra 1 - Técnicas e Linguagem. Coleção Perspectivas do Homem. Lisboa: Edições 70, 1990. 237p.

LEROI-GOURHAN, A. Évolution et techniques: L'homme et La matière. Paris: Albin Michel, 1943. 
LIVINGSTONE-SMITH, A. Reconstitution de La chaîne opératoire de la poterie - Bilan et perspectives en Afrique sub-saharienne. Les Nouvelles de L'archéologie, v. 119, 2010.

MARANCA, S.; SILVA, A. e SCABELlO, A. M. Projeto Oeste Paulista de arqueologia do Baixo e Médio vale do rio Tietê: síntese dos trabalhos realizados. Revista do Museu de Arqueologia e Etnologia, São Paulo, v. 4, p. 223-226. 1994.

MATISSON, S. Guía Completo del ceramista - herramientas, materiales y técnicas. Tradução Cristina Rodríguez Fischer. Barcelona: Blume, 2004. 224p.

MAUSS, M. (1950) Técnicas e movimentos corporais. In: Sociologia e Antropologia, volume II, São Paulo: EDUSP, 1974.

MAUSS, M. As técnicas corporais In: Sociologia e Antropologia. Tradução de Lamberto Puccinelli. São Paulo: EPU, 1974. 331p.

MEGGERS, B. J. e EVANS, C. Como interpretart a linguagem da cerâmica: manual para arqueólogos. Tradução de Alroino B. Eble. Washington DC: Smithsonian Institution, 1970. $111 \mathrm{p}$.

MEJÍA-PEREZ, E. e BARBA, L. El análisis de fosfatos en la arqueología: historia y perspectivas. Anales de Antropología, v.25, p. 127-147. 1988

MILLER, T.O. Arqueologia da região central do Estado de São Paulo. Dédalo. São Paulo, v. 8 n.16, p. 13-118, 1972.

MORAES, C. A. Arqueologia Tupi no nordeste de São Paulo: um estudo da variabilidade artefatual. 2008. Dissertação (Mestrado em Arqueologia), Museu de Arqueologia e Etnologia, Universidade de São Paulo, São Paulo. 2007.

MORAIS, J. L. Arqueologia da região Sudeste. Revista da USP, v. 44, p. 194-217, 1999/2000.

MORAIS, J. L. Projeto Paranapanema: Programa de pesquisas arqueológicas da bacia do Paranapanema, Estado de São Paulo. Dossiê 1968-1988, v 4. 1999.

MORAIS, J. L. Salvamento Arqueológico na área de influência da PCH Moji-Guaçu. (Projeto) São Paulo: MAE-USP, 1985.

NOELLI, F. S. José Proenza Brochado: Vida acadêmica e a Arqueologia Tupi. In: PROUS, A. e LIMA, T. A. (Eds). Os Ceramistas Tupiguarani. V. 1 - Sínteses regionais. Belo Horizonte: Sigma, 2008. p 17-39.

ORTIZ, A. Estudio químico de un conjunto residencial teotihuacano. Tese (Doutorado), Escuela Nacional de Antropologia e História. México DF 1990.

PALlESTRINI, L. 1981 Cerâmica há 1500 anos, Mogi-Guaçu, São Paulo. Revista do Museu Paulista, São Paulo, v. 28, p. 115-129.

PANACHUK, L. Os gestos da produção de particularidade no universo cerâmico Tupiguarani (Sítio Ibiporã-1, norte do Paraná). In: Encontro do Núcleo Regional da SAB Sul, V, 2006. Resumos do V Encontro do Núcleo Regional da SAB Sul. Rio Grande: SAB, 2006. CD. 
PATRICK, M.; SMITH., A. B. e KONING, A. J. Gas-liquid chromatographic analysis of fatty acids in food residues from ceramics found in the south-western Cape, South Africa. Archaeometry, v. 27, p. 231-246, 1985

PAZ, O. O uso e a contemplação. Revista Raiz, v.3, 2006.

PECCI, A.; ORTIZ, A.; BARBA, L. e MANZANILLA, L.R. Distribución espacial de las actividades humanas con base en el análisis químico de los pisos de Teopancazco, Teotihuacan. In: Coloquio Pedro Bosch Gimpera, VI, 2010, Cidade do México. Memorias del VI Coloquio Pedro Bosch Gimpera: Lugar, espacio y paisaje en arqueología: Mesoamérica y otras áreas culturales. Mexico DF: Editora Ortiz Díaz-UNAM. Publicación electrónica del IIA,. 2010. P. 447-472.

PÉREZ, R. M., BARBA, L. Pruebas químicas y áreas de actividad en contextos domésticos del norte del área maya. Un análisis comparativo. In Congreso Internacional de Mayistas, III, 2002, Chetumal. Memoria del III Congreso Internacional de Mayistas vol. 2, Chetumal: IIE-UNAM-Universidad de Quintana Roo. 2002.

PROSCH-DANIELSEN, L. e SIMONSEN, A. Principal components analysis of pollen, charcoal and soil phosphate data as a tool in prehistoric land-use investigation at Forsandmoen, southwest Norway. Norwegian Archaeological Review, v. 21, p. 85-102. 1989

PROUS, A. Arqueologia Brasileira. Brasília: Editora Universidade de Brasília. 1992.

PROUS, A. Arte pré-histórica do Brasil. São Paulo: Editora Com-Arte, 2007. 125 p.

PROUS, A. O Brasil antes dos Brasileiros - A pré-história do nosso país. Rio de Janeiro: Jorge Zahar Editor, 2006. 140 p.

PROUS, A.; ALONSO, M.; PILÓ, H.; XAVIER, L. A. F.; LIMA., A. P. e SOUZA, G. N. Os machados pré-históricos no Brasil. Descrição de coleções brasileiras e trabalhos experimentais: fabricação de laminas, cabos, encabamento e utilização. Revista Canindé, v. 2, p. 161-236. 2000.

QUILICI-PACAUD, J. F. Dominant representations and technical choices: A method os analysis with examples from aeronautics. IN: LEMONIER, P. Technological Choices: Transformation in Material Cultures since the Neolithic. London: Routledge. 2002. p. 339412

RHODES, D. Hornos para ceramistas. Barcelona: Editora CEAC, 1987. 287p.

RIBEIRO, B. G. Arte Indígena - Linguagem Visual. São Paulo: Editora da Universidade de São Paulo, 1989. 185p.

ROBRAHN-GONZALEZ, E. M. Repensando as fronteiras culturais de grupos ceramistas no Estado de São Paulo. Congresso da Sociedade de Arqueologia Brasileira, XIII, 2003. Resumos. XIII Congresso da Sociedade de Arqueologia Brasileira, São Paulo. p 175. 2003.

ROBRAHN-GONZALEZ, E. M., Os grupos ceramistas pré-coloniais do Brasil Central: Origens e desenvolvimento. 1996. Tese (Doutorado em Arqueologia) - Faculdade de Filosofia, Letras e Ciências Humanas, Universidade de São Paulo, São Paulo. 1996. 
RODRIGUES, R. A. e AFONSO, M. C. Um olhar etnoarqueológico para a ocupação guarani no Estado de São Paulo. Horizontes Antropológicos, Porto Alegre, Rio Grande do Sul, v. 18, p. 155-174, 2002.

RYE, O. S. Pottery technology. Principles and reconstruction. Manuals on Archaeology 4, Washington DC: Smithsonian Inst. Press, 1981.

SCATAMACCHIA, M. C. M. Ocupação Tupi-guarani no Estado de São Paulo: Fontes EtnoHistóricas e Arqueológicas. Dédalo, São Paulo, v. 23, p. 197-222, 1984.

SCATAMACCHIA, M. C. M. Tentativa de caracterização da tradição Tupiguarani. Dissertação (Mestrado em Arqueologia), Faculdade de Filosofia, Letras e Ciências Humanas, Universidade de São Paulo, São Paulo. 1981.

SILVA, F. A. As tecnologias e seus significado: um estudo da cerâmica dos Assurini do Xingu e da cestaria dos Kaiapó-Xikrin sob uma pesrpectiva etnoarqueológica.. 2000 Tese (Doutorado em Arqueologia) - Faculdade de Filosofia, Letras e Ciências Humanas, Universidade de São Paulo, São Paulo. 2000.

SILVA, R. M. da C.; NASCIMENTO FILHO, V. F. do; APPOLONI, C. R.; PEREZ, C. A. Fluorescência de Raios-X aplicada a amostras arqueológicas. Revista do Museu de Arqueologia e Etnologia, v.15/16, p.371-382. 2005.

SKIBO, J. M. e SCHIFFER, M. B. People and Things - A behavioral aprroach to material culture. New York: Springer, 2008.

SKIBO, J. M. Pottery Function: A Use-Alteration Perspective - Interdisciplinary Contributions to Archaeology. USA Plenum Press. 1992.

SOUZA, G. N. de. O material lítico polido do interior de Minas Gerais e São Paulo: entre a matéria e a cultura. 2008. Dissertação (Mestrado Arqueologia) - Museu de Arqueologia e Etnologia, Universidade de São Paulo, São Paulo. 2008.

SUZE, S. Os guarani e a redução jesuítica: tradição e mudança técnica na cadeia operatória de confecção dos artefatos cerâmicos do sítio Pedra Grande e entorno. Dissertação (Mestrado em Arqueologia), Museu de Arqueologia e Etnologia, Universidade de São Paulo, São Paulo. 2009.

VIDAL, L. Grafismo Indígena: estudos de antropologia estética. São Paulo: Studio NobelEditora da Universidade de São Paulo-FAPESP, 1992.

VINBERG, A. Phosphates - The Invisible Garbage. Archaeological excavations Depto. The Hägersten; Swedish National Heritage Board. 1990. 30 p.

VITELLI, K. looking upa t early ceramics in Greece. In SKIBO, J. M. e SCHIFFER, M. B. (Eds.) Pottery and people; a dynamic interaction. New York: Springer, 1999. p.184-198

ZANETTINI, P. E. Maloqueiros e seus palácios de barro : o cotidiano doméstico na Casa Bandeirista. 2005. Tese (Doutorado em Arqueologia) - Museu de Arqueologia e Etnologia, Universidade de São Paulo, São Paulo, 2005. 413p. 
